\title{
مدى تطبيق مدراء المدارس الحكومية لدور المشرف المقيم في مدارسهم من وجهة نظر مدراء المدارس لارس المشرف انفسهر
}

هدفت هذه الدر اسة للتعرف إلى مدى تطبيق مدر اء المدارس الحكوميـة لدور المشرف المقيم في مدارسـهم من وجهة نظر مدر اء المدارس انفسهم ، استخدم الباحث المنهج الوصفي في الدراسـة. وتكون مجتمع الدر اسـة من جميع المدر اء العاملين في وزارة التربية والتعليم الاردنية. وقد تم اختيار عينة عثـائية لتمثيل مجتمع الدر اسـة، حيث بلغت نسبة العينة ما يقارب (30\%) من مجتمع الدر اسة. واستخدم الباحث بتوظيف أداة الاستبانة لتحقيق

$$
\text { أهداف الدر اسة حيث تكونت من (30) فقرة. }
$$

وقد أظهرت نتائج الدر اسة أن مدى درجة تطبيق دور المشرف المقيم لدى المدر اء في مدارسـهم من وجهة نظر المدر اء انفسهم جاء" قليلاً" كما أشارت النتائج إلى وجود فروق ذات دلالة إحصائية تعزى لمتغير جنس المدرسة

$$
\text { لصالح مدارس الإناث مقارنة بمدارس الذكور. }
$$

وخلصت الدر اسة لعدم وجود فروق ذات دلالة إحصائية لمدى تو افر المهار ات الاشر افية لدى المشرف المقيم في مدارسـهم من وجهة نظر المدر اء انفسـهم تعزى لمتغيرات الدر اسـة الاخرى(الجنس، سـوات الخبرة، الدرجـة العلمية) وان درجة تطبيق المدراء لادوار هم كمشرفين مقيمين هي قليلة. 


\begin{tabular}{|c|c|c|c|}
\hline 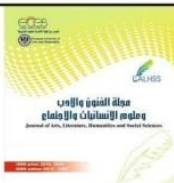 & 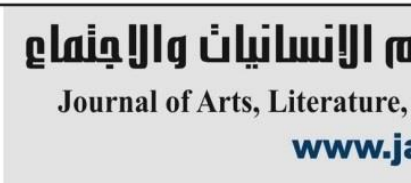 & $\begin{array}{l}\text { n } \\
\text { and Social Sciences } \\
\text { n }\end{array}$ & \\
\hline$==$ & Volume (71) September 2021 & العدد(71) سبتمبر 2021 & \\
\hline
\end{tabular}

\title{
The Extent to Which Government School Principals Apply The Role of The Resident Supervisor in Their Schools from The Point of View of School Principals Themselves
}

\author{
Amal Sami Karim Khasawneh \\ Jordanian Ministry of Education \\ Email: abdkh111@gmail.com
}

\begin{abstract}
This study aimed to identify the extent to which government school principals apply the role of the resident supervisor in their schools from the point of view of school principals themselves. The researcher used the descriptive approach in the study. The study population consisted of all principals working in the Jordanian Ministry of Education. A random sample was chosen to represent the study population, as the sample percentage was approximately $(30 \%)$ of the study population. The researcher used a questionnaire tool to achieve the objectives of the study, which consisted of (30) items.

The results of the study showed that the degree of application of the role of the resident supervisor among principals in the schools of the school from the point of view of the principals themselves was "little", and the results indicated that there were statistically significant differences due to the variable of school gender in favor of female schools compared to male schools.

The study concluded that there are no statistically significant differences in the availability of supervisory skills for the resident supervisor in their schools from the point of view of the principals themselves due to the other variables of the study (gender, years of experience, academic degree) and that the degree of principals' application of their roles as resident supervisors is few.
\end{abstract}

Keywords: school principals, resident supervisor, Jordanian Ministry of Education. 


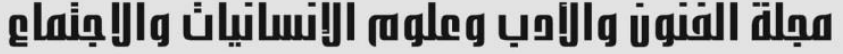

Journal of Arts, Literature, Humanities and Social Sciences www.jalhss.com

المقدمة:

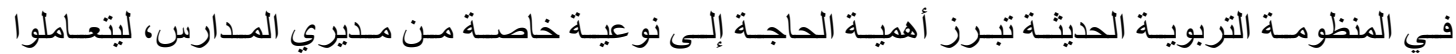

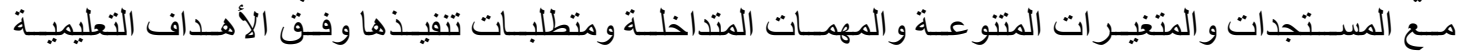

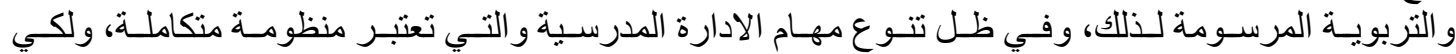

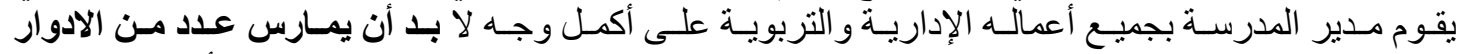

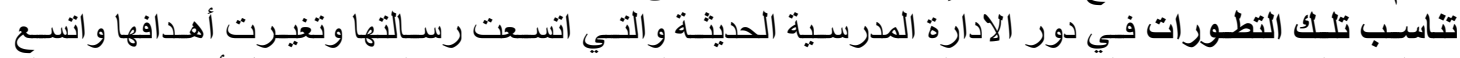

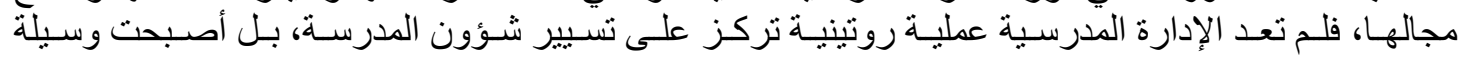

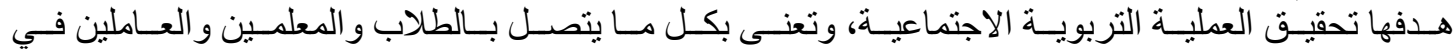

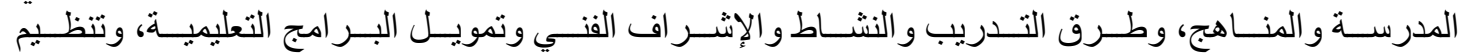

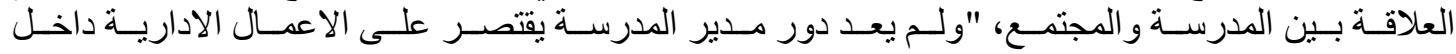

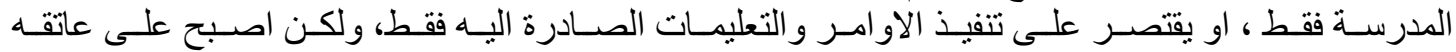

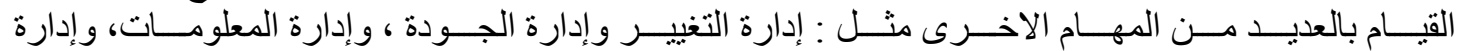

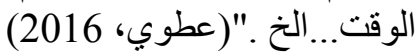

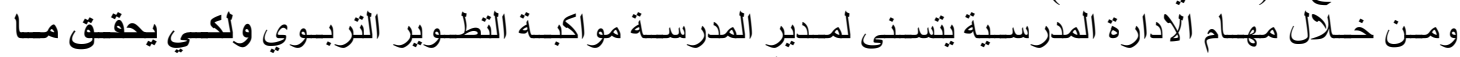

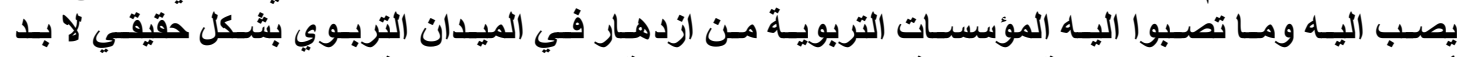

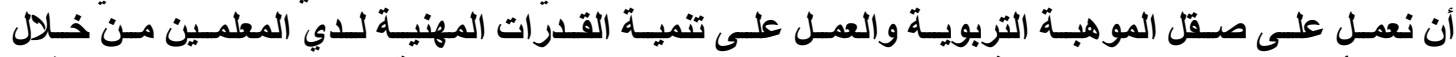

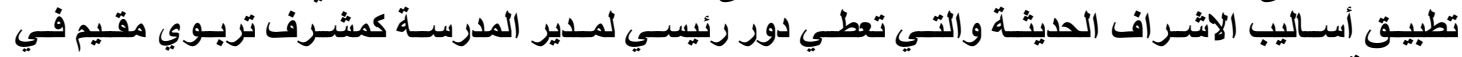
المدرسةة.

مشكلة الار اسة وأسئلتها

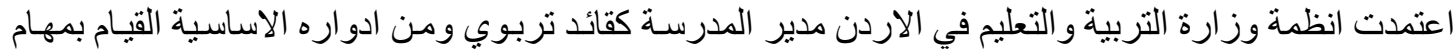

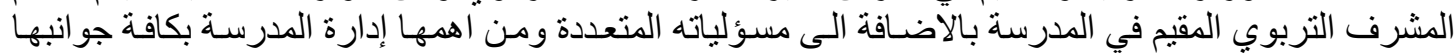

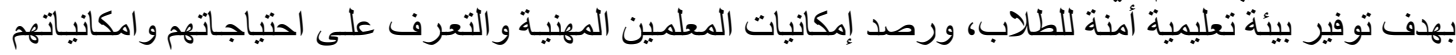

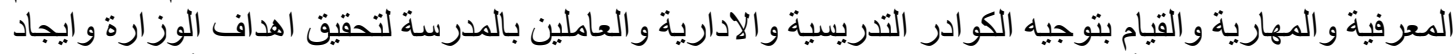

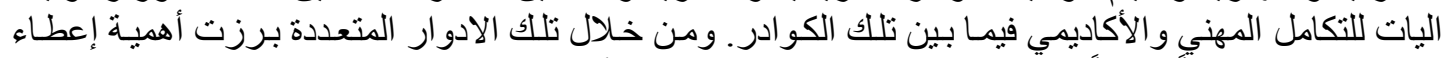

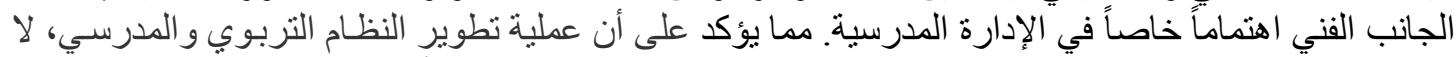

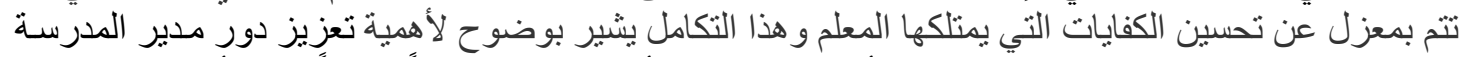

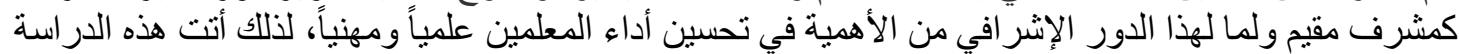

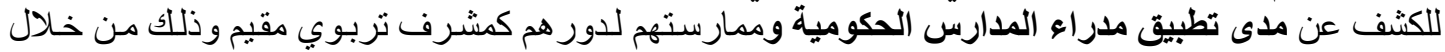
الإجابة عن الأسئلة الآتية:

1- ما مدى تطبيق مدراء المدارس الحكومية لمهامهم الإشر افية من وجهة نظر المدر اء انفسهم في الأردن؟

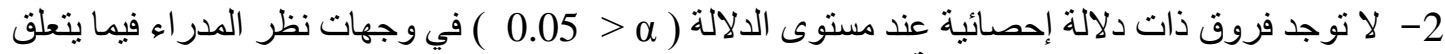

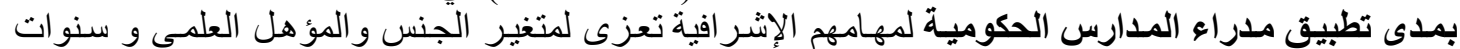
الخبرة

$$
\text { أهداف الدر اسةة هذه الدراسة إلى: }
$$

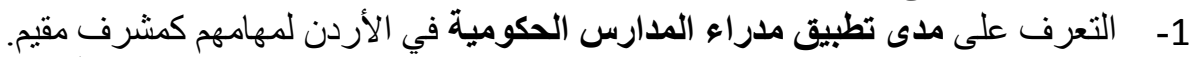

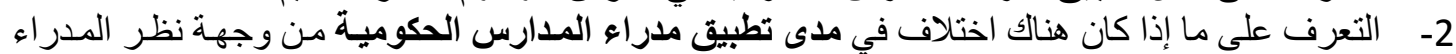
انفسهم تعزى لمتغير ات الدر اسة.

$$
\text { أهمية الدراسة: أهمية هذه الدر اسة في الأتي: }
$$




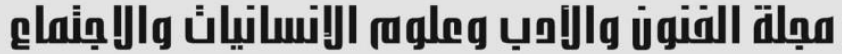

Journal of Arts, Literature, Humanities and Social Sciences www.jalhss.com

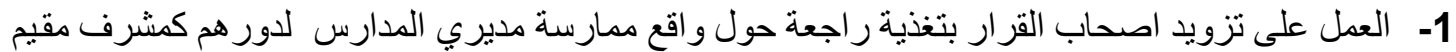

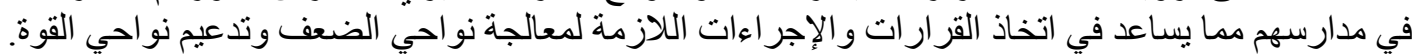

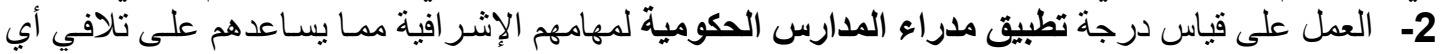
قصور في ممارساتهم.

فرضيات الار اسة: حاولت الدراسة فحص الفرضية الفرضية الصفرية التالية

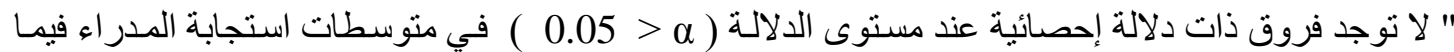
يتعلق بمدى تطبيق مدراء المدارس الحكومية بصفتهم مشرفين مقيمين ينسب الى متغير التهي ات الدراسة ".

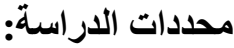
تقتصر الدراسة على الحدود الآتية:

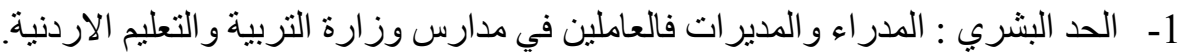

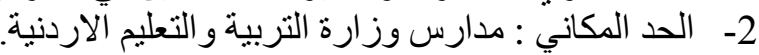
3- الحد الزماني :تم إجر اء الدر اسة خلال الفصل الدر اسلي الاردية الثاني للعام الدراسي 2021

التعريفات الإجرائية: مدير المدرسئة :هو الثخص الثهرية المعين رسميا في وزارة التربية والتعليم، ليكون مسؤو لاً عن سير عمليات المدرسـة المختلفة باتجاه تحقيق أهدافها التربوية.

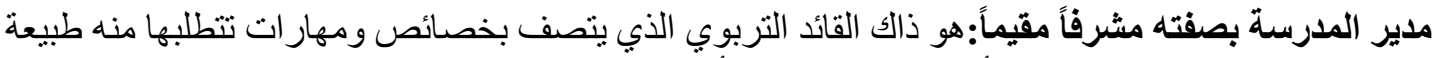

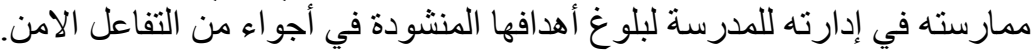

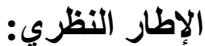

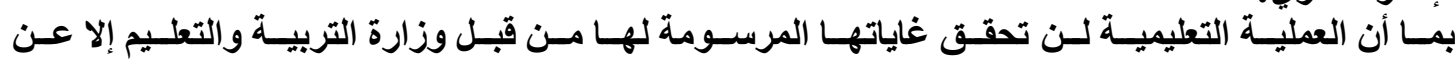

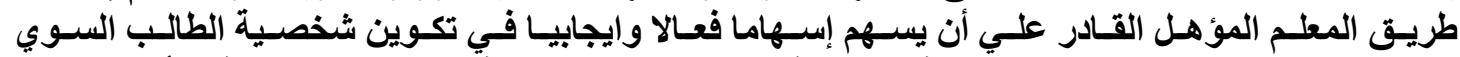

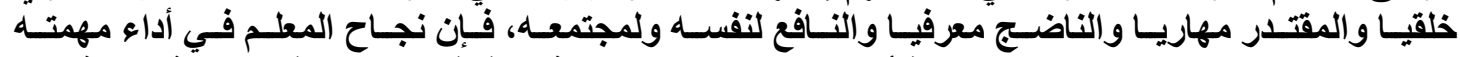

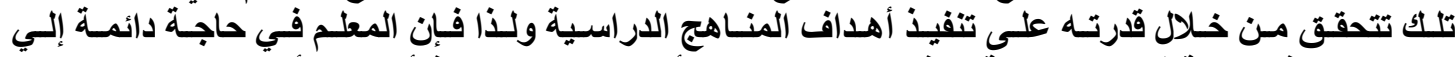

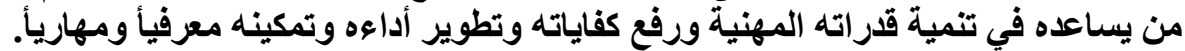

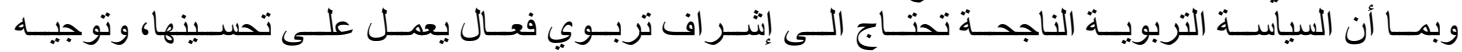

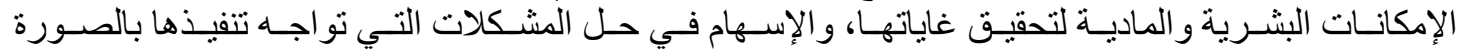

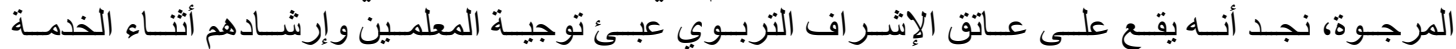

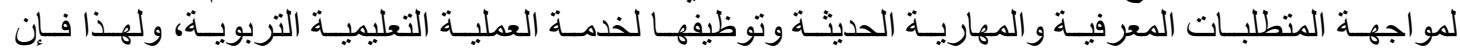

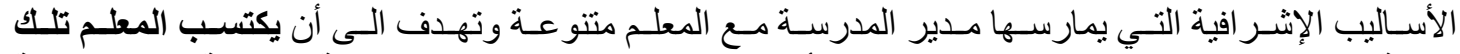

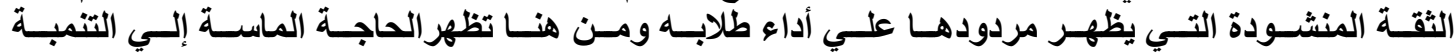

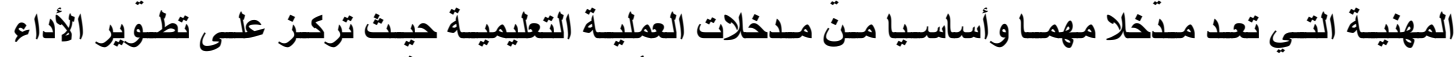

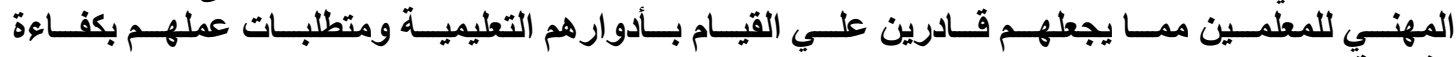

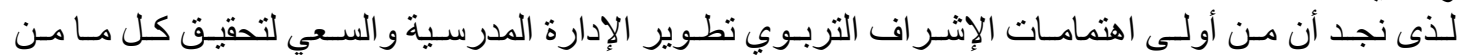

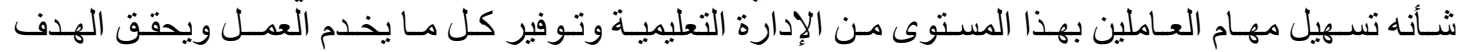

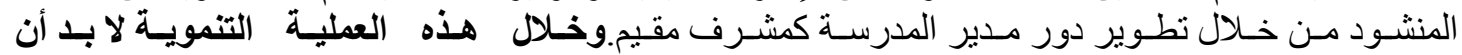

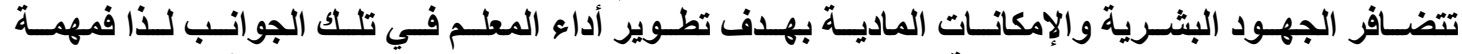

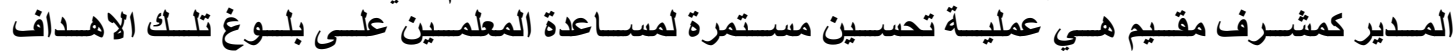

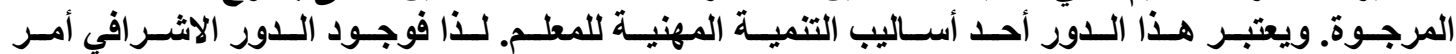




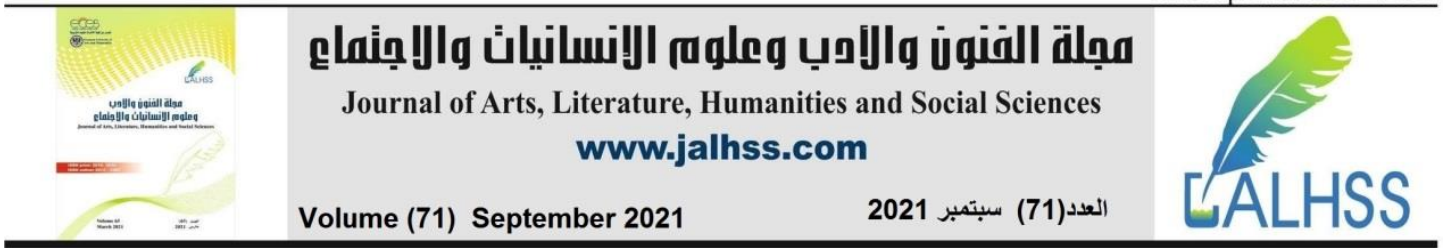

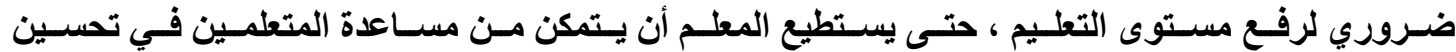

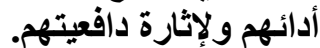

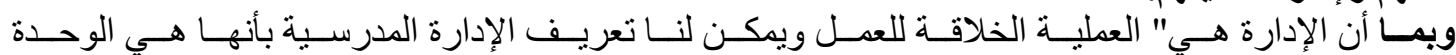

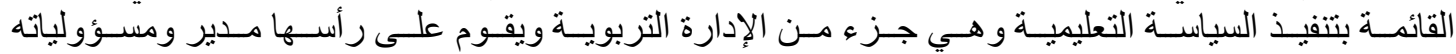

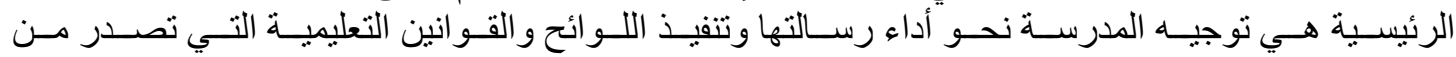

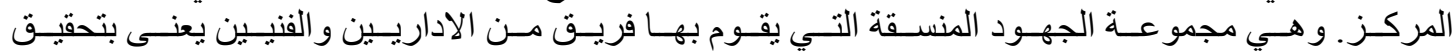

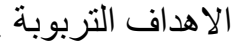

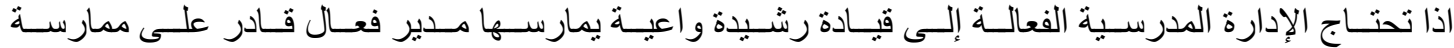
علاقات إنسانية طيية وتهيئة جو مناسب للعمل المدرسي وظروف التهرة اجتماعية مناسبة في بيئة العمل.

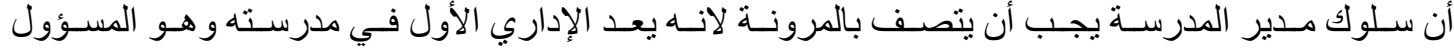

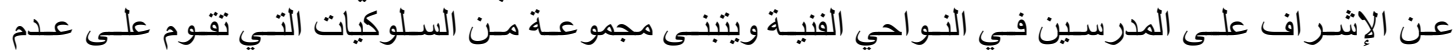

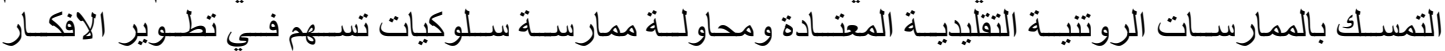

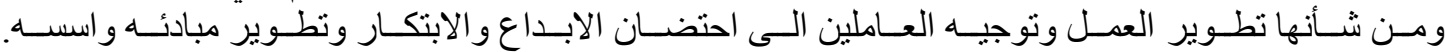

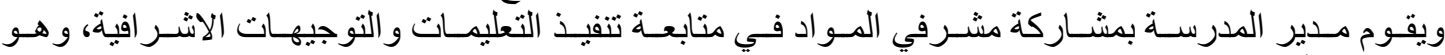

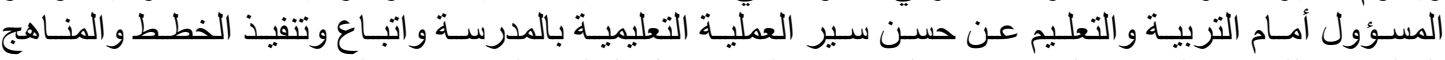
التعليمية و اللوائح و القو انين التي تنتر ها الوز ارة التئ، و المدير يمثل السلطة التنفيذية في المدرسة.

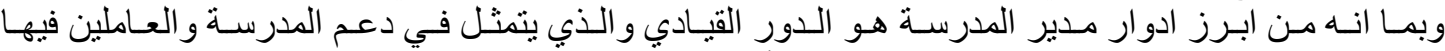

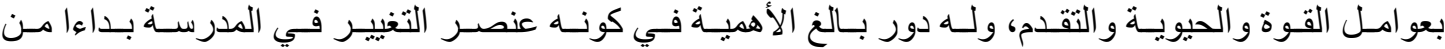

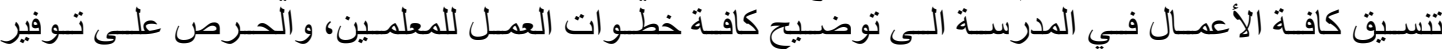

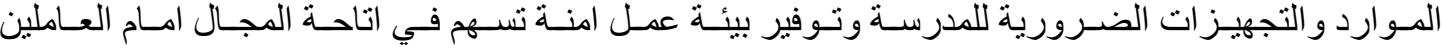

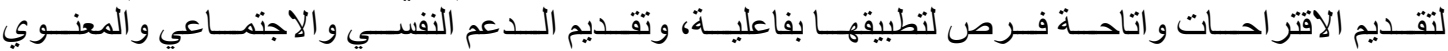

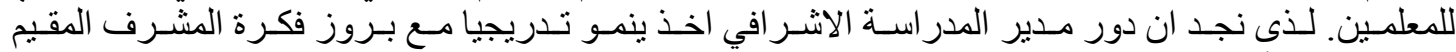

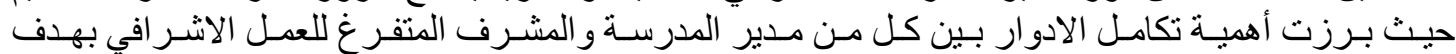
تحقيق غايات و اهداف العملية التعليمية.

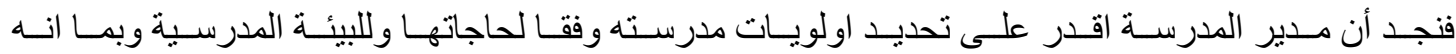

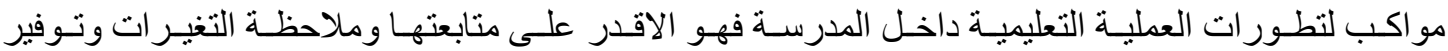
فرص لتلبية الحاجات تللك بشكل افضل.

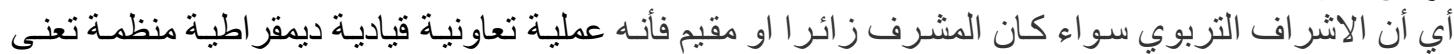

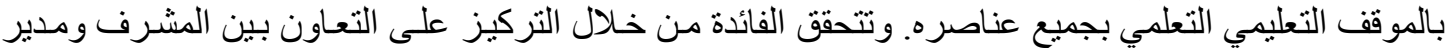

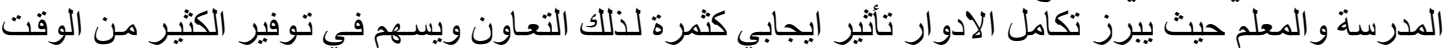

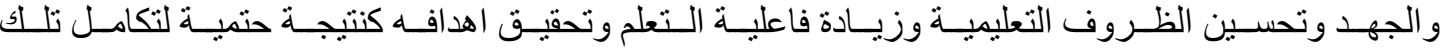

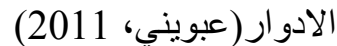

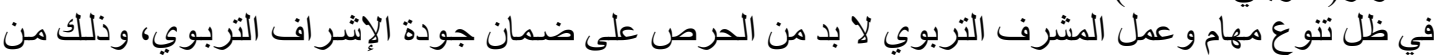

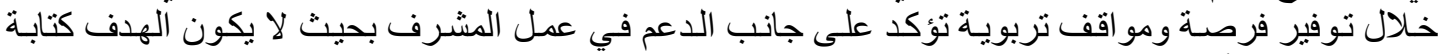

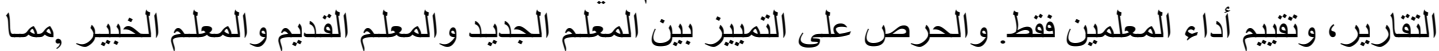

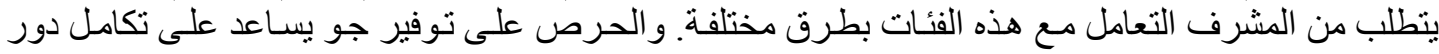
المدير كمشرف مقيم في المدرسة مع دور المشرف التشرف التربوي فنيًا إداريا.(لهلبت ، 2010: 20-24)

مدير المدرسة كمشرف مقيم: مثرير

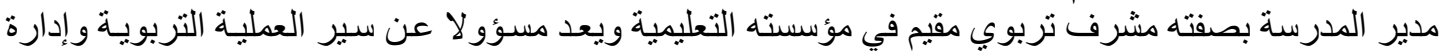

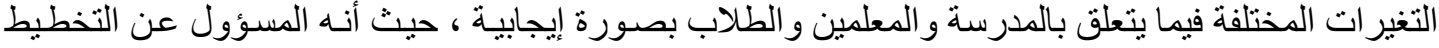

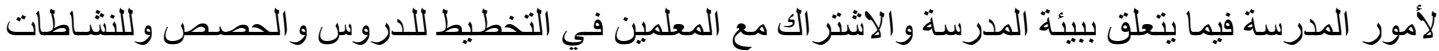

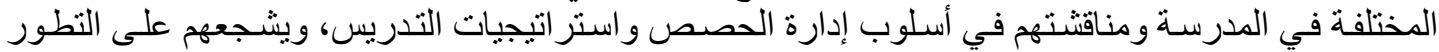
و النمو في مجال عملهم و على التطور في الناحية التكنولوجية وتتجيعهم على الزيـار ات الصفية ، أيضـا هو 


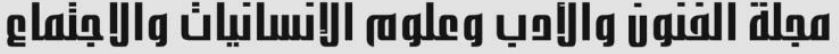

Journal of Arts, Literature, Humanities and Social Sciences www.jalhss.com

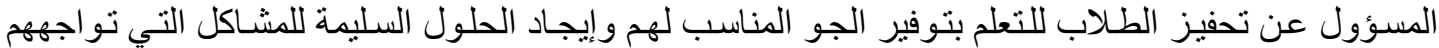

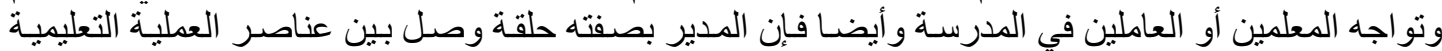
التعلمبة , يكون بذلك المحور الأساس في نجاح المؤسسة التربوية ( القاسم، 2010 )

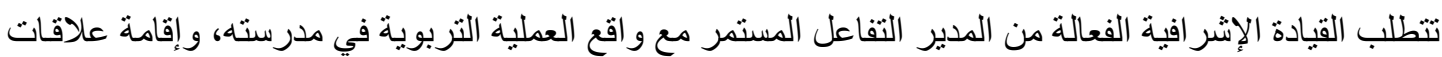

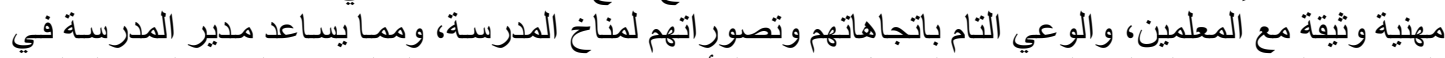

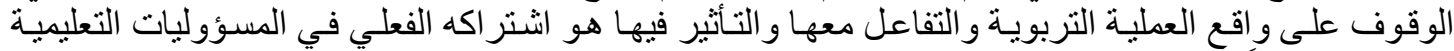

و اعتبار ها جز عاً من مهماته القيادية والإنشر الفية.

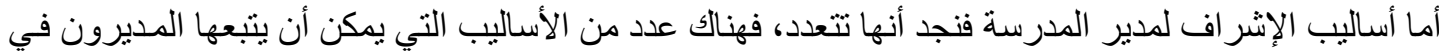

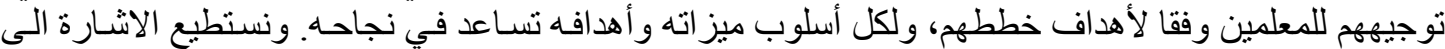

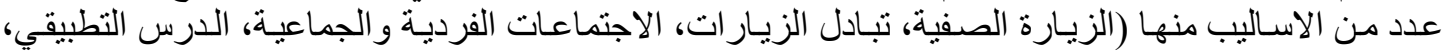

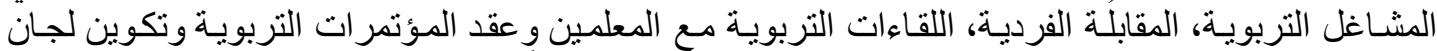

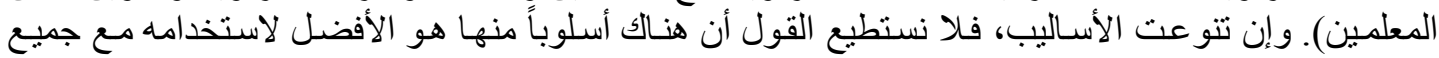

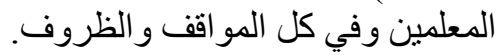

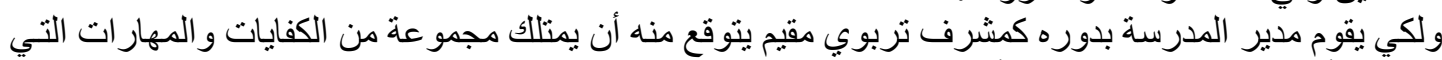

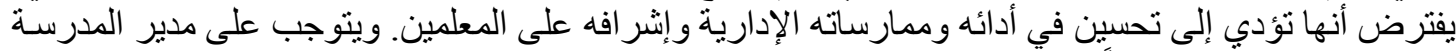

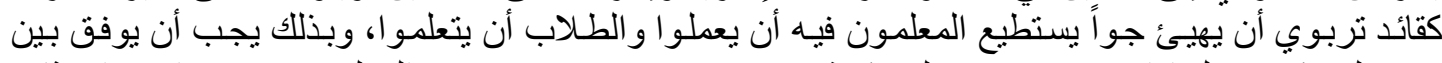

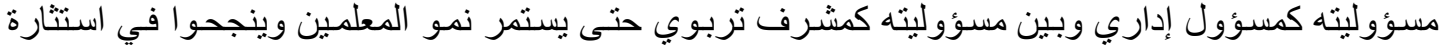

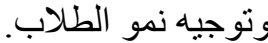

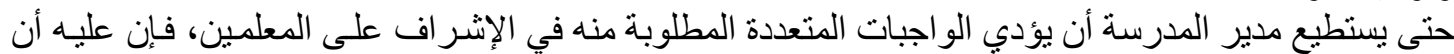

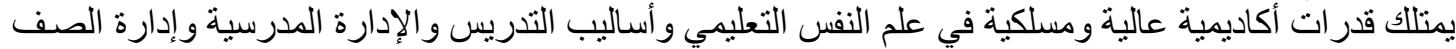

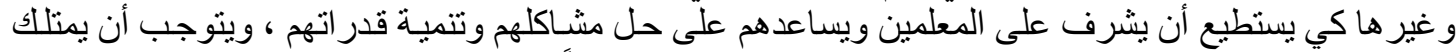

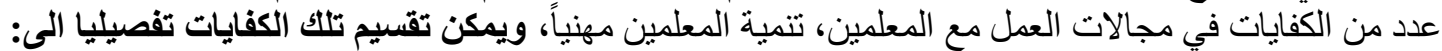

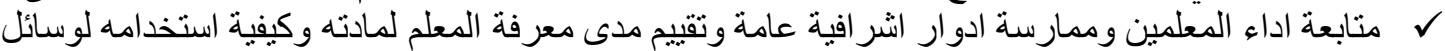

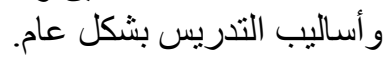
العمل على تتمية قدرته على إدارة الصف ومناقتشته بهدف تمكينه من التخطيط الفعال لدروسه.

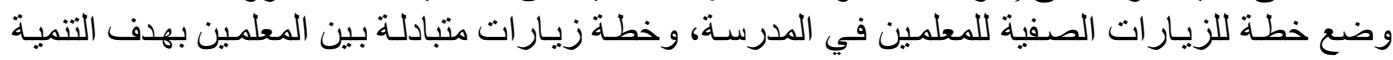

ل توظيف اجتماعات الهيئة التدريسية في المدرسة وتحويلها لوسيلة للتنمية المهنية.

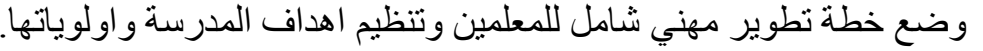

المهارات الاشر افية لمدير المدرسة كمشرف مقيم:

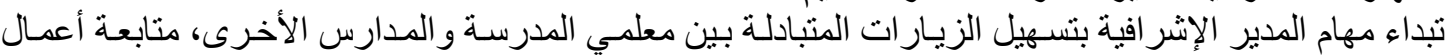

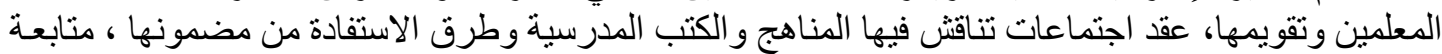

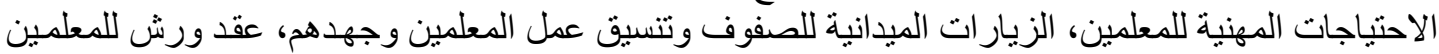

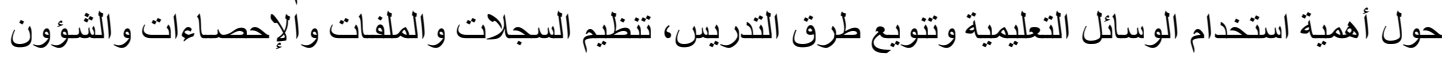

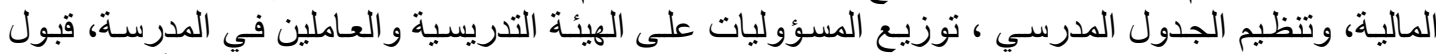

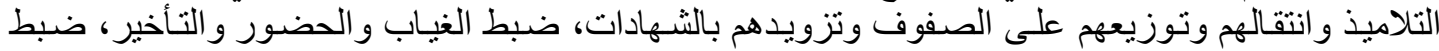

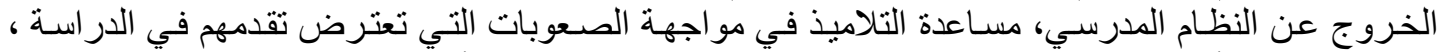

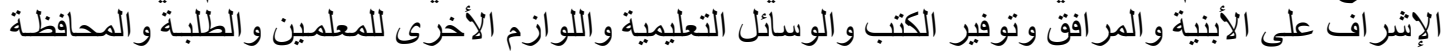

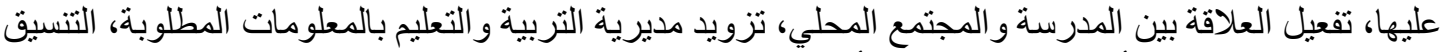

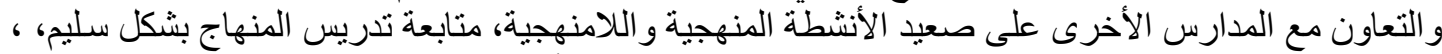

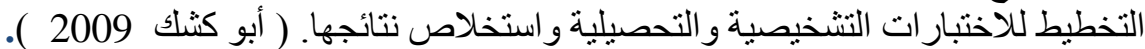
و هنالك العديد من التحديات التي تو اجه المدير في المدارس الحكومية ونسنطيع أن نذكربعض منها كما يلي: 


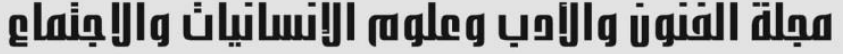

Journal of Arts, Literature, Humanities and Social Sciences www.jalhss.com

1- اختلاف استجابة المعلمين لرؤيـة وتوجيهات المدير فيمـا يتعلق بتطوير أسـاليبهح وطريقتهم في التدريس،

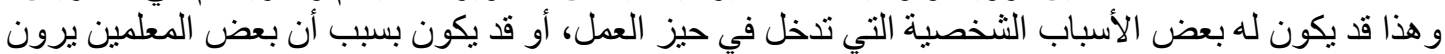

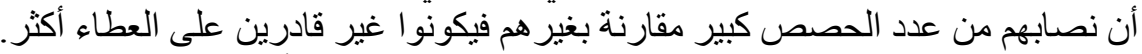

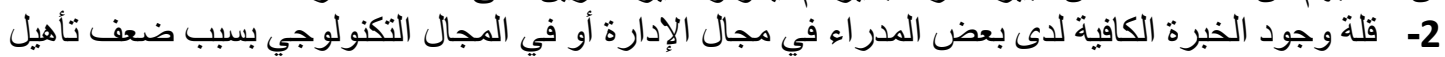

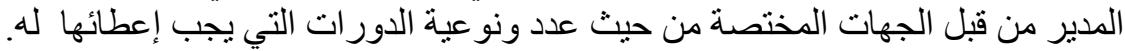

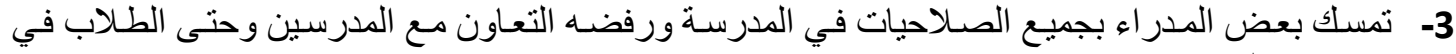
تفويض بعض الصناحيات.

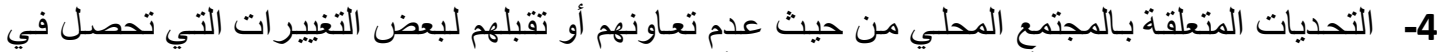
المدرسة حيث يسبب ذللك عائقا أمام المدير في تحقيق الأهداف التي يسعى للوصول إليها.

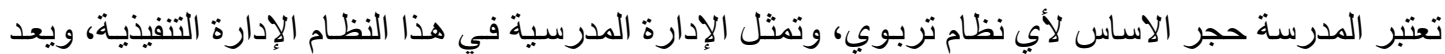

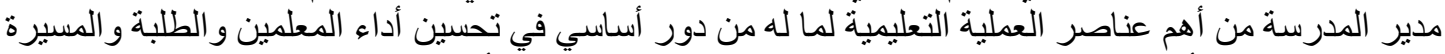

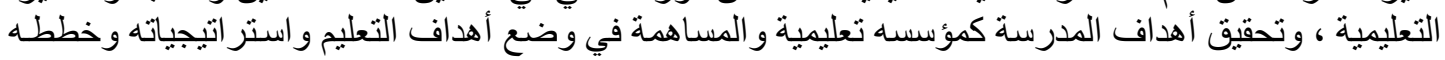

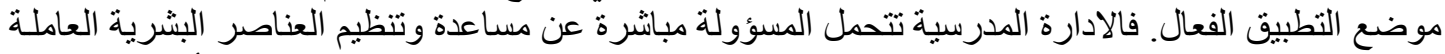

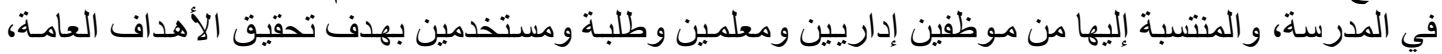

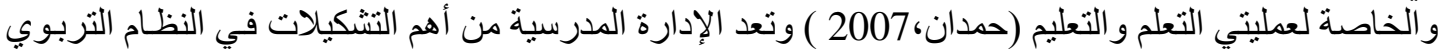

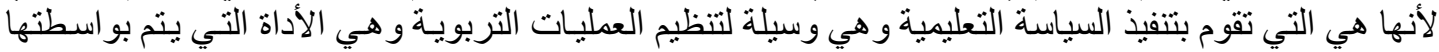

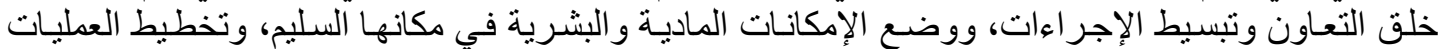

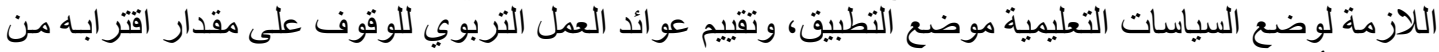
تحقيق الأهداف المرسومة بصورة فعالة.

يمكن أن نعتبر أن مدير المدرسة.

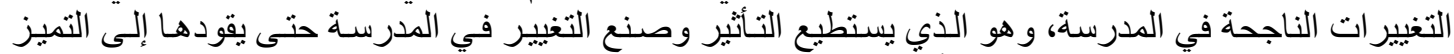

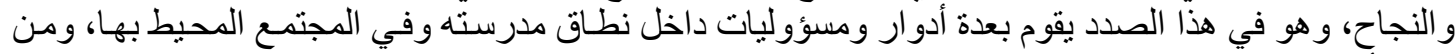

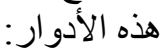

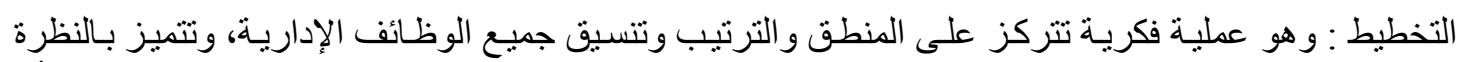

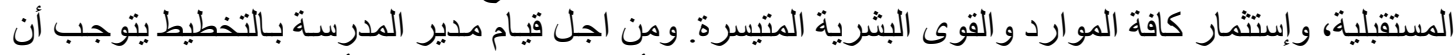

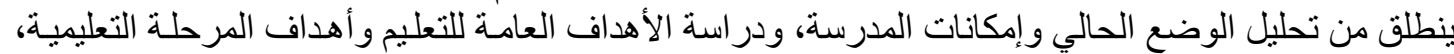
وأن يحرص على إنثر الك العاملين معه في هذه الماني المرحلة.

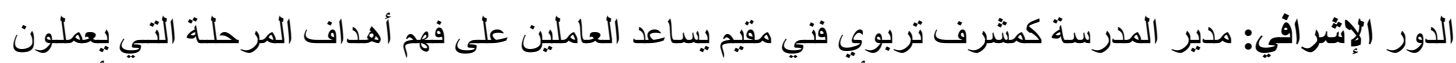

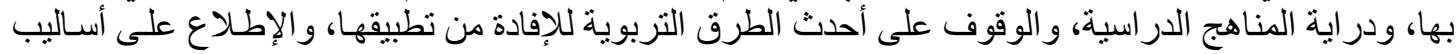

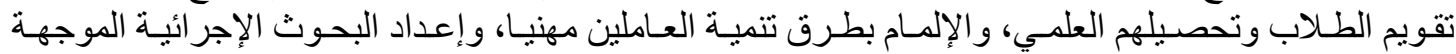

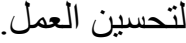

صناعة القرار: يقوم مدير المدرسة بالتعاون مع العاملين وبمشاركتهم بوضع الحلول وبدائلها لحل المشكلات.

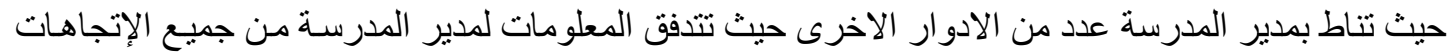

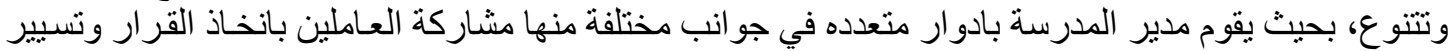

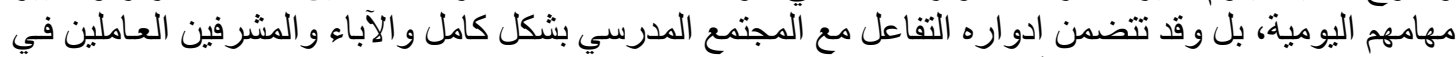

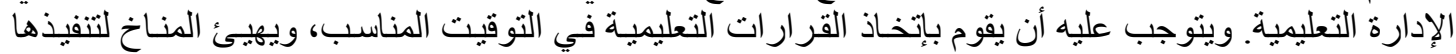

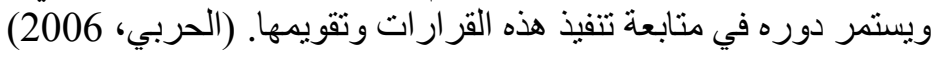

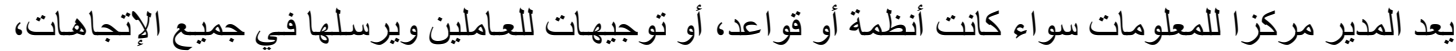
ويعمل على إنشاء شبكة إتصالات يحصل من خلالها على المعلومات للمدرسة و العـاملين فيهاً تساعده في عملية الإنية 


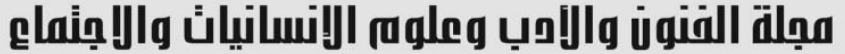

Journal of Arts, Literature, Humanities and Social Sciences www.jalhss.com

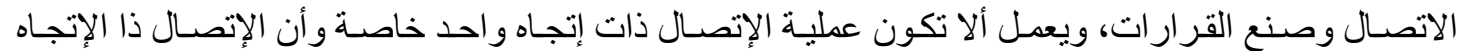

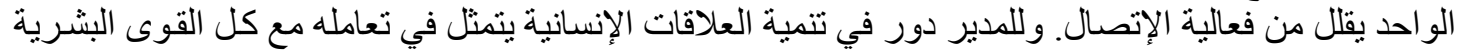

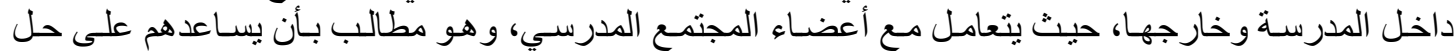

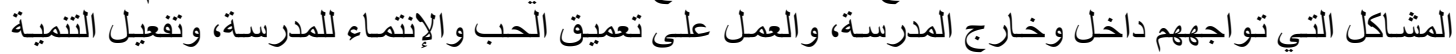

المهنية للعاملين فيها.

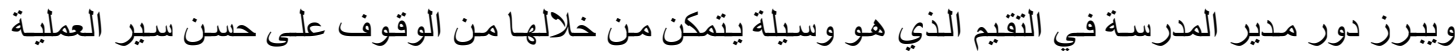

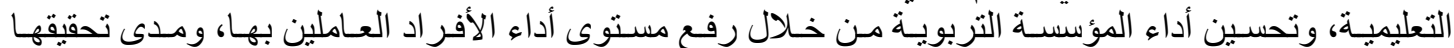

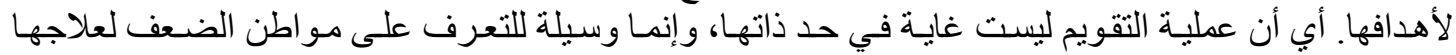

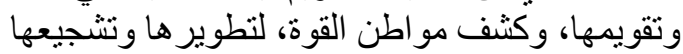

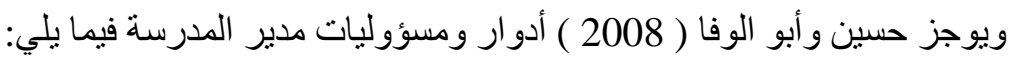
1- التخطيط المدرسي :ويبدأ دوره التخطيطي بدر اسة الأهداف العامـة للتعليم و أهداف المرحلة التعليمية التي التي تنطوي تحتها مدرستها، وكيفية تحقيقها

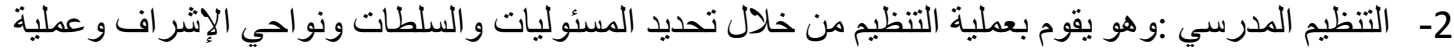

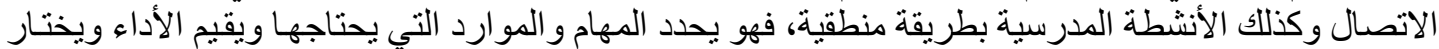

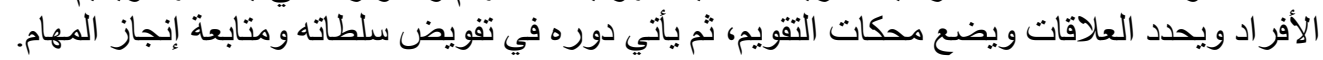

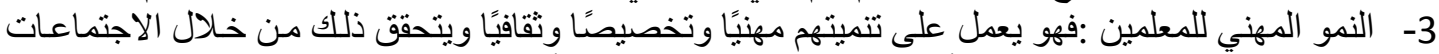

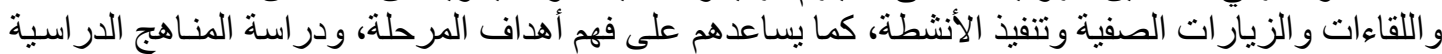

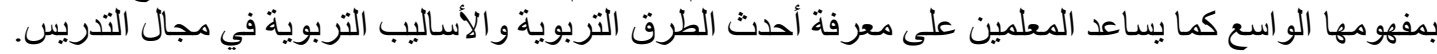

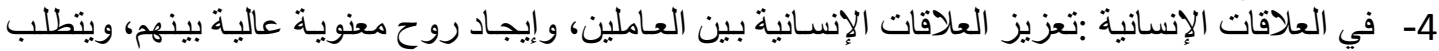

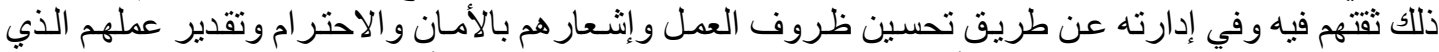

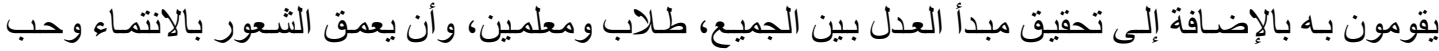
المدرسة و التفاني في خدمة العملية التربوية.

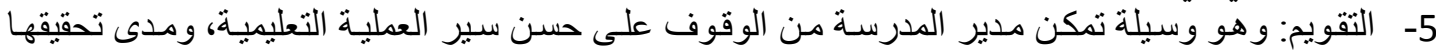

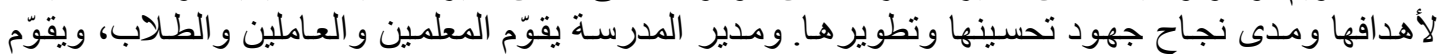

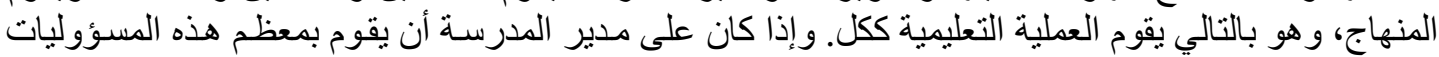

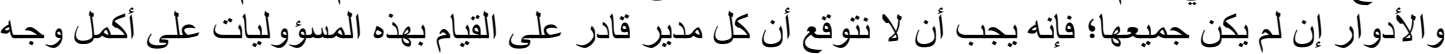

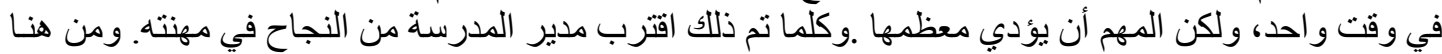

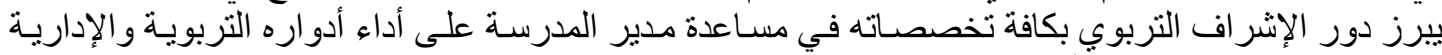

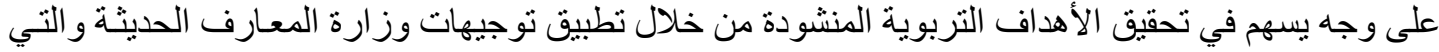

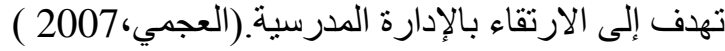

ومن أهم واجبات ومسؤوليات مدير المدرسة ما يلي: ولئي

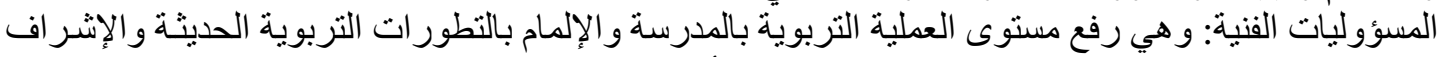

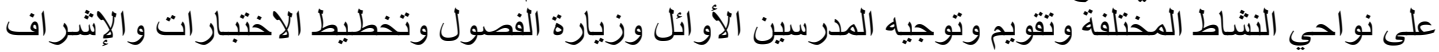

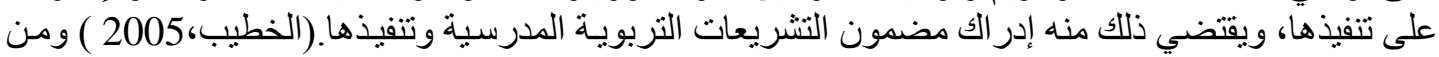

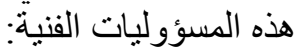

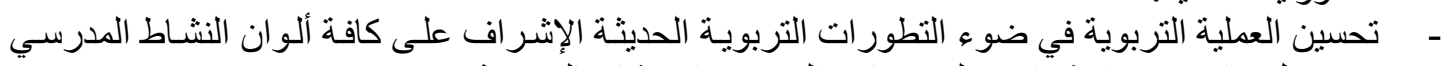

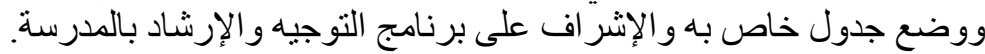

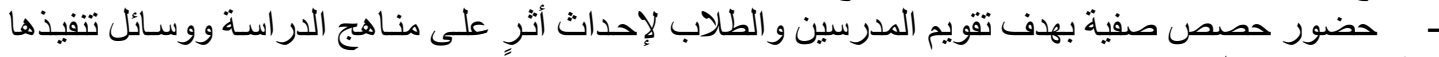
وطرق تدريسها لممارسة دوره الإشر افي. -

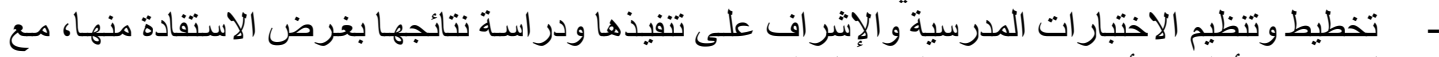

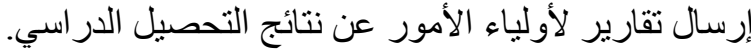




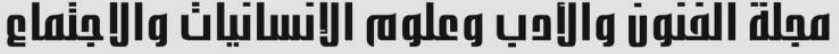

Journal of Arts, Literature, Humanities and Social Sciences www.jalhss.com

- - تقديم التقارير الفنية والإدارية إلى السلطات التعليمية. - حضور الاجتماعات التي تعقدها الإدارة التعليمية.

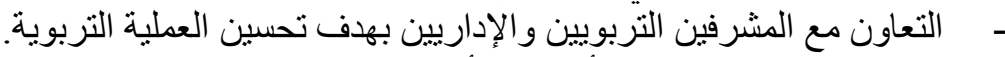

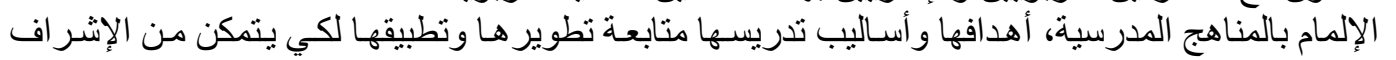

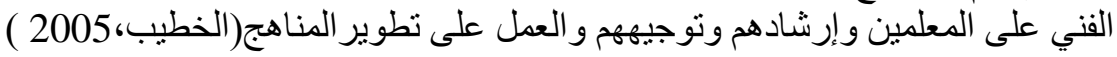

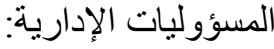
- قبول التلاميذ الجدد و المحولين من مدارس أخرى و إعادة قبدهم في حدود التعليمات المنظمة لذلك.

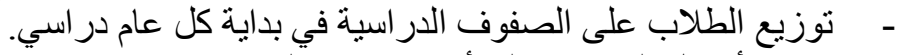
- - - توزيع أعمال المدرسة على أعضاء هيئة التندريس.

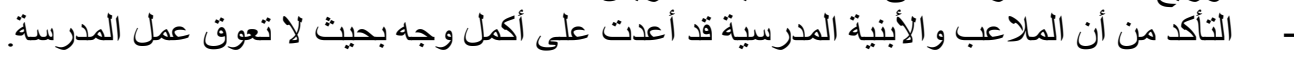
- - ملاحظة غياب الطلاب ودر استه در اسة علمية المابة هادفة. - المحافظة على سلامة المبنى المدرسي ونظافته وردية ونتسيق الخطط لإقامة الأبنية الملحقة و إقامة التعديلات على

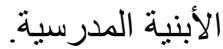
- - - مصر احتياجات المدرسة من قوى بشرية ومادية، ورفعها للإدارة التعليمية قبل بداية العام الدر اسي.

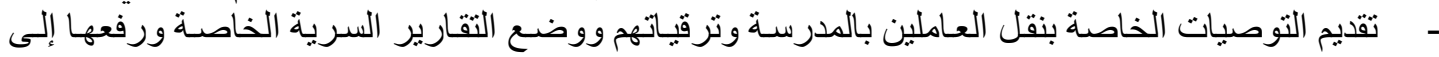
الجهات المختصة. - مر اجعة السجلات والدفاتر المالية والإداريـة من وقت لأخر، نوزيع العمل المدرسي وفق الخطـة الموضو عة(قر عان، حر احشة، التهات

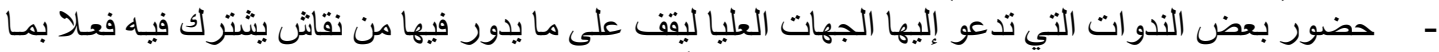

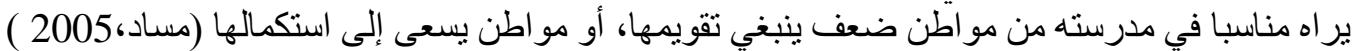
المسؤوليات ذات الصلة بالعلاقات العامة:

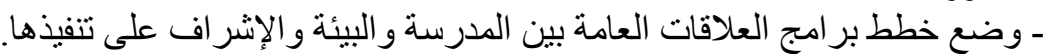

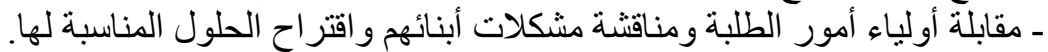

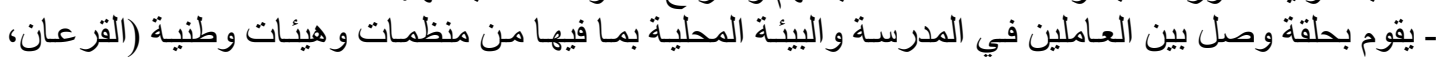
حر احشة. 2005 ( 2005

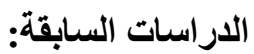

دراسة (نجار،يحيى. علي، عيسى. 2020) بعنوان " دور مدير المدرسة كمشرف تربوي مقيم من وجهة نظر

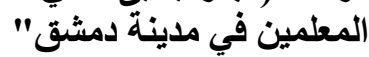

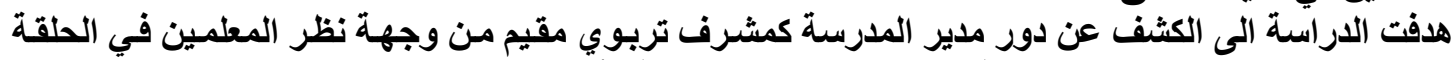

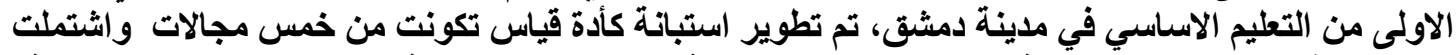

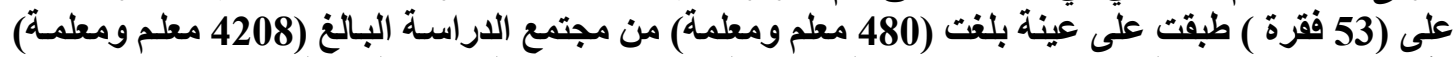

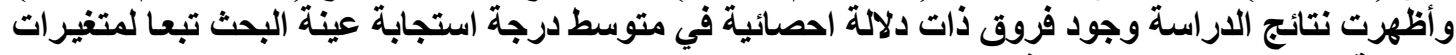

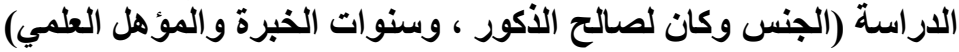

دراسـة (ابو الثـعر،ناهد. 2015) بعنوان" دور مديري المدارس الحكوميـة في ادارة الازمسات بمحافظة غزة

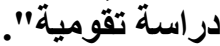

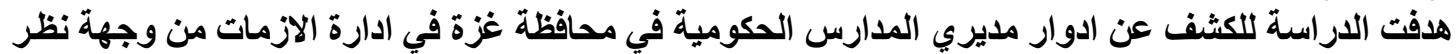

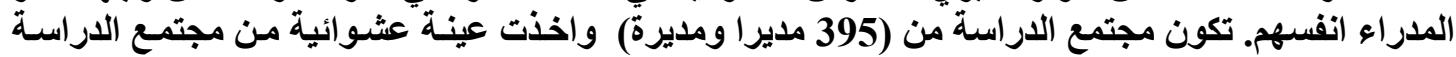




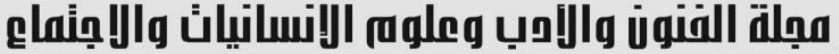

Journal of Arts, Literature, Humanities and Social Sciences www.jalhss.com

Volume (71) September 2021
العدد(71) سبتمبر 2021

بنسبة (\%60) بلغت (242 مديرا ومديرة) واظهرت نتائج الدراسة وجود وزن نسبي كبير لتفعيل ادوار مدير

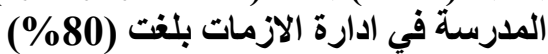

دراسـة (العجمي، 2014) بعنوان " درجـة ممارسـة مديري المدارس الثانويـة في الاردن لدور هم كمشرفين

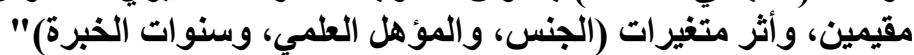

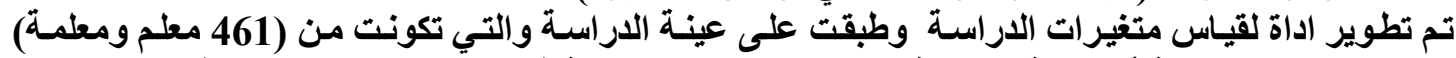

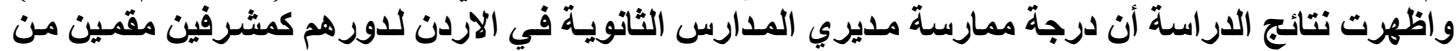

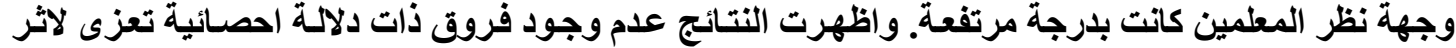

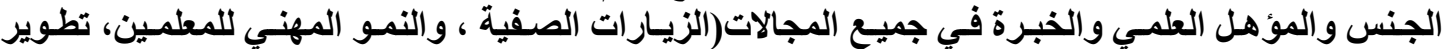

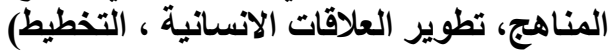

دراسـة(امـا، إجراوي. خليجة،بوخدوة. 2016) دراسـة بعنوان" دور مديري المـارس الابتدائيسة في تحقيق

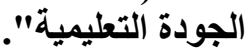

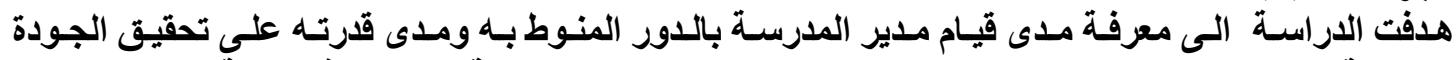

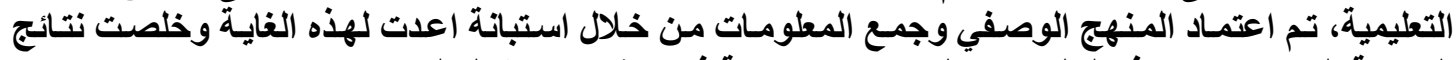

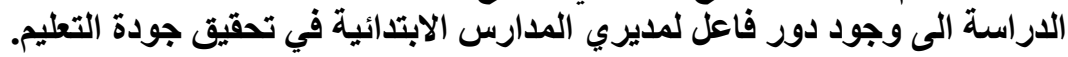

دراسة (الطعاني ، 2012) دراسة بعنوان درجة ممارسة مديري المدارس في الاردن لمهامهم الاشرافية ومدى

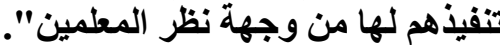

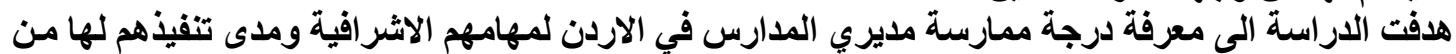

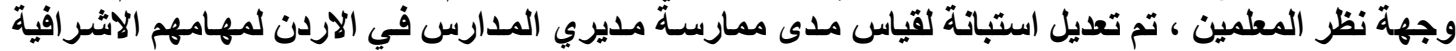

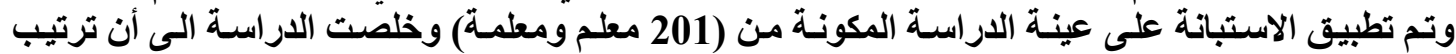

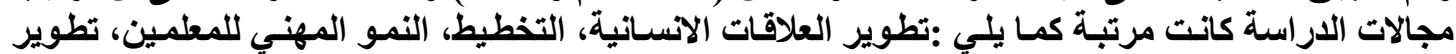

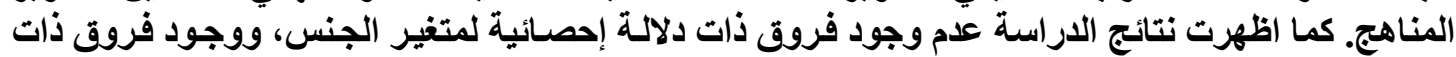

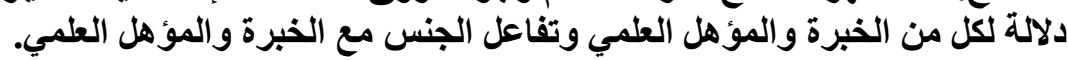

دراسة (محمد العمرات. 2010) بعنوان" درجة فاعلية أداء مديري المدارس في مديريـة البتراء من وجهة

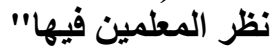

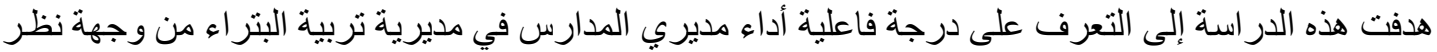

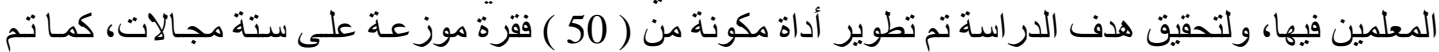

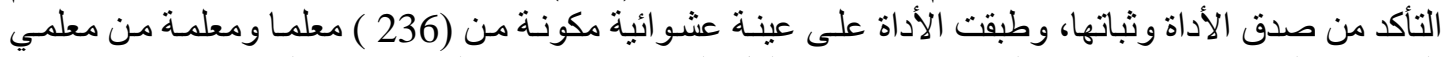

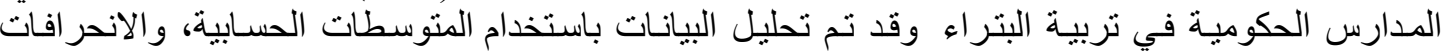

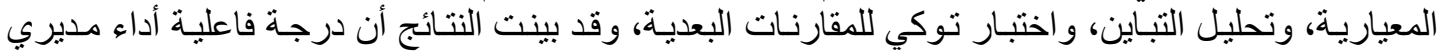

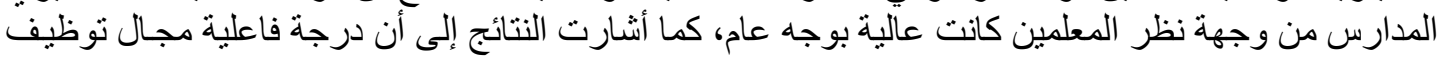

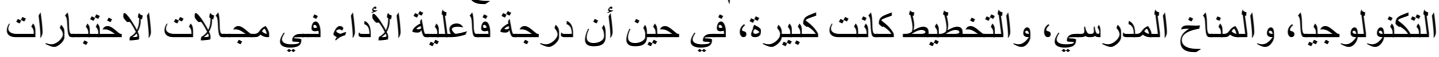

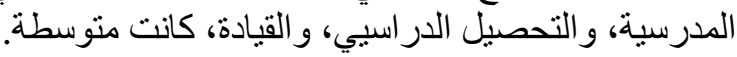

دراسـة (يحيى، محمد. 2018 ) بعنـوان " دور مديري المـدارس الثانويـة في تطوير العلاقـة بين المدرسـة

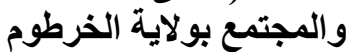

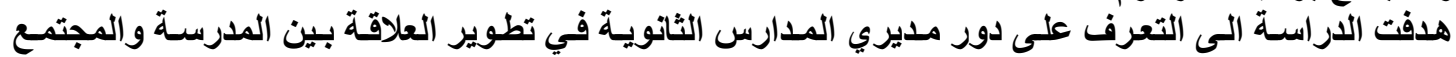

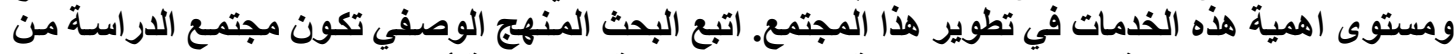

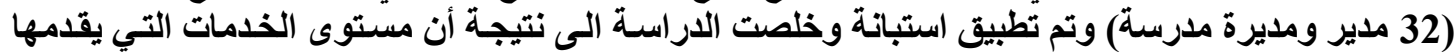

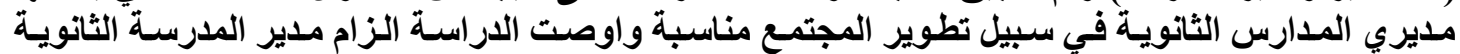

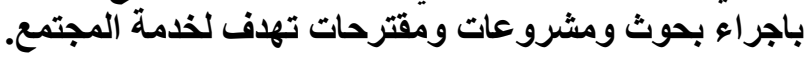




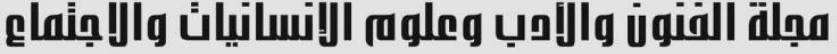

Journal of Arts, Literature, Humanities and Social Sciences www.jalhss.com

دراسة (الغزو، أشـرف. 2019) بعنوان" دور مدير المدرسـة كمشرف تربوي مقيم في المدارس الثانويـة في محافظة عجلون في الاردن"

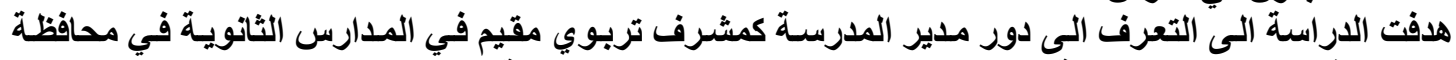

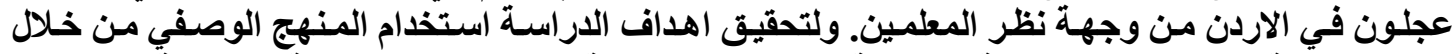

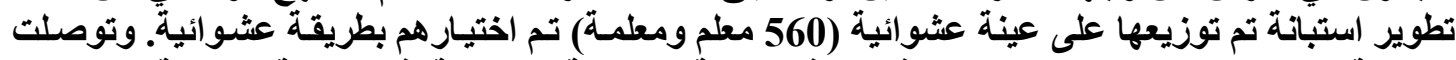

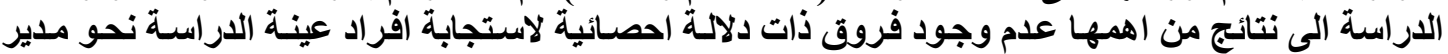

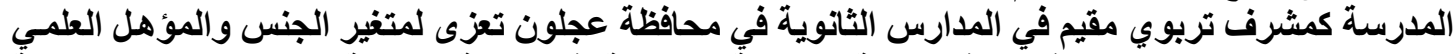

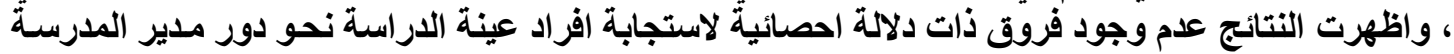

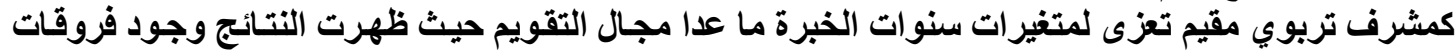

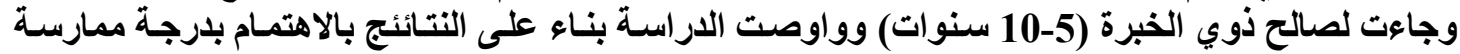

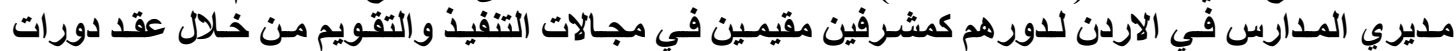

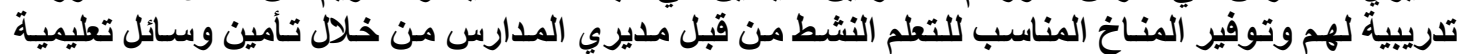

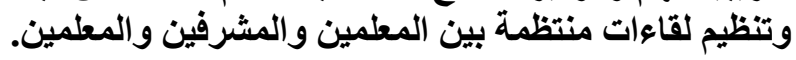

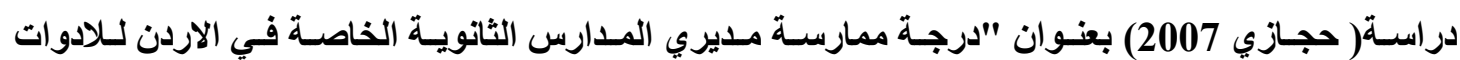

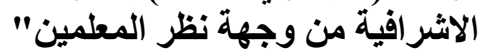

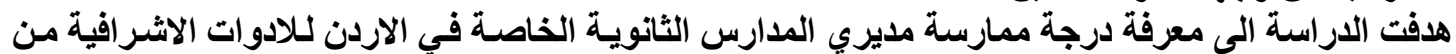

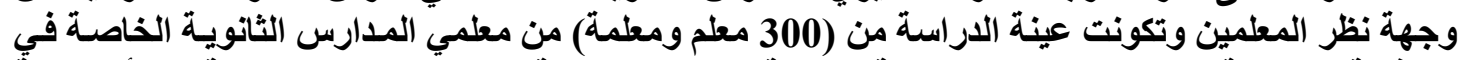

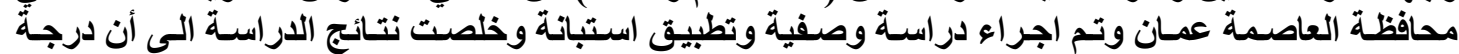

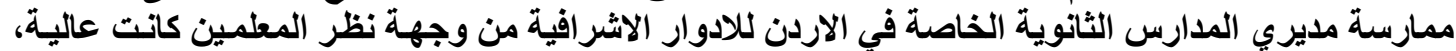

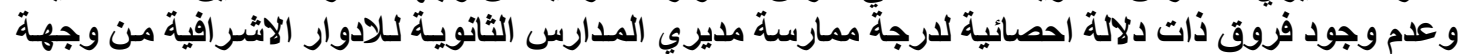

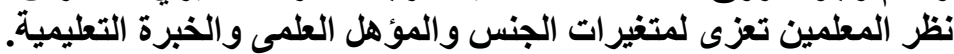

$$
\text { التعليق على الاراسات السابقة : }
$$

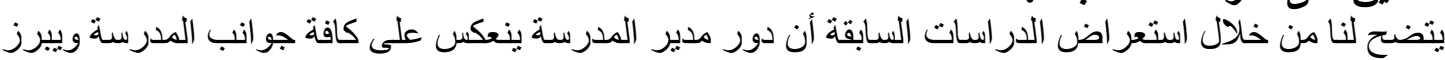

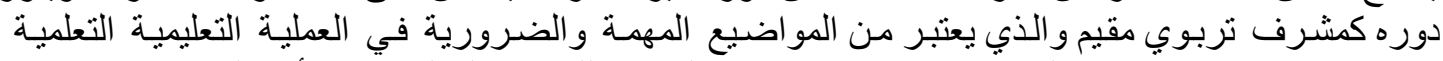

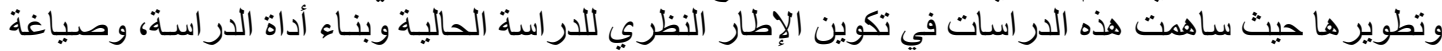

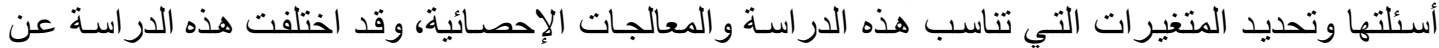

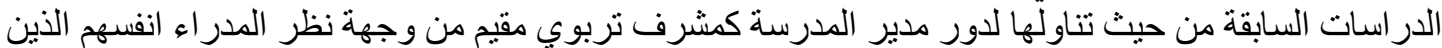

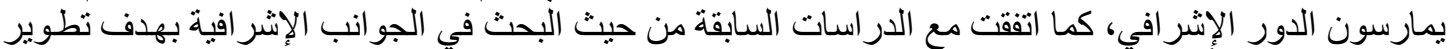
اداء المعلمين مهنياً.

$$
\text { إجراعات البحث الميدانية: }
$$

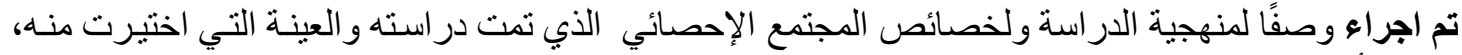

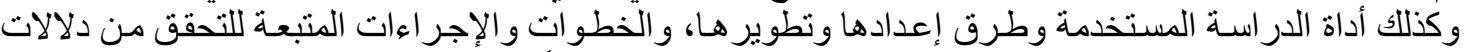

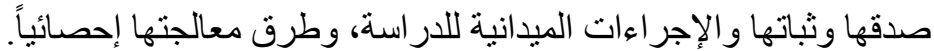

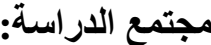

تكون مجتمع الدر اسة من جميع المدر اء و المدير ات العاملين في المدارس الحكومية التابعة لمدارس وزارة التربية 


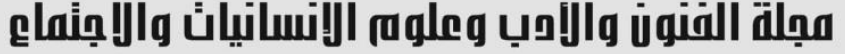

Journal of Arts, Literature, Humanities and Social Sciences www.jalhss.com

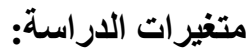

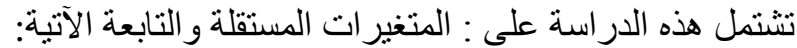

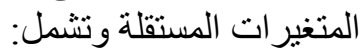

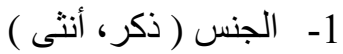

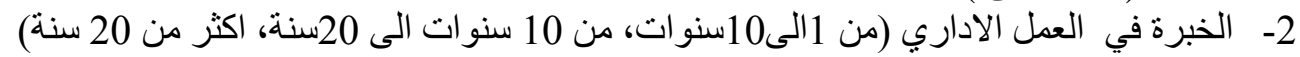

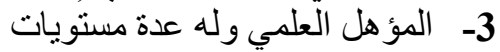

المتغير التابع: ويتمثل في درجة ممارسة مديري المدارس لمهامهم كمشرف مقيم من وجهة نظر هم انفسهم. إجراءات الاراسة: بعد التأكد من صدق وثبات أداة الدر اسـة، وتحديد العينة، قام الباحث بتوزيع الاستبانة على عدد من افر اد مجتمع الدراسة حيث بلغت العينة (30\%)

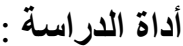

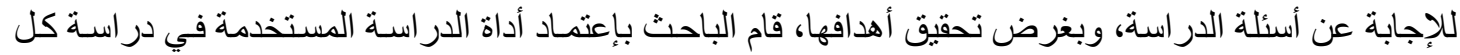

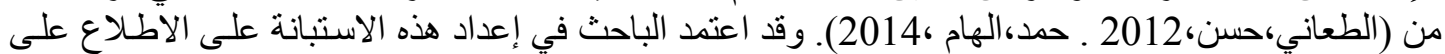

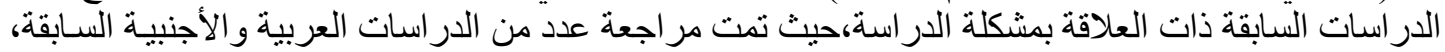

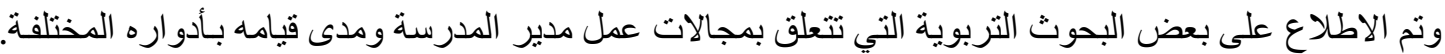

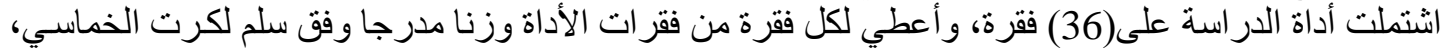

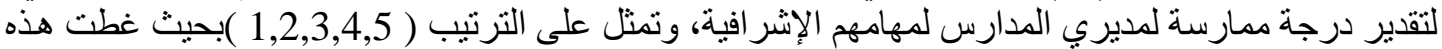

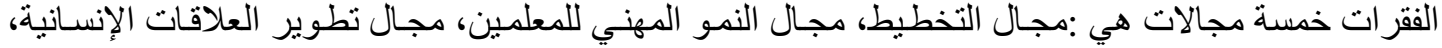

\begin{tabular}{|c|c|c|c|c|c|}
\hline & & & & المناهج، مجآل التقو & جال تطو \\
\hline درجة و اقع قليلة & درجة واقع & درجة واقع & درجة واقع & درجة و اقع كبيرة & الو اقع \\
\hline
\end{tabular}

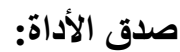

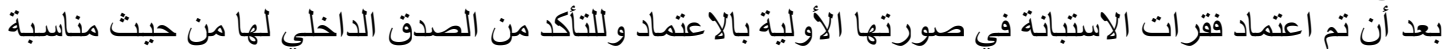

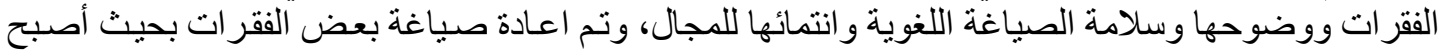
مجموع الفقرات ( 30 ) فقرة.

\section{صدق الإتساق الاخلي لفقرات الاستبانة:}

تم حساب الإتساق الداخلي لفقرات الاستبيان على عينة الدراسة الاستطلاعية حيث تم حساب معاملات الارنباط

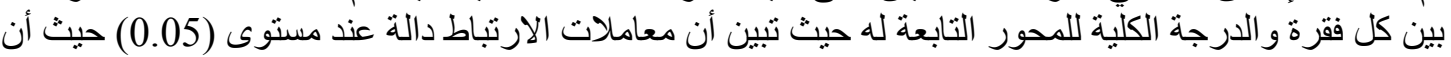
مستوى الدلالة لكل فقرة أقل من (0.05) وقيمة r المحسوبة أكبر من قيمة r الجدولية و التي تساوي (0.39)

$$
\text { صدق الاتساق البنائي لمحاور الدراسة:- }
$$

جدول رقم (3) يبين معاملات الارتباط بين معدل كل محور من محاور الدراسة مع المعدل الكلي لفقرات

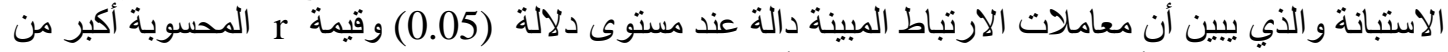
قيمة r الجدولية حيث أن مستوى الدلالة لكل فقرة أقل من (0.05 ) قيمة r الجدولية تساوي (3.96) 


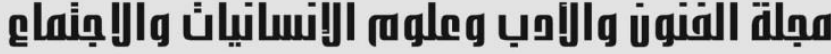

Journal of Arts, Literature, Humanities and Social Sciences www.jalhss.com

| (71) (71) سبتمبر 2021

جدول رقم (1)- صدق الاتساق البنائي

\begin{tabular}{|c|c|c|c|}
\hline مستوى الدلالة & معامل الارتباط & المجالات & رقالمور \\
\hline 0.00 & 0.930 & مجال التخطيط & الاول \\
\hline 0.00 & 0.823 & مجال النمو المهني للمعلمين & الثاني \\
\hline 0.00 & 0.833 & مجال تطوير العلاقات الإنسانية & 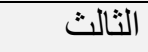 \\
\hline 0.00 & 0.823 & مجال نطوير المناهج. & 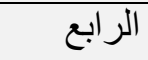 \\
\hline 0.00 & 0.926 & التقويم & الخامس \\
\hline
\end{tabular}

Reliability 3-4-3 ثبات فقرات الاستبانة

أما ثبات أداة الدراسة فيعني التأكد من أن الإجابة ستككون قريبة لو تكرر تطبيقها على الأشخاص ذاتهم في في أوقات مختلفة وقد أجرى الباحث خطو ات الثي الثبات على العينة الاسنطلاعية نفسها بطريقة التجزئة النصفية.

Split-Half Coefficient 1-3-4-3 طريقة التجزئة النصفية:

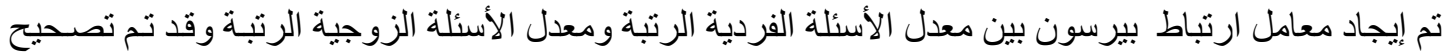
معاملات الارتباط باستخدام معامل ارتباط سبيرمان براون للتصحيح (Spearman-Brown Coefficient) حسب المعادلة التالية :

$$
\text { معامل الثبات = R+1/ R2 حيث R معامل الارتباط }
$$

وقد تبين أن هناك معامل ثبات كبير نسبياً لفقرات الاستبيان كما يوضح جدول رقم (2)

\begin{tabular}{|c|c|c|c|c|c|}
\hline \multicolumn{4}{|c|}{ التجزئة النصفية } & \multirow[b]{2}{*}{ عنوان المجال } & \multirow[b]{2}{*}{ المجال } \\
\hline المعنوية مستوى & معامل الارتباط & معامل الارتباط & الفقرات & & \\
\hline 0.000 & 0.8860 & 0.7954 & 6 & مجال التخطيط & -1 \\
\hline 0.000 & 0.9049 & 0.8262 & 6 & مجال النمو المهني للمعلمين & -2 \\
\hline 0.000 & 0.8635 & 0.7597 & 6 & مجال تطوير العلاقات الإنسانية & -3 \\
\hline 0.000 & 0.8402 & 0.7224 & 7 & مجال تطوير المناهج. & -4 \\
\hline 0.000 & 0.8861 & 0.7954 & 15 & التقويم & -5 \\
\hline
\end{tabular}




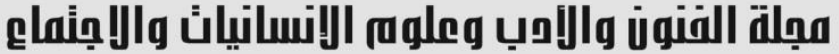

Journal of Arts, Literature, Humanities and Social Sciences www.jalhss.com

\begin{tabular}{|l|l|l|r|r|l|}
\hline 0.000 & & 55 & المجموع & \\
\hline
\end{tabular}

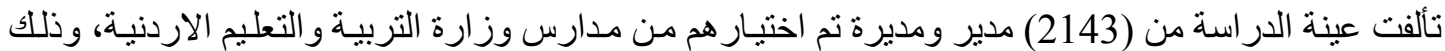

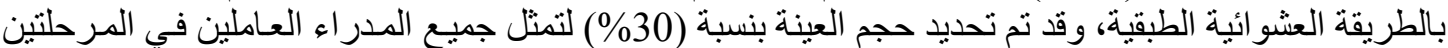
(المدارس الأساسية و المدارس الثنانوية ) ، و الجدول رقم(3)يوضح نوزيع عينة الدر اسـة حسب الجنس و الخبرة

جدول رقم (3 ) توزيع عينة الاراسة حسب متغيرات الدراسة المستقلة

\begin{tabular}{|c|c|c|c|c|c|c|}
\hline $\begin{array}{c}\text { الفرق } \\
\text { variance }\end{array}$ & الإنحرياف & الحسابي & المئوية & التكر ار ات & & \\
\hline \multirow[t]{2}{*}{0,37} & \multirow[t]{2}{*}{0,606} & \multirow[t]{2}{*}{2,089} & $\% 77$ & 1650 & +بكالوريوس تربوي & \multirow[t]{2}{*}{ المؤهل } \\
\hline & & & $\% 23$ & 493 & در اسات عليا & \\
\hline \multirow[t]{2}{*}{0,24} & \multirow[t]{2}{*}{0,49} & \multirow[t]{2}{*}{1,61} & $\% 37$ & 791 & ذكر & \multirow[t]{2}{*}{ الجنس } \\
\hline & & & $\% 63$ & 1350 & انثى & \\
\hline \multirow[t]{4}{*}{0.68} & \multirow[t]{3}{*}{0,83} & \multirow[t]{3}{*}{1.73} & $\% 51$ & 1072 & اقل من 10سنو ات & \multirow{3}{*}{ في الخبرة } \\
\hline & & & $\% 20.4$ & 437 & من 10 الى 20 & \\
\hline & & & $\% 29.6$ & 634 & اكثر من 20 سنة & \\
\hline & & & $\% 100$ & 2143 & & المجموع \\
\hline
\end{tabular}

يبيين الجدول رقم (1) أن ما نسبته 77\% من عينة الدر اسـة مؤهلهم العلمي" بكالوريوس بالاضـافة لدبلوم ادارة

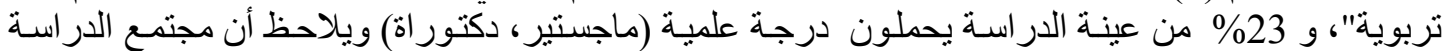

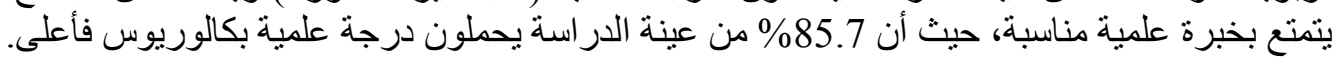
و يبين الجدول رقم (1) أن ما نسبته 51\%من عينة الدراسة تراوحت خبر اتهم من 1-10 سنو ات، 20,4 20,4\% من

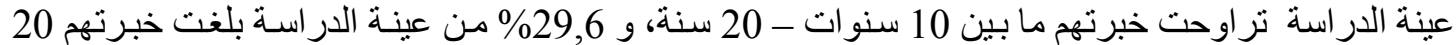

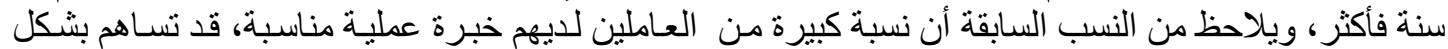

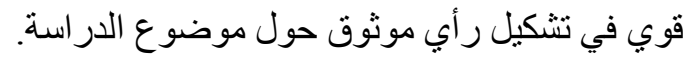
يبين جدول رقم (3) أن 37 \% من عينة الدراسة من الذكور، 63\% من عينة الدر اسة من الإناث. 


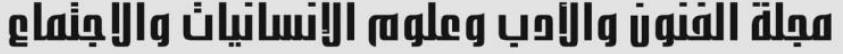

Journal of Arts, Literature, Humanities and Social Sciences www.jalhss.com

ولتحليل البيانات التي تم جمعها، فقد تم استخدام العديد من الأسـاليب الإحصـائية المناسبة باستخدام الحزم الإحصائية للعلوم الإجتماعية Social Science Statistical Package for) SPSS وفيما يلي مجمو عة من الأساليب الإحصائية المستخدمة في تحليل البيانات: 1- ترميز و إدخال البيانات الإحصائية حسب مقياس تدريجي مقسم الى( 5) نقاط حيث أن القيمـة (1) تعني أقل مو افقة على محتوى الفقرة، والقيمة (5) تعني أعلى مو افقة على الفقرة. 2-تم حساب التكرارات و النسب المئوية للتعرف على الصفات الثخصية لـفردات الدر اسـة وتحديد استجابات

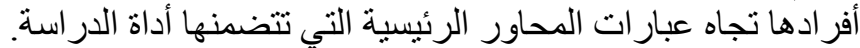

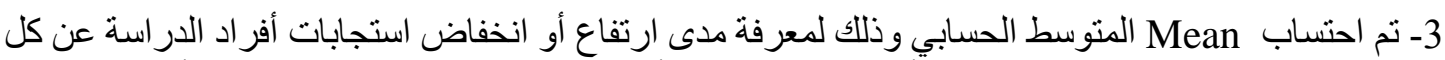

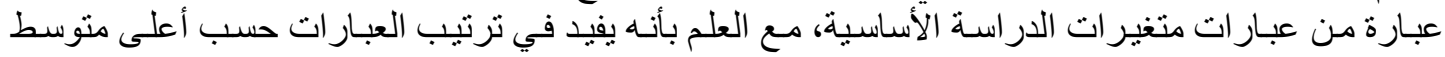
حسابي. 4- اختبار معامل ارتباط بيرسون لقياس صدق الفقرات 5- 5عادلة سبيرمان بر اون للثبات

6- اختبار كولومجروفـ سمرنوف لمعرفة نوع البيانات هل تتبع التوزيع الطبيعي أم لا(1-Sample K-S ) 6- لمعرفة الفرق بين متوسط عينة واحدة او عينتان تم استخدام ( t-test)

عرض النتائج: يتضمن هذا الفصل عرضا للنتائج التي توصلت إليها الدر اسة حيث تم تصنيفها وفقا لأسئلة الدر اسـة على النحو

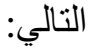
السؤال الأول: ما مدى تطبيق مدراء المدارس لمهامهم الإثرافية من وجهة نظر مدراء المدارس الحكومية

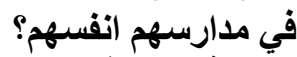
للإجابة عن هذار السؤال تم استخراج المتوسطات الحسابية والوزن النسبي لإجابات أفر اد عينة الدراسة عن كل

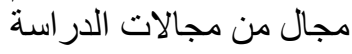
ونظر اً لوجود خمسة مجالات كمحاور اساسية في الدراسة تساعد في الإجابة على اسئلتها لذا تناول الباحث هذه

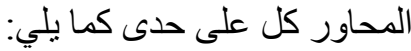




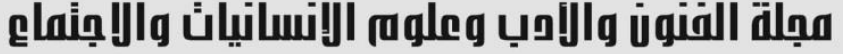

Journal of Arts, Literature, Humanities and Social Sciences

www.jalhss.com

Volume (71) September 2021

\section{¿ALHSS}

جدول رقم(4) مجال التخطيط

جدول رقم (4) المتوسطات الحسابية والوزن النسبي لاستجابات المدراء على مجال التخطيط

\begin{tabular}{|c|c|c|c|c|c|c|c|c|c|c|c|c|c|c|c|}
\hline \multirow{3}{*}{ 第 } & \multirow{3}{*}{ 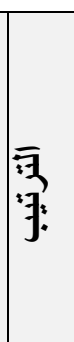 } & \multirow{3}{*}{ 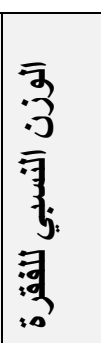 } & \multirow{3}{*}{ 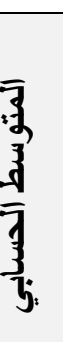 } & \multicolumn{10}{|c|}{ التكرارات والنسب المئوية لأستجابات العينة } & \multirow[b]{3}{*}{ 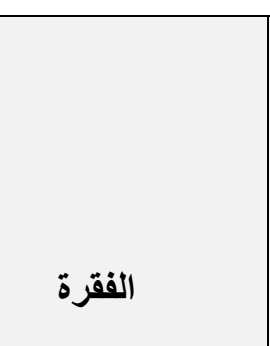 } & \multirow{3}{*}{ 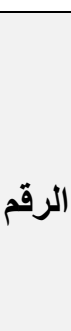 } \\
\hline & & & & \multicolumn{2}{|c|}{ منخفاً } & \multicolumn{2}{|c|}{ منخفضة } & \multicolumn{2}{|c|}{ متوسطة } & \multicolumn{2}{|c|}{ عالية } & \multicolumn{2}{|c|}{ عالية جداً } & & \\
\hline & & & & $\%$ & $ت$ & $\%$ & $ت$ & $\%$ & 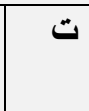 & \% & $ت$ & $\%$ & ت & & \\
\hline منة سد & 1 & $\% 62$ & 3,1 & $\% 6,4$ & $\begin{array}{r}13 \\
6\end{array}$ & $\begin{array}{r}21,8 \\
\%\end{array}$ & $\begin{array}{r}46 \\
6\end{array}$ & $\begin{array}{c}\% \\
49,5\end{array}$ & $\begin{array}{r}105 \\
6\end{array}$ & $\begin{array}{c}21,7 \\
\%\end{array}$ & $\begin{array}{r}46 \\
4\end{array}$ & $\begin{array}{r}0,6 \\
\%\end{array}$ & 12 & 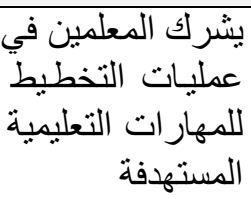 & 1 \\
\hline قليلة & 2 & $\begin{array}{r}\% \\
59.2\end{array}$ & $\begin{array}{r}2,9 \\
6\end{array}$ & $\% 9,7$ & $\begin{array}{r}20 \\
8\end{array}$ & $\% 21$ & $\begin{array}{r}44 \\
9\end{array}$ & $\begin{array}{l}\% \\
31,3\end{array}$ & 667 & $\begin{array}{r}31,7 \\
\%\end{array}$ & $\begin{array}{r}67 \\
6\end{array}$ & $\begin{array}{r}6,3 \\
\%\end{array}$ & $\begin{array}{r}13 \\
4\end{array}$ & 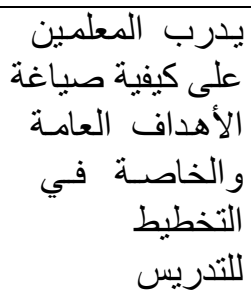 & -2 \\
\hline قليلة & 3 & $\% 58$ & 2,9 & $\% 0,7$ & 16 & $\% 21$ & $\begin{array}{r}44 \\
9\end{array}$ & $\begin{array}{l}\% \\
\mathbf{5 0 , 4}\end{array}$ & $\begin{array}{r}107 \\
6\end{array}$ & $\begin{array}{r}26,3 \\
\%\end{array}$ & $\begin{array}{r}56 \\
1\end{array}$ & $\begin{array}{r}1,5 \\
\%\end{array}$ & 32 & 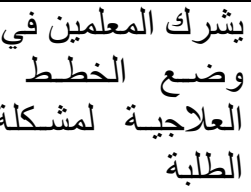 & 3 \\
\hline قليلة & 4 & $\begin{array}{r}57.8 \\
\%\end{array}$ & $\begin{array}{r}2,8 \\
9\end{array}$ & $\% 7,7$ & $\begin{array}{r}16 \\
5\end{array}$ & $\% 18$ & $\begin{array}{r}38 \\
5\end{array}$ & $\begin{array}{l}30,5 \\
\%\end{array}$ & 650 & $\begin{array}{r}43,2 \\
\%\end{array}$ & $\begin{array}{r}92 \\
1\end{array}$ & $\begin{array}{r}0,6 \\
\%\end{array}$ & 13 & 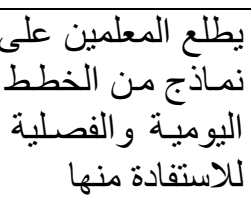 & -4 \\
\hline قليلة & 5 & $\begin{array}{r}57.2 \\
\%\end{array}$ & $\begin{array}{r}2,8 \\
6\end{array}$ & $\% 0,7$ & 16 & $\begin{array}{r}\% \\
12,9\end{array}$ & $\begin{array}{r}27 \\
6\end{array}$ & $\begin{array}{l}\% \\
\mathbf{5 9}, 6\end{array}$ & $\begin{array}{r}127 \\
1\end{array}$ & $\begin{array}{r}25,4 \\
\%\end{array}$ & $\begin{array}{r}54 \\
1\end{array}$ & $\begin{array}{r}1,4 \\
\%\end{array}$ & 30 & 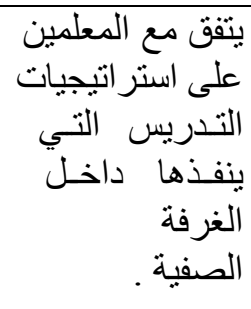 & 5 \\
\hline
\end{tabular}




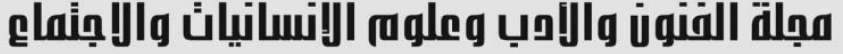

Journal of Arts, Literature, Humanities and Social Sciences www.jalhss.com

\begin{tabular}{|c|c|c|c|c|c|c|c|c|c|c|c|c|c|c|c|}
\hline قليلة & 6 & $\begin{array}{r}53.6 \\
\%\end{array}$ & $\begin{array}{r}2,6 \\
8\end{array}$ & $\% 2,9$ & 62 & $\% 17$ & $\begin{array}{r}36 \\
2\end{array}$ & $\begin{array}{c}\% \\
35,9\end{array}$ & 766 & $\begin{array}{r}34,7 \\
\%\end{array}$ & $\begin{array}{r}74 \\
0\end{array}$ & $\begin{array}{r}9,6 \\
\%\end{array}$ & $\begin{array}{r}20 \\
4\end{array}$ & 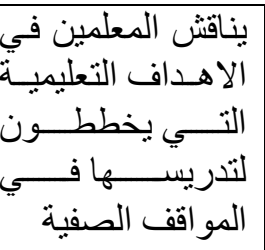 & 6 \\
\hline & قلبيلة & $\begin{array}{r}57.8 \\
\%\end{array}$ & $\begin{array}{r}2.8 \\
9\end{array}$ & $\begin{array}{r}4.64 \\
\%\end{array}$ & & $\begin{array}{r}\% \\
18.45\end{array}$ & & $\begin{array}{r}42.8 \\
\%\end{array}$ & & $\begin{array}{r}30.5 \\
\%\end{array}$ & & $\begin{array}{r}3.3 \\
\%\end{array}$ & & \multicolumn{2}{|c|}{ الدطلبات التخطيطة الكليــة لمجـــال } \\
\hline
\end{tabular}

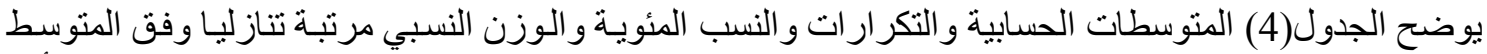

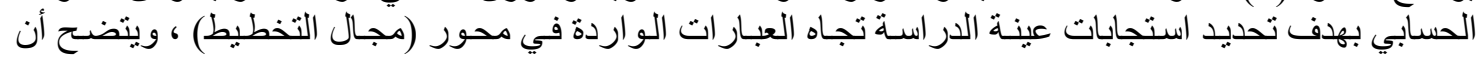

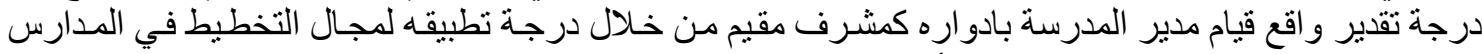

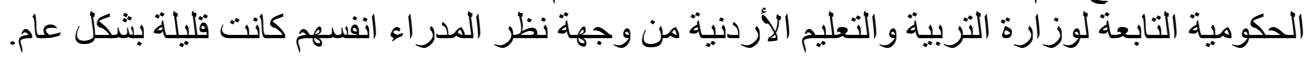

حيث اثشارت المتوسطات الحسابية الخاصة بدرجة استجابة عينة الدراسة إلى حصول الفقرة رقم (1) على القابل

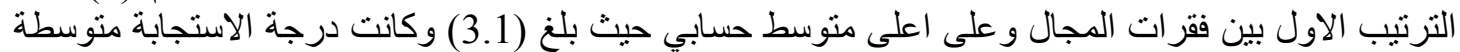

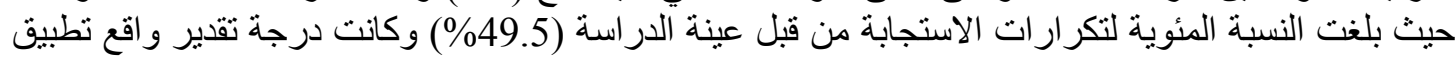

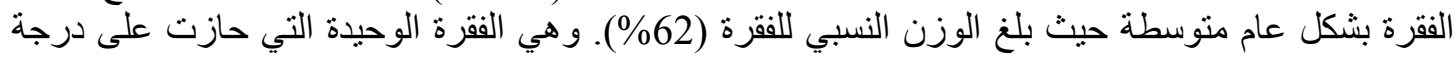

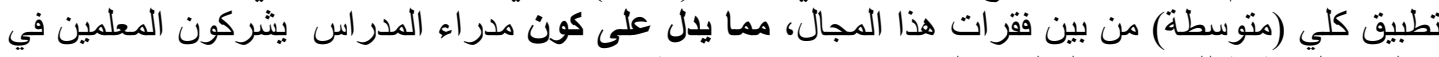
عمليات التخطيط للمهار ات التعليمية المستهدفة بدرجة متوسطة.

وحازت الفقرة رقم (6) على اقل تكر ار ومنوسط حسابي اذ بلغ (2.68) و اشارت نسبة تكر ار الإجابة الخاصة

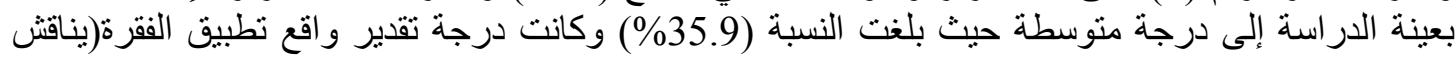

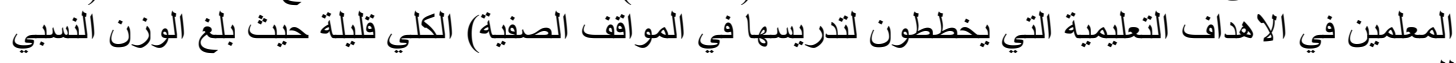

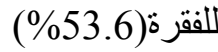

وفيما يتعلق في الدرجة الكلية لدرجة واقع انطباق مجال التخطبط حسب استجابات عبنة الدراسة كانت بدرجة

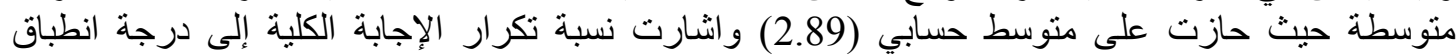

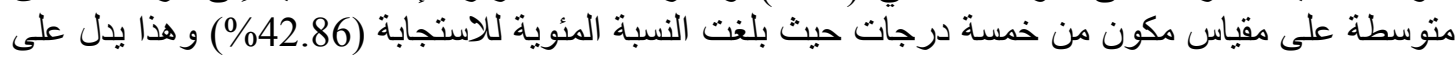

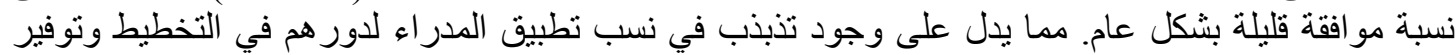
فرصة قلبلة لإشر الك المعلمين في مجال ملثيل التخطيط. 


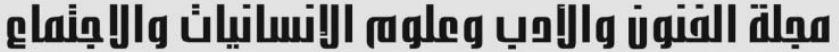

Journal of Arts, Literature, Humanities and Social Sciences www.jalhss.com

يوضح الجدول (5) المتوسطات الحسابية والتكرارات والنسب المئوية والوزن النسبي مرتبة تنازليا وفق المتوسط الحسابي بهدف تحديد استجابات عينة الدراسة تجاه العبارات الواردة العئة في محور (مجال النمو المهني اللمعلمين)

\begin{tabular}{|c|c|c|c|c|c|c|c|c|c|c|c|c|c|c|c|}
\hline \multirow{2}{*}{ 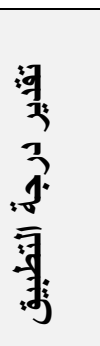 } & \multirow{2}{*}{ 霓: } & \multirow{2}{*}{ 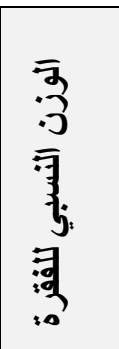 } & \multirow{2}{*}{$\overline{3}$} & \multicolumn{2}{|c|}{ منذفضة } & \multicolumn{2}{|c|}{ منخفضة } & \multicolumn{2}{|c|}{ مبترسطة } & \multicolumn{2}{|c|}{ بارجة عالية } & \multicolumn{2}{|c|}{ بلاجة } & \multirow[b]{2}{*}{ الفقرة } & \multirow{2}{*}{ قر } \\
\hline & & & & \%ن & $ت$ & \%ं & $ت$ & $\%$ & $ت$ & \%ن் & $ت$ & \%ن் & $ت$ & & \\
\hline متوسط & 1 & $\% 67.6$ & 3.38 & $\begin{array}{c}29,3 \\
\%\end{array}$ & $\begin{array}{c}62 \\
6\end{array}$ & $\begin{array}{c}20,1 \\
\%\end{array}$ & $\begin{array}{c}42 \\
8\end{array}$ & $\begin{array}{c}25.5 \\
\%\end{array}$ & $\begin{array}{r}54 \\
4\end{array}$ & $\begin{array}{r}17,3 \\
\%\end{array}$ & $\begin{array}{r}37 \\
0\end{array}$ & $\% 7,8$ & $\begin{array}{r}16 \\
6\end{array}$ & 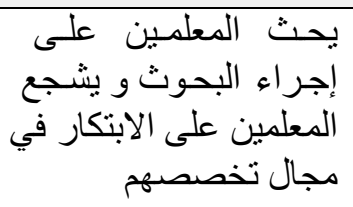 & 7 \\
\hline قليلة & 2 & $\% 56.4$ & 2.95 & $\begin{array}{c}32.1 \\
\%\end{array}$ & $\begin{array}{c}68 \\
6\end{array}$ & $\begin{array}{c}14,9 \\
\%\end{array}$ & $\begin{array}{c}31 \\
8\end{array}$ & $\begin{array}{r}23,6 \\
\%\end{array}$ & $\begin{array}{r}50 \\
4\end{array}$ & $\begin{array}{r}17.8 \\
\%\end{array}$ & $\begin{array}{r}37 \\
9\end{array}$ & $\begin{array}{r}11,6 \\
\%\end{array}$ & $\begin{array}{r}24 \\
7\end{array}$ & 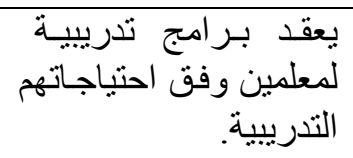 & 12 \\
\hline قليلة & 3 & $\% 53$ & 2.82 & $\% 1$ & 22 & $\begin{array}{c}24,6 \\
\%\end{array}$ & $\begin{array}{c}52 \\
5\end{array}$ & $\begin{array}{r}41,2 \\
\%\end{array}$ & $\begin{array}{r}87 \\
9\end{array}$ & $\begin{array}{r}22,1 \\
\%\end{array}$ & $\begin{array}{r}47 \\
2\end{array}$ & $\begin{array}{r}11,1 \\
\%\end{array}$ & $\begin{array}{r}23 \\
6\end{array}$ & 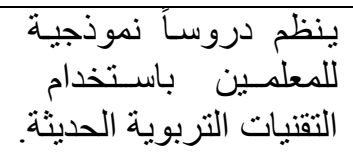 & 8 \\
\hline قليلة & 4 & $\begin{array}{r}51.4 \\
\%\end{array}$ & 2.57 & $\% 5,3$ & $\begin{array}{l}11 \\
3\end{array}$ & $\begin{array}{c}15,7 \\
\%\end{array}$ & $\begin{array}{c}33 \\
6\end{array}$ & $\begin{array}{r}25,6 \\
\%\end{array}$ & $\begin{array}{r}54 \\
7\end{array}$ & $\begin{array}{r}37,7 \\
\%\end{array}$ & $\begin{array}{r}80 \\
5\end{array}$ & $\begin{array}{r}15,6 \\
\%\end{array}$ & $\begin{array}{r}33 \\
3\end{array}$ & 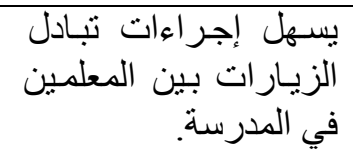 & 11 \\
\hline قليلة & 5 & $\% 50.6$ & 2.53 & $\% 2,6$ & 55 & $\begin{array}{c}14,1 \\
\%\end{array}$ & $\begin{array}{c}30 \\
0\end{array}$ & $\begin{array}{r}29,3 \\
\%\end{array}$ & $\begin{array}{r}62 \\
5\end{array}$ & $\begin{array}{r}42,3 \\
\%\end{array}$ & $\begin{array}{r}90 \\
2\end{array}$ & $\begin{array}{r}11,8 \\
\%\end{array}$ & $\begin{array}{r}25 \\
2\end{array}$ & 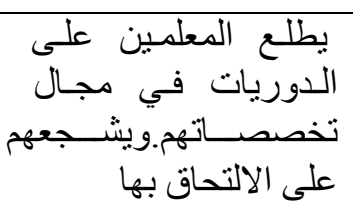 & 10 \\
\hline قليلة & 6 & $\% 50$ & 2.50 & $\% 1,3$ & 28 & $\begin{array}{c}10,4 \\
\%\end{array}$ & $\begin{array}{c}22 \\
1\end{array}$ & $\begin{array}{r}42,4 \\
\%\end{array}$ & $\begin{array}{r}90 \\
5\end{array}$ & $\% 29$ & $\begin{array}{r}61 \\
9\end{array}$ & $\begin{array}{r}16,9 \\
\%\end{array}$ & $\begin{array}{r}36 \\
1\end{array}$ & تربوية للمعلىين الجنيم برد امج & 9 \\
\hline
\end{tabular}




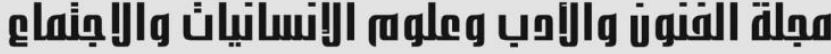

Journal of Arts, Literature, Humanities and Social Sciences www.jalhss.com

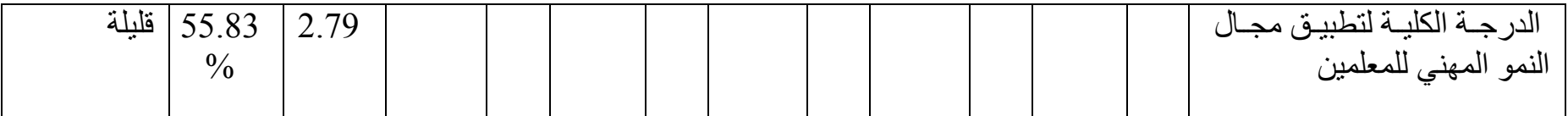

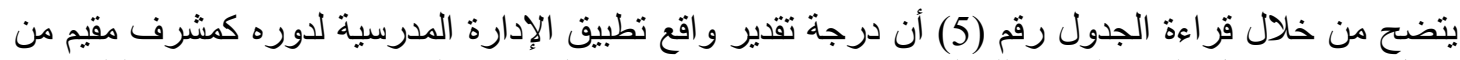

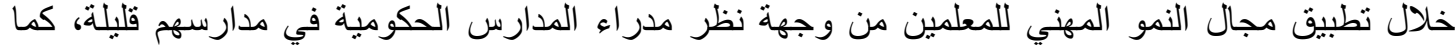
اثتارت لها المتوسطات الحسابية الخاصة بدرجة استجابة عينة الدراسة الخاصة بفقرات مجال النمو المهني

للمعلمين.

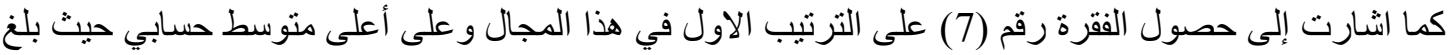

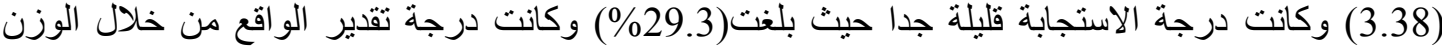

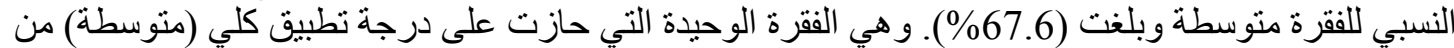

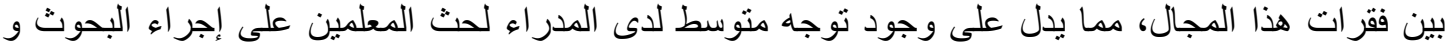

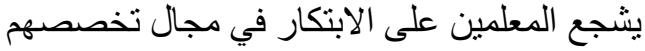

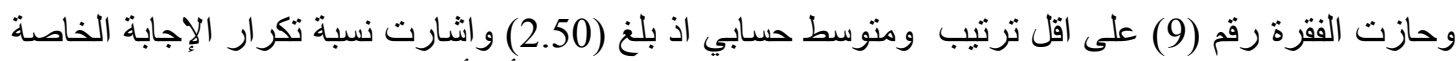

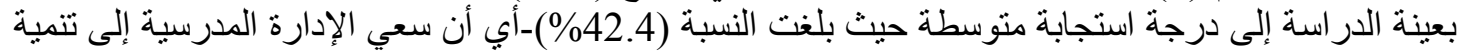

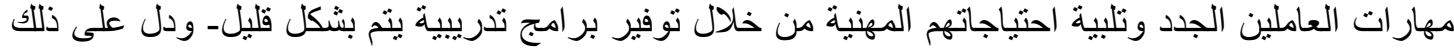
واقع درجة التطبيق القليلة فقد بلغ الوزن النسبي للفقرة (50\%).

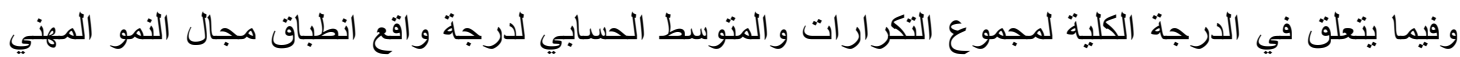

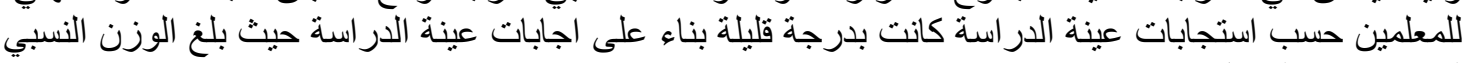
كافة فقرات المجال(55.8\%)

\section{جدول (6) مجال تطوير العلاقات الإنسانية}

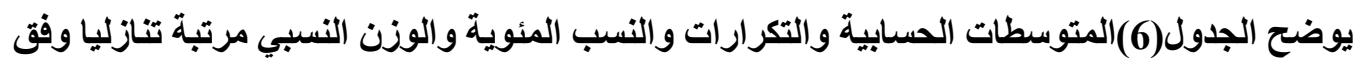
المتوسط الحسابي بهدف تحديد استجابات عينة الدراسة تجاه العبارات الواردة في محور (مجال تطوير العلاقات (الإنسانية)

\begin{tabular}{|c|c|c|c|c|c|c|c|c|c|c|c|c|c|c|c|}
\hline \multirow{2}{*}{ 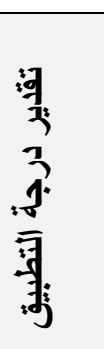 } & \multirow{2}{*}{ 影 } & \multirow{2}{*}{ 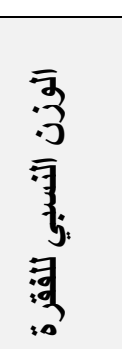 } & \multirow{2}{*}{ 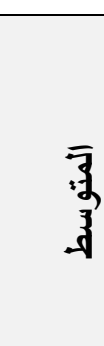 } & \multicolumn{2}{|c|}{ منخفضة } & \multicolumn{2}{|c|}{ منخفضة } & \multicolumn{2}{|c|}{ منوسطة } & \multicolumn{2}{|c|}{ بدرجة عالية } & \multicolumn{2}{|c|}{ بلالية } & \multirow[b]{2}{*}{ الفقرة } & \\
\hline & & & & \%ن & ت & \% & ت & \% & ت & \% & $ت$ & \%ن & $ت$ & & قم \\
\hline متوسط & 1 & $\% 67.6$ & 3.38 & $\begin{array}{c}29,3 \\
\%\end{array}$ & $\begin{array}{c}62 \\
6\end{array}$ & $\begin{array}{c}20,1 \\
\%\end{array}$ & $\begin{array}{c}42 \\
8\end{array}$ & $\begin{array}{c}25.5 \\
\%\end{array}$ & $\begin{array}{r}54 \\
4\end{array}$ & $\begin{array}{r}17,3 \\
\%\end{array}$ & $\begin{array}{r}37 \\
0\end{array}$ & $\% 7,8$ & $\begin{array}{r}16 \\
6\end{array}$ & الاجتماعية بحاجات المعلمين & 15 \\
\hline
\end{tabular}




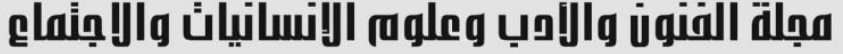

Journal of Arts, Literature, Humanities and Social Sciences www.jalhss.com

\begin{tabular}{|c|c|c|c|c|c|c|c|c|c|c|c|c|c|c|c|}
\hline قليلة & 10 & $\% 54$ & 2.70 & $\% 3,2$ & 68 & $\% 7,5$ & $\begin{array}{c}16 \\
0\end{array}$ & $\begin{array}{c}49,2 \\
\%\end{array}$ & $\begin{array}{l}10 \\
50\end{array}$ & $\begin{array}{c}36,5 \\
\%\end{array}$ & $\begin{array}{c}77 \\
8\end{array}$ & $\% 3,7$ & 78 & الشعتر المعلمون بأهميـة & 18 \\
\hline قليلة & 11 & $\% 53.6$ & 2.68 & $\% 3,4$ & 72 & $\begin{array}{c}36.7 \\
\%\end{array}$ & $\begin{array}{c}37 \\
8\end{array}$ & $\begin{array}{c}32,7 \\
\%\end{array}$ & $\begin{array}{c}69 \\
8\end{array}$ & $\begin{array}{c}17.7 \\
\%\end{array}$ & $\begin{array}{l}78 \\
2\end{array}$ & $\% 9,2$ & $\begin{array}{c}20 \\
2\end{array}$ & 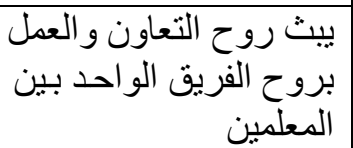 & 8 \\
\hline قليلة & 12 & $\% 53.2$ & 2.66 & $\% 0,8$ & 18 & $\begin{array}{c}17,5 \\
\%\end{array}$ & $\begin{array}{c}37 \\
3\end{array}$ & $\begin{array}{c}40,4 \\
\%\end{array}$ & $\begin{array}{c}86 \\
2\end{array}$ & $\begin{array}{c}30,1 \\
\%\end{array}$ & $\begin{array}{c}64 \\
2\end{array}$ & $\begin{array}{c}11,2 \\
\%\end{array}$ & $\begin{array}{c}23 \\
9\end{array}$ & 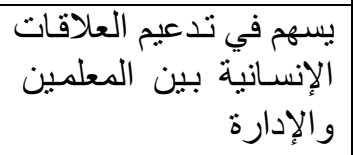 & 14 \\
\hline قلبلة & 12 & $\% 53.2$ & 2.66 & $\% 1$ & 22 & $\begin{array}{c}18,4 \\
\%\end{array}$ & $\begin{array}{c}39 \\
3\end{array}$ & $\begin{array}{c}37,3 \\
\%\end{array}$ & $\begin{array}{c}79 \\
7\end{array}$ & $\begin{array}{c}32,1 \\
\%\end{array}$ & $\begin{array}{c}68 \\
4\end{array}$ & $\begin{array}{c}11,2 \\
\%\end{array}$ & $\begin{array}{c}23 \\
8\end{array}$ & 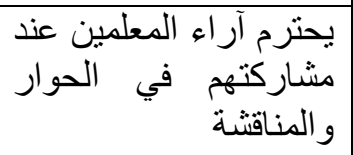 & 16 \\
\hline قليلة & 13 & $\% 51$ & 2.55 & $\% 0,7$ & 16 & $\% 8,6$ & $\begin{array}{c}18 \\
3\end{array}$ & $\begin{array}{c}45.8 \\
\%\end{array}$ & $\begin{array}{c}87 \\
0\end{array}$ & $\begin{array}{c}40.3 \\
\%\end{array}$ & $\begin{array}{c}96 \\
6\end{array}$ & $\% 4,6$ & 99 & 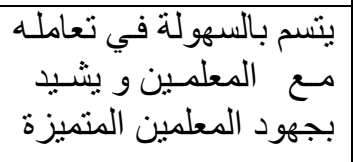 & 17 \\
\hline & قليلة & $\begin{array}{c}55.83 \\
\%\end{array}$ & 2.79 & & & & & & & & & & & 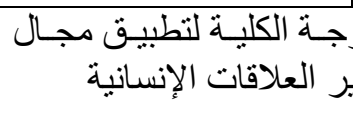 & \\
\hline
\end{tabular}

يتضح من خـلال قر اءة الجدول رقم (6) أن درجـة تقدير الو اقع لدور مدر اء المدارس في تنفيذ مهام المشرف

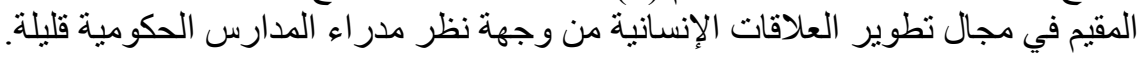

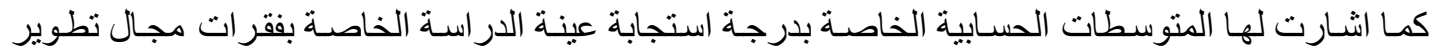

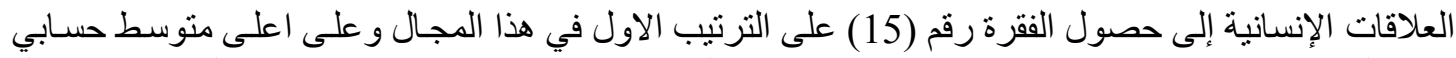

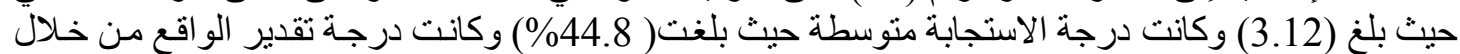
الوزن النسبي للفقرة متوسطة وبلغت(

وحازت الفقرة رقم (17) على اقل ترتيب ومتوسط حسابي اذ بلغ (2.55) و اشتارت نسبة تكر ار الإجابة الخاصة

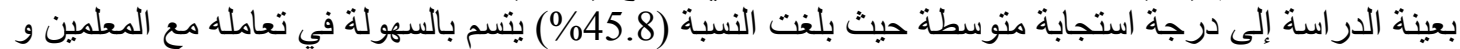

يثيد بجهود المعلمين المتميزة.-ودل على ذللك واقع درجة التطبيق القليلة فقد بلغ الوزن النسبي للفقرة (51\%).

وفيما يتعلق في الدرجة الكلية لمجموع التكرارات والنسبة المئوية من مجموع عينة الدراسة لدرجة واقع انطباق

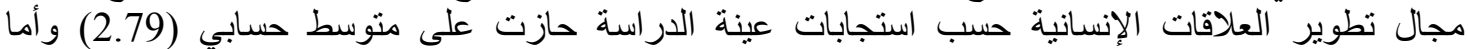

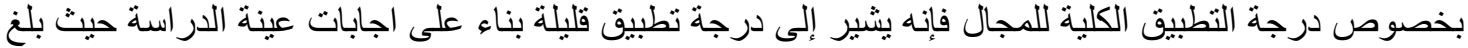
الوزن النسبي لكافة فقرات المجال (55.8\%) 


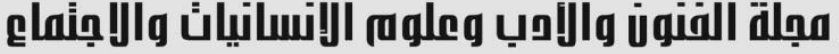

Journal of Arts, Literature, Humanities and Social Sciences www.jalhss.com

يوضح الجدول (7) المتوسطات الحسابية والتكرارات والنسب المئوية والوزن النسبي مرتبة تنازليا وفق

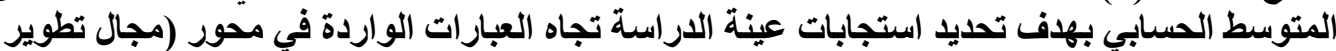

المناهج)

\begin{tabular}{|c|c|c|c|c|c|c|c|c|c|c|c|c|c|c|c|}
\hline \multirow[t]{2}{*}{ 交 } & \multirow[t]{2}{*}{ 㐨: } & \multirow[t]{2}{*}{$\begin{array}{l}\overline{3} \\
.3 \\
\overline{7} \\
3\end{array}$} & \multirow[t]{2}{*}{ 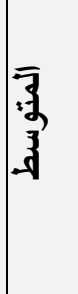 } & \multicolumn{2}{|c|}{ منخفضة } & \multicolumn{2}{|c|}{ منففضة } & \multicolumn{2}{|c|}{ متوسطة } & \multicolumn{2}{|c|}{ بلرجة عالية } & \multicolumn{2}{|c|}{ عالية } & \multirow[t]{2}{*}{ الفقرة } & \multirow[t]{2}{*}{ الرقم } \\
\hline & & & & $\%$ & ت & \%ن் & $ت$ & \%ن் & $ت$ & \%ن & $ت$ & $\%$ & $ت$ & & \\
\hline قليلة & 1 & $\% 56$ & $\begin{array}{c}2.8 \\
0\end{array}$ & $\% 0,7$ & 16 & $\begin{array}{c}35,4 \\
\%\end{array}$ & $\begin{array}{c}75 \\
6\end{array}$ & $\% 28$ & $\begin{array}{c}59 \\
8\end{array}$ & $\begin{array}{c}28.7 \\
\%\end{array}$ & $\begin{array}{c}61 \\
3\end{array}$ & $\% 7,1$ & $\begin{array}{c}15 \\
1\end{array}$ & الععامة للمناهج وضيحد الأهداف للمعلمين & 22 \\
\hline قليلة & 2 & $\begin{array}{c}55.8 \\
\%\end{array}$ & $\begin{array}{c}2.7 \\
9\end{array}$ & $\% 5,5$ & $\begin{array}{c}11 \\
7\end{array}$ & $\begin{array}{c}12,5 \\
\%\end{array}$ & $\begin{array}{c}26 \\
6\end{array}$ & $\begin{array}{c}41,5 \\
\%\end{array}$ & $\begin{array}{c}88 \\
5\end{array}$ & $\begin{array}{c}39.1 \\
\%\end{array}$ & $\begin{array}{c}83 \\
5\end{array}$ & $\% 1,5$ & 31 & 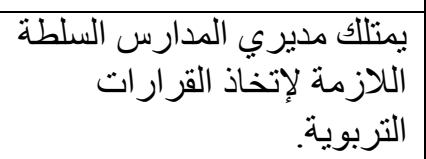 & 24 \\
\hline قلبلة & 3 & $\begin{array}{c}52.4 \\
\%\end{array}$ & $\begin{array}{c}2.6 \\
2\end{array}$ & $\% 3,6$ & 76 & $\% 8,8$ & $\begin{array}{c}18 \\
7\end{array}$ & $\begin{array}{c}41,3 \\
\%\end{array}$ & $\begin{array}{c}88 \\
1\end{array}$ & $\begin{array}{c}39,6 \\
\%\end{array}$ & $\begin{array}{c}84 \\
5\end{array}$ & $\% 6,8$ & $\begin{array}{c}14 \\
5\end{array}$ & أهدافه يساعد المتعمين على تحليل & 20 \\
\hline قليلة & 4 & $\% 52$ & $\begin{array}{c}2.6 \\
0\end{array}$ & $\% 5,5$ & $\begin{array}{c}11 \\
8\end{array}$ & $\% 5,5$ & $\begin{array}{c}11 \\
8\end{array}$ & $\begin{array}{c}46,3 \\
\%\end{array}$ & $\begin{array}{c}98 \\
9\end{array}$ & $\begin{array}{c}29,1 \\
\%\end{array}$ & $\begin{array}{c}62 \\
0\end{array}$ & $\begin{array}{c}13,5 \\
\%\end{array}$ & $\begin{array}{c}28 \\
9\end{array}$ & طعرل على عقد ندوات لتحديد & 19 \\
\hline قليلة & 5 & $\begin{array}{c}51.4 \\
\%\end{array}$ & $\begin{array}{c}2.5 \\
7\end{array}$ & $\% 7,8$ & $\begin{array}{c}16 \\
6\end{array}$ & $\begin{array}{c}11,1 \\
\%\end{array}$ & $\begin{array}{c}23 \\
6\end{array}$ & $\begin{array}{c}30,1 \\
\%\end{array}$ & $\begin{array}{c}64 \\
2\end{array}$ & $\begin{array}{c}32,7 \\
\%\end{array}$ & $\begin{array}{c}69 \\
7\end{array}$ & $\begin{array}{c}18,4 \\
\%\end{array}$ & $\begin{array}{c}39 \\
3\end{array}$ & 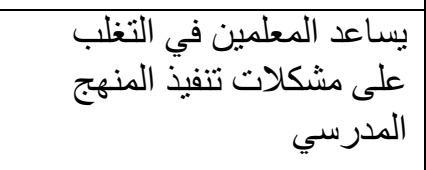 & 21 \\
\hline قليلة & 6 & $\begin{array}{c}47.6 \\
\%\end{array}$ & $\begin{array}{c}2.3 \\
8\end{array}$ & $\% 0,7$ & 16 & $\begin{array}{c}10,9 \\
\%\end{array}$ & $\begin{array}{c}23 \\
2\end{array}$ & $\begin{array}{c}30,1 \\
\%\end{array}$ & $\begin{array}{c}64 \\
3\end{array}$ & $\begin{array}{c}42,7 \\
\%\end{array}$ & $\begin{array}{c}91 \\
1\end{array}$ & $\begin{array}{c}15,6 \\
\%\end{array}$ & $\begin{array}{c}33 \\
2\end{array}$ & 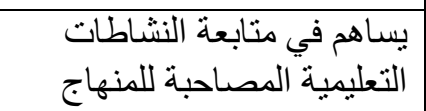 & 23 \\
\hline & & $\begin{array}{c}52.5 \\
\%\end{array}$ & $\begin{array}{c}2.6 \\
3\end{array}$ & & & & & & & & & & & جذة الكلية لمجال تطوير المناهج & 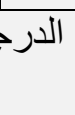 \\
\hline
\end{tabular}

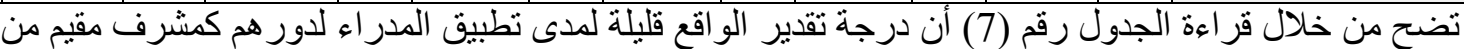

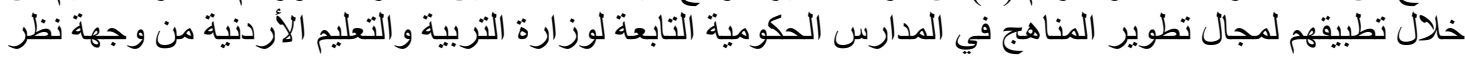
مدر اء المدارس الحكومية انفسهر.

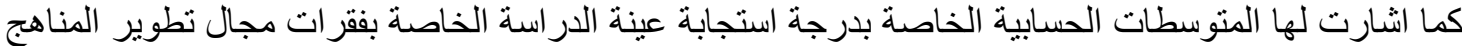
إلى حصول الفقرة رقم (22) على الترتيب الاول في هذا المجال و على العلى اعلى متوسط حسابي حيث بلغ بلغ (2.80) وكانت درجة الاستجابة منخفضة حيث بلغت ( 35.4\%) وكانت درجة تقدير تطبيق الواقع من خلال الوزن حلن الون 


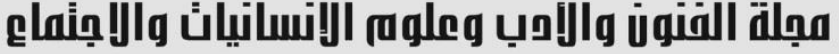

Journal of Arts, Literature, Humanities and Social Sciences www.jalhss.com

Volume (71) September 2021

\section{¿ALHSS}

النسبي للفقرة قليلة وبلغت( 56\%). مما يدل على قلة قيام إدارة المدرسة بتوضيح الأهداف العامة للمناهج وتحديدها للمعلمين.

وحازت الفقرة رقم (23) على اقل ترتيب ومتوسط حسابي اذ بلغ (2.38) واشارت نسبة تكر ار الإجابة الخاصة بعينة الدر اسة إلى درجة استجابة عالية حيث بلغت النسبة (42.7\% قليلة جداً فقد بلغ الوزن النسبي للفقرة (47.6\%) مما يدل على انس نسبة قليلة جدا من الددراء يساهم في متابعة النشاطات التعليمية المصاحبة للمنهاج.

وفيما يتعلق في الدرجة الكلية لمجموع التكرارات و المتوسط الحسابي لدرجة و اقع انطباق مجال تطوير المناهج

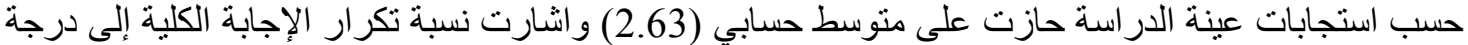
استجابة منوسطة على مقياس مكون من خمس درجات حيث بلغت النسبة المئوية للاستجابة (42.7\%).

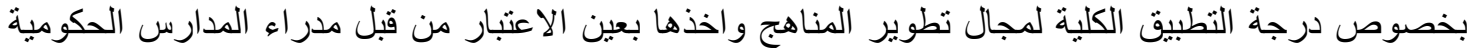

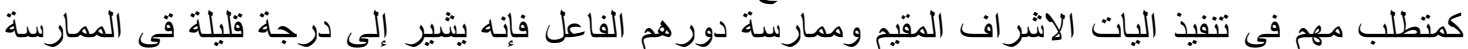

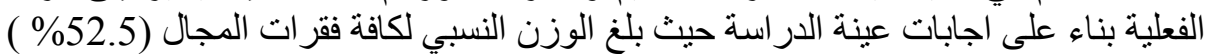
5- - 5دول(8) مجال التقييم

يوضح الجدول (8) المتوسطات الحسابية والتكرات والنسب المئوية والوزن النسبي مرتبة تنازليا وفق المتوسط الحسابي بهاف تحديد استجابات عينة الاراسة تجاه العبارات الواردة في محور (مجال التقييم)

\begin{tabular}{|c|c|c|c|c|c|c|c|c|c|c|c|c|c|c|c|}
\hline \multirow[t]{2}{*}{ 方 } & \multirow[t]{2}{*}{ 牙 } & \multirow[t]{2}{*}{$\begin{array}{l}\overline{3} \\
.3 \\
\overline{7} \\
3\end{array}$} & \multirow[t]{2}{*}{$\overline{3}$} & \multicolumn{2}{|c|}{ منفضضة } & \multicolumn{2}{|c|}{ منخفضة } & \multicolumn{2}{|c|}{ متوسطة } & \multicolumn{2}{|c|}{ بلرجة عالية } & \multicolumn{2}{|c|}{ علرجة } & \multirow[t]{2}{*}{ 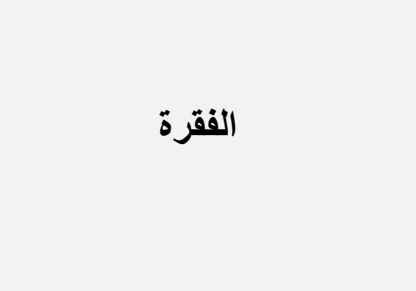 } & \multirow[t]{2}{*}{ 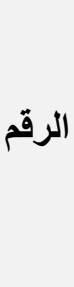 } \\
\hline & & & & $\%$ & $ت$ & $\%$ & ت & \%ن & $ت$ & $\%$ & $ت$ & $\%$ & ت & & \\
\hline طنوس & 1 & $\% 62.2$ & $\begin{array}{c}3.1 \\
1\end{array}$ & $\% 12,3$ & $\begin{array}{c}26 \\
2\end{array}$ & $\begin{array}{c}21,6 \\
\%\end{array}$ & $\begin{array}{c}46 \\
1\end{array}$ & $\begin{array}{c}37,2 \\
\%\end{array}$ & $\begin{array}{c}79 \\
4\end{array}$ & $\begin{array}{c}23,6 \\
\%\end{array}$ & $\begin{array}{c}50 \\
3\end{array}$ & $\% 5,3$ & $\begin{array}{c}11 \\
4\end{array}$ & 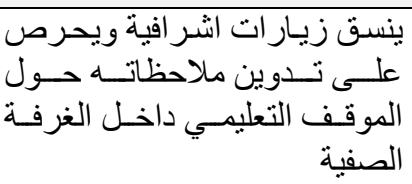 & 26 \\
\hline متوس & 2 & $\% 61.8$ & $\begin{array}{c}3.0 \\
9\end{array}$ & $\% 6,7$ & $\begin{array}{c}14 \\
3\end{array}$ & $\begin{array}{c}26,8 \\
\%\end{array}$ & $\begin{array}{c}57 \\
2\end{array}$ & $\begin{array}{c}39,5 \\
\%\end{array}$ & $\begin{array}{c}84 \\
3\end{array}$ & $\% 23$ & $\begin{array}{c}49 \\
1\end{array}$ & $\% 4$ & 85 & الزينح المعلمين نسخة عن تقريـر & 28 \\
\hline متوسد & 3 & $\% 60.6$ & $\begin{array}{c}3.0 \\
3\end{array}$ & $\% 10,3$ & $\begin{array}{c}22 \\
0\end{array}$ & $\begin{array}{c}31,8 \\
\%\end{array}$ & $\begin{array}{c}67 \\
9\end{array}$ & $\begin{array}{l}25.5 \\
\%\end{array}$ & $\begin{array}{c}54 \\
4\end{array}$ & $\begin{array}{c}22,1 \\
\%\end{array}$ & $\begin{array}{c}47 \\
2\end{array}$ & $\begin{array}{c}10,3 \\
\%\end{array}$ & $\begin{array}{c}21 \\
9\end{array}$ & يتابع انجازات المعلمين ويدعمها & 25 \\
\hline
\end{tabular}




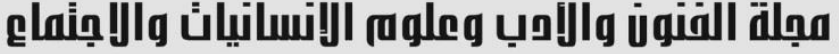

Journal of Arts, Literature, Humanities and Social Sciences www.jalhss.com

العدد) (71) سبتمبر 2021

\begin{tabular}{|c|c|c|c|c|c|c|c|c|c|c|c|c|c|c|c|}
\hline قليلة & 4 & $\% 57.6$ & $\begin{array}{c}2.8 \\
8\end{array}$ & $\% 10,2$ & $\begin{array}{c}21 \\
7\end{array}$ & $\begin{array}{c}35,3 \\
\%\end{array}$ & $\begin{array}{c}75 \\
4\end{array}$ & $\begin{array}{c}16.4 \\
\%\end{array}$ & $\begin{array}{c}34 \\
9\end{array}$ & $\begin{array}{c}27,6 \\
\%\end{array}$ & $\begin{array}{c}59 \\
0\end{array}$ & $\begin{array}{c}10,5 \\
\%\end{array}$ & $\begin{array}{c}22 \\
4\end{array}$ & 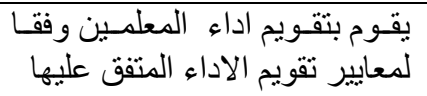 & 27 \\
\hline قليلة & 5 & $\begin{array}{c}57.54 \\
\%\end{array}$ & $\begin{array}{c}2.8 \\
7\end{array}$ & $\% 9,9$ & $\begin{array}{c}21 \\
2\end{array}$ & $\begin{array}{c}39,7 \\
\%\end{array}$ & $\begin{array}{c}84 \\
8\end{array}$ & $\begin{array}{c}35,6 \\
\%\end{array}$ & $\begin{array}{c}76 \\
0\end{array}$ & $\begin{array}{c}12.2 \\
\%\end{array}$ & $\begin{array}{c}26 \\
0\end{array}$ & $\% 2,5$ & 54 & الذاتيـيع المعلمـين علــى التقيــيم & 29 \\
\hline & & $\begin{array}{c}52.5 \\
\%\end{array}$ & $\begin{array}{c}2.6 \\
3\end{array}$ & & & & & & & & & & & \multicolumn{2}{|c|}{ الدرجة الكلية لمجال تطوير المناهج } \\
\hline
\end{tabular}

يتضح من خلال قراءة الجدول رقم (8) أن درجة تقدير الواقع في مجال التقييم قليلة لمدى ممارسة مدراء

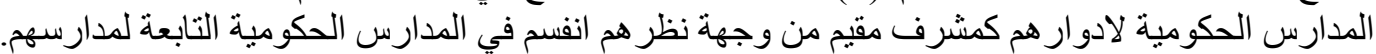

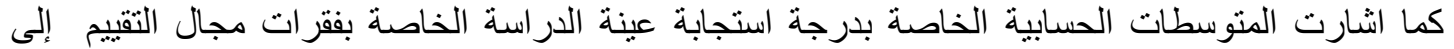
حصول الفقرة رقم (26) على الترتيب الاول في هذا المجال و على اعلى متوسط حسابي حيث بلغ الغ (3711)

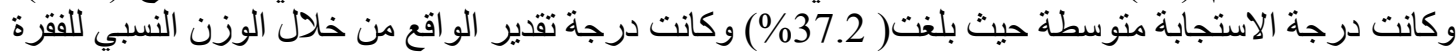

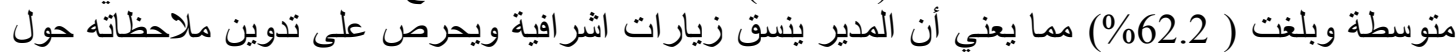

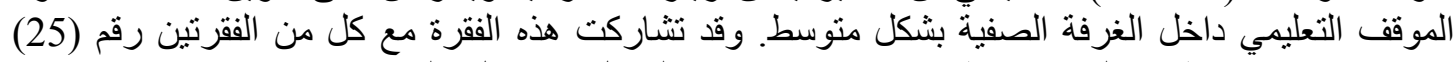

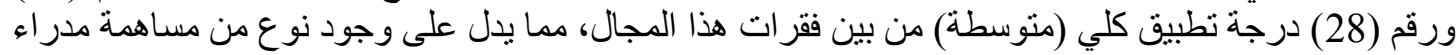
المدارس الحكومية في ممارسة التقييم.

وحازت الفقرة رقم (30) على اقل ترتيب ومتوسط حسابي اذ بلغ (2.79) و اشارت نسبة تكر ار الإجابة الخاصة

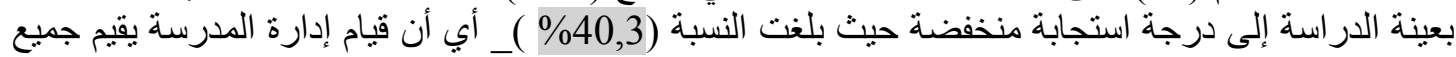

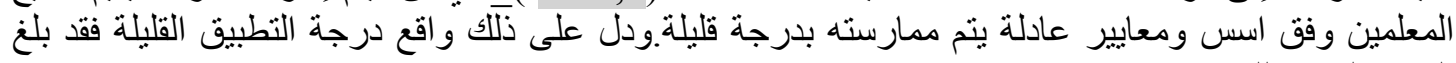

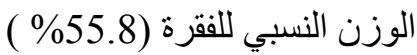

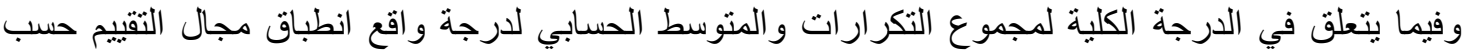

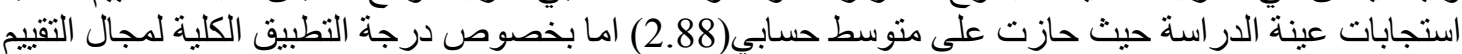

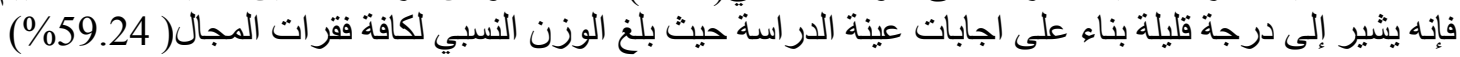

جدول (9) خلاصة نتائج الارجة الكلية لمتطلبات مدى تطبيق مدراء المدارس الحكومية لاور المشرف المقيم في مدارسهم من وجهة نظر مدراء المدارس انفسهم، :

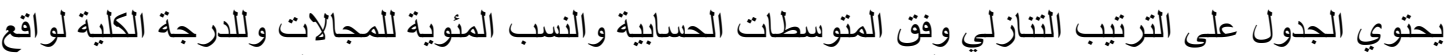

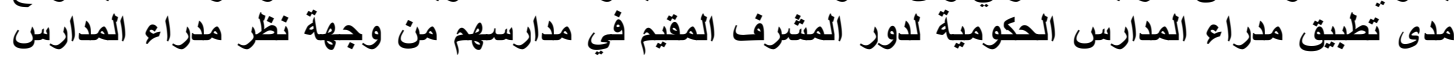
انفسهم، وذللك كما هو موضح في الجدول الاتي : 


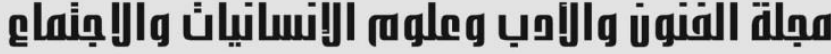

Journal of Arts, Literature, Humanities and Social Sciences www.jalhss.com

\begin{tabular}{|c|c|c|c|c|c|}
\hline الترتيب & التطبيق & النسبي & الاستجابة* & المجال & الترتيب \\
\hline 1 & ق ق قليلة & $\% 57.8$ & 2.89 & التخطيط & \\
\hline 5 & 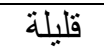 & $\% 51.4$ & 2.57 & التقويم & \\
\hline 3 & قليلة & $\% 55.83$ & 2.79 & تطوير العلاقات الانسانية & \\
\hline 2 & 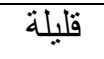 & $\% 56.75$ & 2.84 & النمو المهني للمعلمين & \\
\hline 4 & 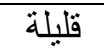 & $\% 52.5$ & 2.63 & تطوير المناهج & \\
\hline & & & & \multicolumn{2}{|c|}{ الدرجة الكلية لكافة المجالات } \\
\hline
\end{tabular}

ومن اجل تفسير النتائج اعتمد الباحث مقياس ليكرت الخماسي للحصول على النسب المئوية الآتية:

\begin{tabular}{|c|c|}
\hline درجة الو اقع & الوزن النسبي \\
\hline درجة و اقع كبيرة جدا & 80\% فأكثر \\
\hline درجة و اقع كبيرة & $\% 79.9-70 \%$ \\
\hline درجة و اقع متوسطة & $\% 69.9-\% 60$ \\
\hline درجة و اقع قليلة & $\% 59.9-50 \%$ \\
\hline درجة و اقع قليلة جدا & اقل من\% 50 \\
\hline
\end{tabular}

يتضح من دراسة الجدول السابق رقم (9) أن درجة التقدير في مجال التخطيط حازت على اعلى ترتيب بين بـاقي

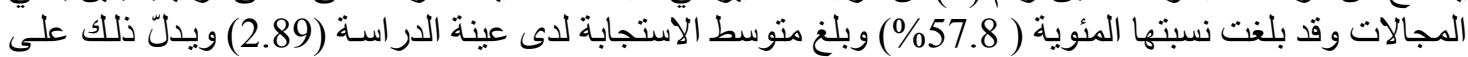

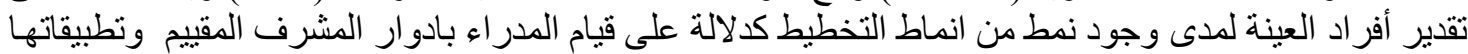
في مدارسهم.

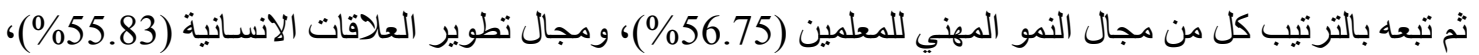

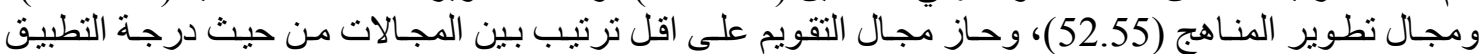
بمتوسط حسابي لاستجابة عينة الدر اسة بلغت (51.4) و 


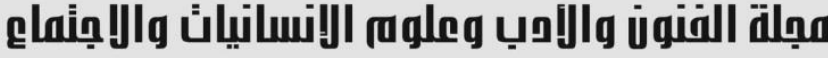

Journal of Arts, Literature, Humanities and Social Sciences www.jalhss.com

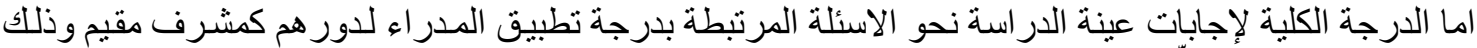

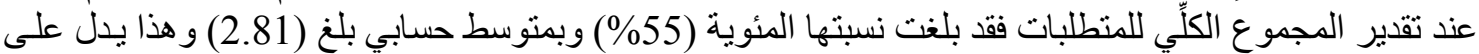
درجة تقدير قليلة لو اقع درجة تطبيق مجالات تفعيل الادوار الاشرفية للمدير كمشرف مقيم ومنطلباتها .

يتبين لنا من قر اءة الجدول(8) أن الفروق التي ظهرت لدى عينة الدراسة حول درجة تقدير هم لمدى تحقق منطلبات

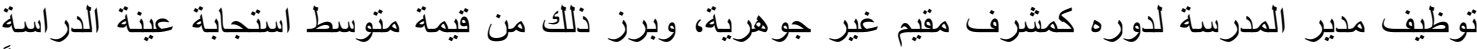

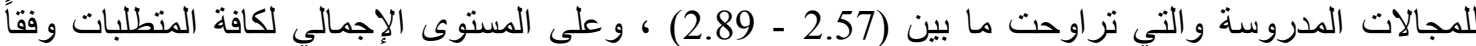
لإجابات أفراد عينة الدراسة، ورذا يدلّ على أن تقدير أفراد العينة لتحقق المنطلبات متقاربة رغم الختلاف

المتغيرات بينه.

ومن الممكن أن نعزو نتيجة درجة التطبيق القليلة من قبل المدراء لادوارهم كمشرفين مقيمين في مدارسهم على

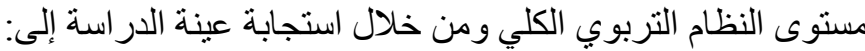

1- عدم احساس العاملين بوجود وضوح للرؤية لدى الجهات المسؤولة عن تنفيذ وتطبيق تلك الادوار الاشر افية

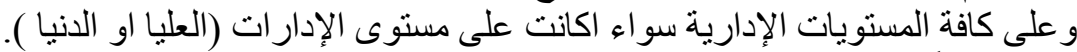

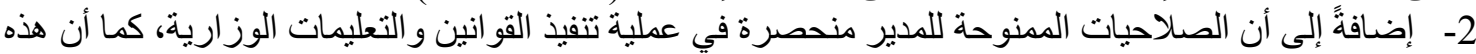
المهمات هي واحدة سو اء أكانت المدرسة ابتدائية ام ثانوية وفي أبي منطقة جغر افية.

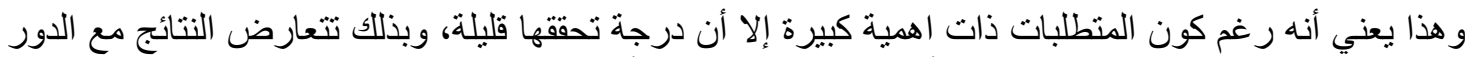

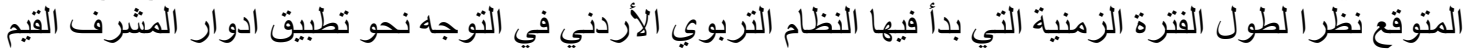
المنوطة بمدر اء المدارس الحكومية الزية الزية

تحليل البيانات الخاصة بالفرضية الثانية ومناقثة النتائج ثانياً فحص الفرضية الصفرية التالية:

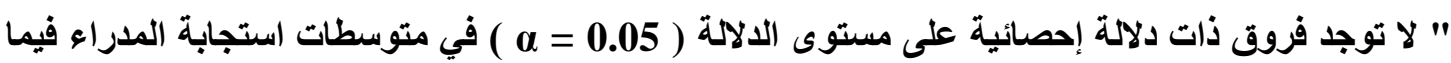

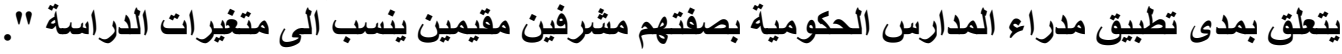

\section{حيث ينبثق عنها الفرضيات الفرعية التالية:}

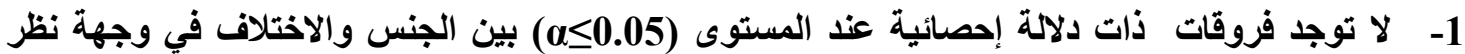

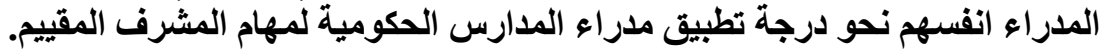

من اجل فحص هذه الفرضية نم استخدام المتوسطات الحسابية واختبار (t-test) وتم اعتماد النتائج كما هو

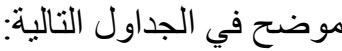

جدول رقم ( 10) نتائج اختبار t للقروق بين إجابات المبحوثين تعزى لمتغير الجنس

\begin{tabular}{|c|c|c|c|c|c|c|c|c|c|}
\hline \multirow{2}{*}{ مستوى } & \multicolumn{2}{|c|}{ مجال الثقة (95\%) } & \multirow{2}{*}{$\begin{array}{r}\text { دلالة } \\
\text { t }\end{array}$} & \multirow[t]{2}{*}{ قيمة } & \multirow{2}{*}{ 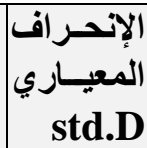 } & \multirow{2}{*}{ الحستوسي | المتوس } & \multirow[t]{2}{*}{ العدد } & \multirow{2}{*}{ الجنس } & \multirow[t]{2}{*}{ المجالات } \\
\hline & اعلى & ادنى & & & & & & & \\
\hline دال & 0.40 & 0.28 & 0.00 & 11.33 & 0.69 & 3.11 & 840 & ذكر & التخطيط \\
\hline دال & 0.40 & 0.28 & 0.00 & 11.23 & 0.66 & 2.77 & 1294 & أنثى & \\
\hline
\end{tabular}




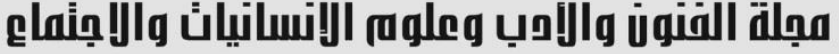

Journal of Arts, Literature, Humanities and Social Sciences www.jalhss.com

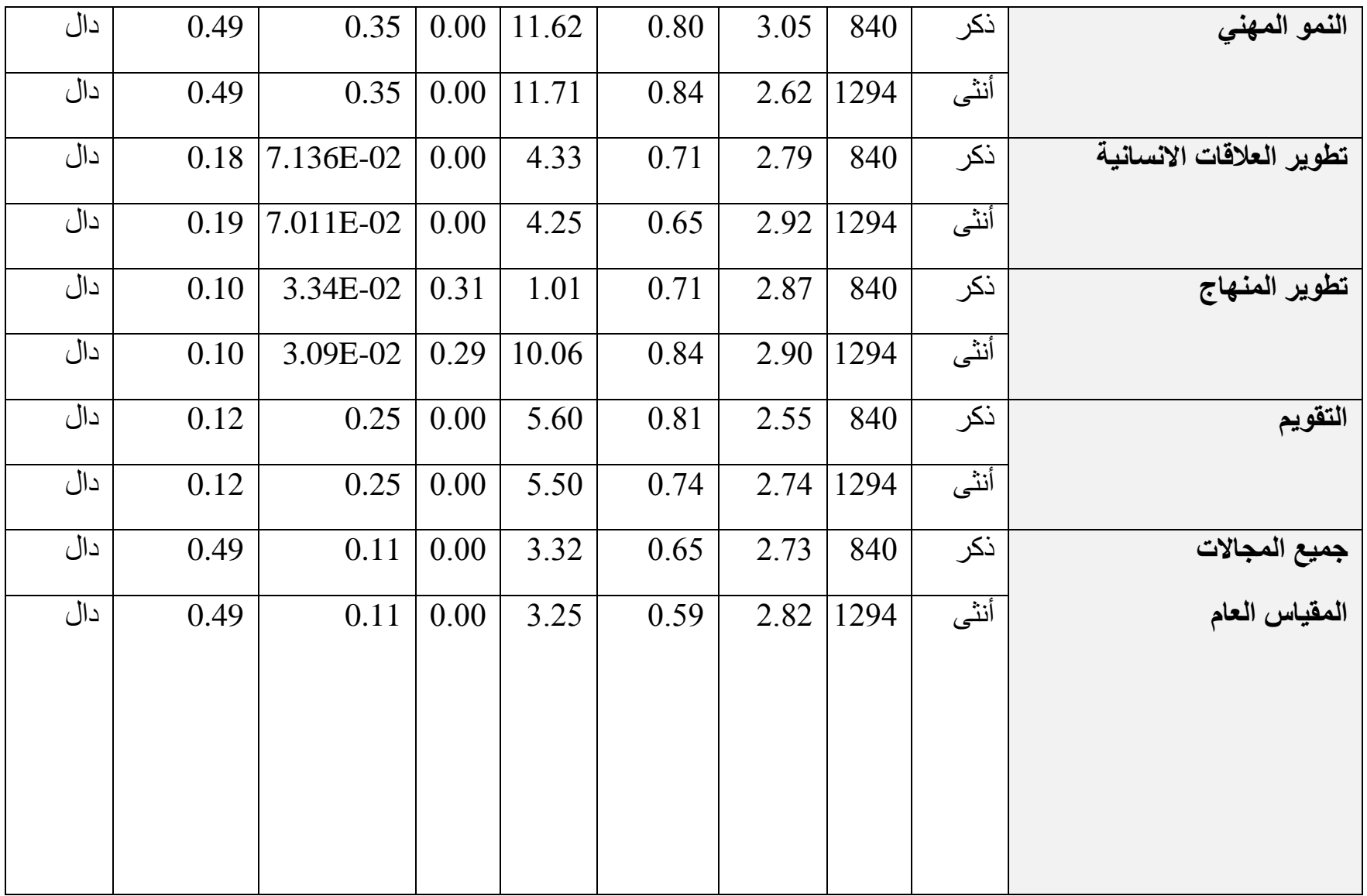

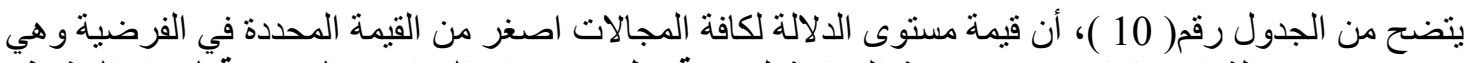

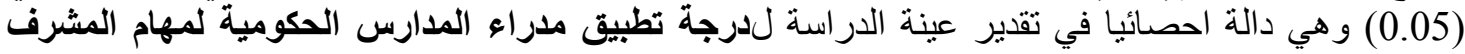

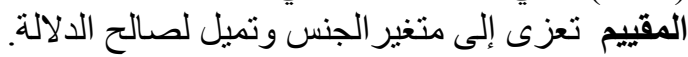

حيث يتضح من الجدول أن المتوسط الحسابي لإستجابة الاناث في كافة المتطلبات أعلى منه عند الذكور، اي يميل المتوسط الحسابي لصنالح الأناث. لذا فإننا نرفض الفئ لفر الفرضية

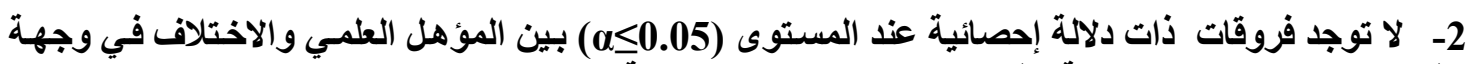

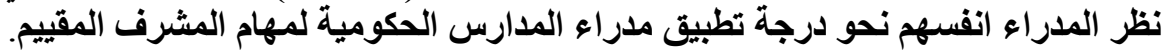

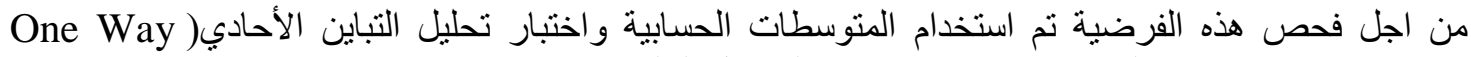
ANOVA) وتم اعتماد النتائج كما هو موضح في الجداول النالية: 


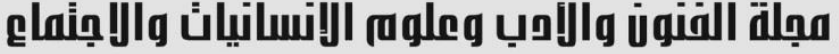

Journal of Arts, Literature, Humanities and Social Sciences www.jalhss.com

الجدول (11 ) المتوسطات الحسابية من وجهة نظر عينة الدراسة تبعاً لمتغير المؤهل العلمي

\begin{tabular}{|c|c|c|c|c|c|c|}
\hline \multirow[t]{2}{*}{\begin{tabular}{|l} 
Std.D \\
للمجموع
\end{tabular}} & \multirow[t]{2}{*}{ اللمجلي } & \multicolumn{2}{|c|}{ ل دراسات عليا } & \multicolumn{2}{|c|}{ البكالوريوس + ادبلوم مهني او } & \multirow[t]{2}{*}{ المجالات } \\
\hline & & المتوسط & | & المتوسط & \begin{tabular}{|} 
العدد \\
N
\end{tabular} & \\
\hline 0.699 & 2.91 & 2.90 & 495 & 3.04 & 1334 & التخطيط \\
\hline 0.853 & 2.79 & 2.72 & 495 & 3.04 & 1334 & النمو المهني \\
\hline 0.680 & 2.84 & 2.71 & 495 & 3.08 & 1334 & تطوير العلاقات الانسانية \\
\hline 0.754 & 2.63 & 2.48 & 495 & 2.80 & 1334 & تظوير المناهج \\
\hline 0.796 & 2.88 & 2.45 & 495 & 3.08 & 1334 & التقويم \\
\hline 0.61 & 2.76 & 2.65 & 495 & 2.94 & 1334 & اللارجة الكلية على المقياس العام \\
\hline
\end{tabular}

يوضح الجدول رقم ( 11) أن هناك فروقاً بين المتوسطات الحسابية لمتغير المستوى التعليمي تبعاً لمجالات

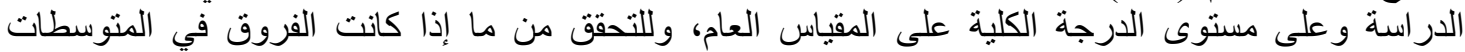

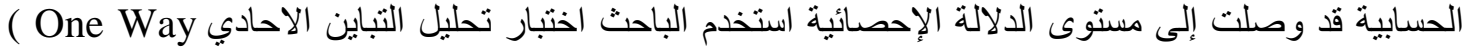

و الجدول رقم ( 12) نتائج تحليل التباين الأحادي يوضح تلك الدلالة:

\begin{tabular}{|c|c|c|c|c|c|c|c|}
\hline القرار & مستوى & قيمة f & مترسط & مربعوع الإنحرات & $\begin{array}{r}\text { الرجية } \\
\text { df } \\
\text { df }\end{array}$ & مصدر التباين & المتغير \\
\hline \multirow[t]{3}{*}{ دال } & \multirow[t]{3}{*}{0.00} & \multirow[t]{3}{*}{190.17} & 79.02 & 158.05 & 2 & بين المجمو عات & \multirow{3}{*}{ 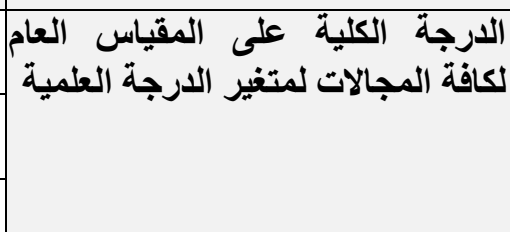 } \\
\hline & & & 0.416 & 885.54 & 2131 & داخل المجمو عات & \\
\hline & & & & 1043.59 & 2133 & المجموع & \\
\hline
\end{tabular}

يتضح من الجدول السابق أنه توجد فروق دالة إحصائياً من وجهة نظر المدراء في المدارس الحكومية تعزى

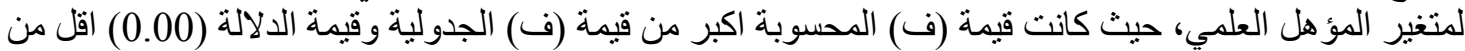

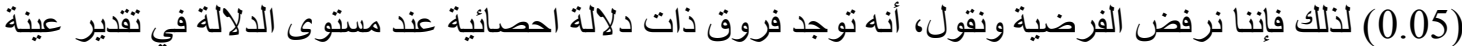
الدر اسة تعزى إلى متغير المؤهل العلمي. 


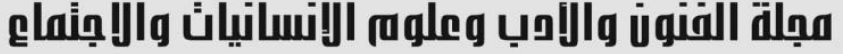

Journal of Arts, Literature, Humanities and Social Sciences www.jalhss.com

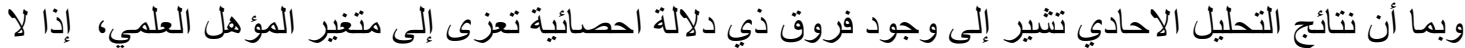

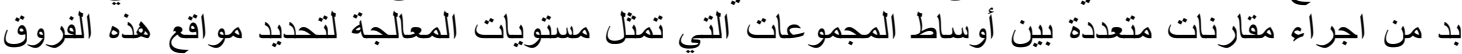
وسوف نستخدم لهذه الغاية احد مقايس المقارنات البعدية المسمى(Tukey).

جدول رقم (13) نتائج اختبار (tukey) للفروق ما بين استجابة الحاصلين على المؤهلات العلمية لارجة تحقيق

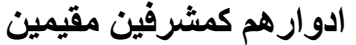

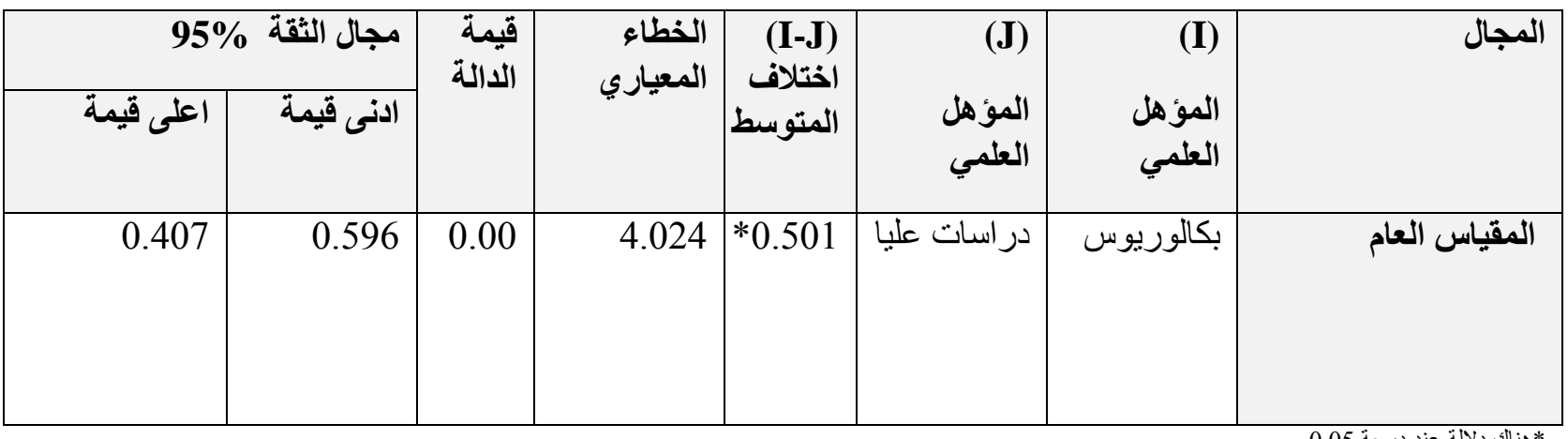

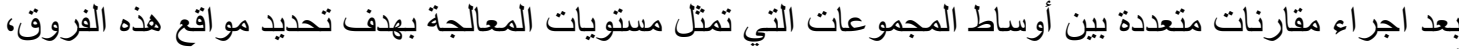

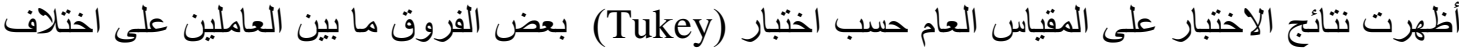

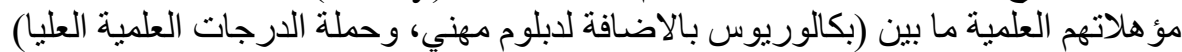

3- لا توجد فروقات ذات دلالة إحصائية عند المستوى (0.05) بين الخبرة واء الاختلاف في وجهة نظر

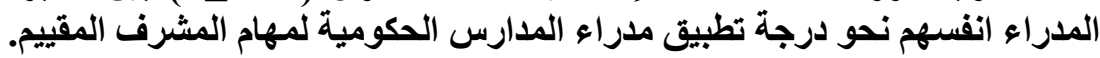

One Way من اجل فحص هذه الفرضية نم استخدام المتوسطات الحسابية واختبار تحليل التباين الأحادي)

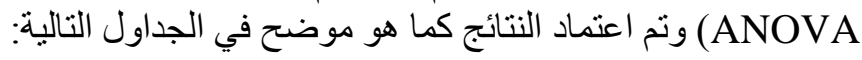

الجدول (14) المتوسطات الحسابية من وجهة نظر المدراء تبعا لمتغير سنوات الخبرة

\begin{tabular}{|c|c|c|c|c|c|c|c|c|}
\hline \multirow[t]{2}{*}{ Std.D } & \multirow{2}{*}{ اللمجلي } & \multicolumn{2}{|c|}{ اكثر من 20 سنة } & \multicolumn{2}{|c|}{ من 10 -20 سنة } & \multicolumn{2}{|c|}{ سنو من 10} & \multirow[t]{2}{*}{ المجالات } \\
\hline & & المتوسط & $\begin{array}{r}\text { العدد } \\
\text { N }\end{array}$ & المتوسط & $\begin{array}{r}\text { العدد } \\
\text { N }\end{array}$ & المتوسط & $\begin{array}{l}\text { العدد } \\
\text { N }\end{array}$ & \\
\hline 0.699 & 2.90 & 2.53 & 515 & 3.07 & 523 & 3.00 & 1096 & التخطيط \\
\hline 0.853 & 2.79 & 2.21 & 515 & 2.87 & 523 & 3.02 & 1096 & النمو المهني للمعلمين \\
\hline 0.680 & 2.84 & 2.53 & 515 & 3.00 & 523 & 2.91 & 1096 & تطوير العلاقات الانسانية \\
\hline 0.754 & 2.63 & 2.29 & 515 & 2.76 & 523 & 2.72 & 1096 & تظوير المناهج \\
\hline
\end{tabular}




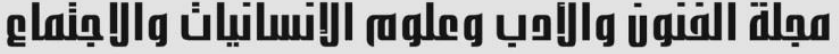

Journal of Arts, Literature, Humanities and Social Sciences www.jalhss.com

\begin{tabular}{|l|r|r|r|r|r|r|r|r|}
\hline 0.796 & 2.88 & 2.61 & 515 & 2.82 & 523 & 3.04 & 1096 & \\
\hline 0.618 & 2.76 & 2.41 & 515 & 2.88 & 523 & 2.87 & 1096 & التقييمة الكلية على المقياس العام \\
\hline
\end{tabular}

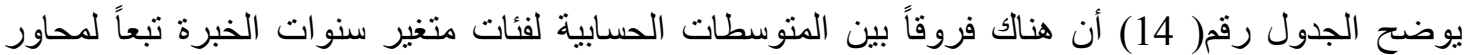

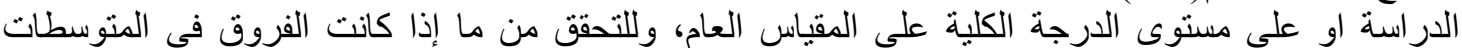

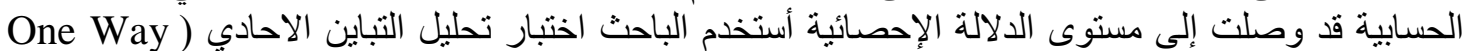

.(ANOVA

الجدول رقم ( 15) لنتائج تحليل التباين الاحادي يوضح تلك الدلالة تبعاً لمتغير سنوات الخبرة

\begin{tabular}{|c|c|c|c|c|c|c|}
\hline الدلالة & قيمة & |لمربعات & مربعات & 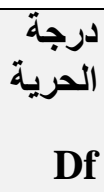 & مصدر التباين & المجالات \\
\hline \multirow[t]{3}{*}{0.00} & \multirow[t]{3}{*}{111.98} & 49.62 & 99.25 & 2 & بين المجموعات & \multirow[t]{3}{*}{ التخطيط } \\
\hline & & 0.44 & 944.34 & 2131 & داخل المجمو عات & \\
\hline & & & 1043.59 & 2133 & المجموع & \\
\hline \multirow[t]{3}{*}{0.00} & \multirow[t]{3}{*}{192.19} & 118.72 & 237.45 & 2 & بين المجموعات & \multirow[t]{3}{*}{ النمو المهني للمعلمين } \\
\hline & & 0.62 & 1316.40 & 2131 & داخل المجمو عات & \\
\hline & & & 1553.85 & 2133 & المجموع & \\
\hline \multirow[t]{3}{*}{0.00} & \multirow[t]{3}{*}{79.94} & 34.43 & 68.86 & 2 & بين المجمو عات & \multirow[t]{3}{*}{ تطوير العلاقة الانسانية } \\
\hline & & 0.43 & 917.80 & 2131 & داخل المجمو عات & \\
\hline & & & 986.66 & 2133 & المجموع & \\
\hline \multirow[t]{3}{*}{0.00} & \multirow[t]{3}{*}{71.63} & 38.20 & 76.40 & 2 & بين المجمو عات & \multirow[t]{3}{*}{ طوير المناهج } \\
\hline & & 0.53 & 1136.36 & 2131 & داخل المجمو عات & \\
\hline & & & 1212.77 & 2133 & المجموع & \\
\hline \multirow[t]{3}{*}{0.00} & \multirow[t]{3}{*}{55.42} & 33.48 & 66.96 & 2 & بين المجموعات & \multirow[t]{3}{*}{ التقييم } \\
\hline & & 0.60 & 1287.38 & 2131 & داخل المجمو عات & \\
\hline & & & 1354.35 & 2133 & المجموع & \\
\hline
\end{tabular}




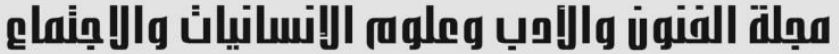

Journal of Arts, Literature, Humanities and Social Sciences www.jalhss.com

Volume (71) September 2021

العدد) (71) سبتمبر 2021

\begin{tabular}{|c|c|c|c|c|c|c|}
\hline \multirow[t]{3}{*}{0.00} & \multirow[t]{3}{*}{121.05} & 41.66 & 83.32 & 2 & بين المجموعات & \multirow[t]{3}{*}{ الارجة الكلية على المقياس العام } \\
\hline & & 0.344 & 733.36 & 2131 & داخل المجمو عات & \\
\hline & & & 816.68 & 2133 & المجموع & \\
\hline
\end{tabular}

يتضح من الجدول السابق أنه نوجد فروق دالة إحصائياً من وجهة نظر المدراء العاملين في المدارس الحكومية

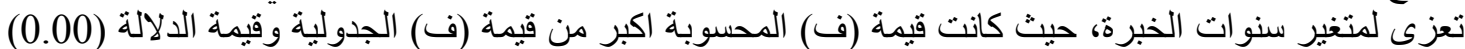

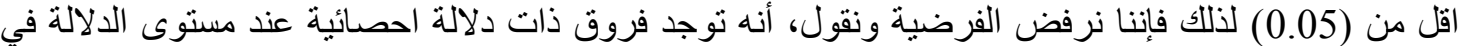
تقدير العاملين تعزى إلى متغير عدد سنو اتل نرفئ الخبرة.

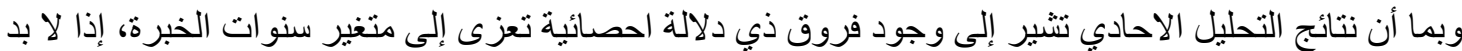

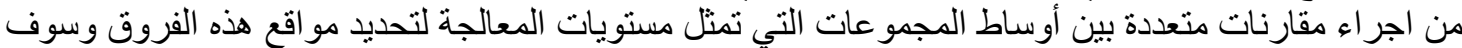
نستخدم لهذه الغاية احد مقايس المقارنات البعدية المسمى (Tukey).

جدول رقم (16) نتائج اختبار (tukey) للفروق ما بين استجابة عينة الدراسة تبعا لمتغير سنوات الخبرة لدرجة

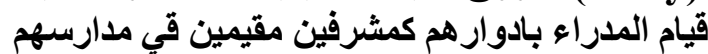

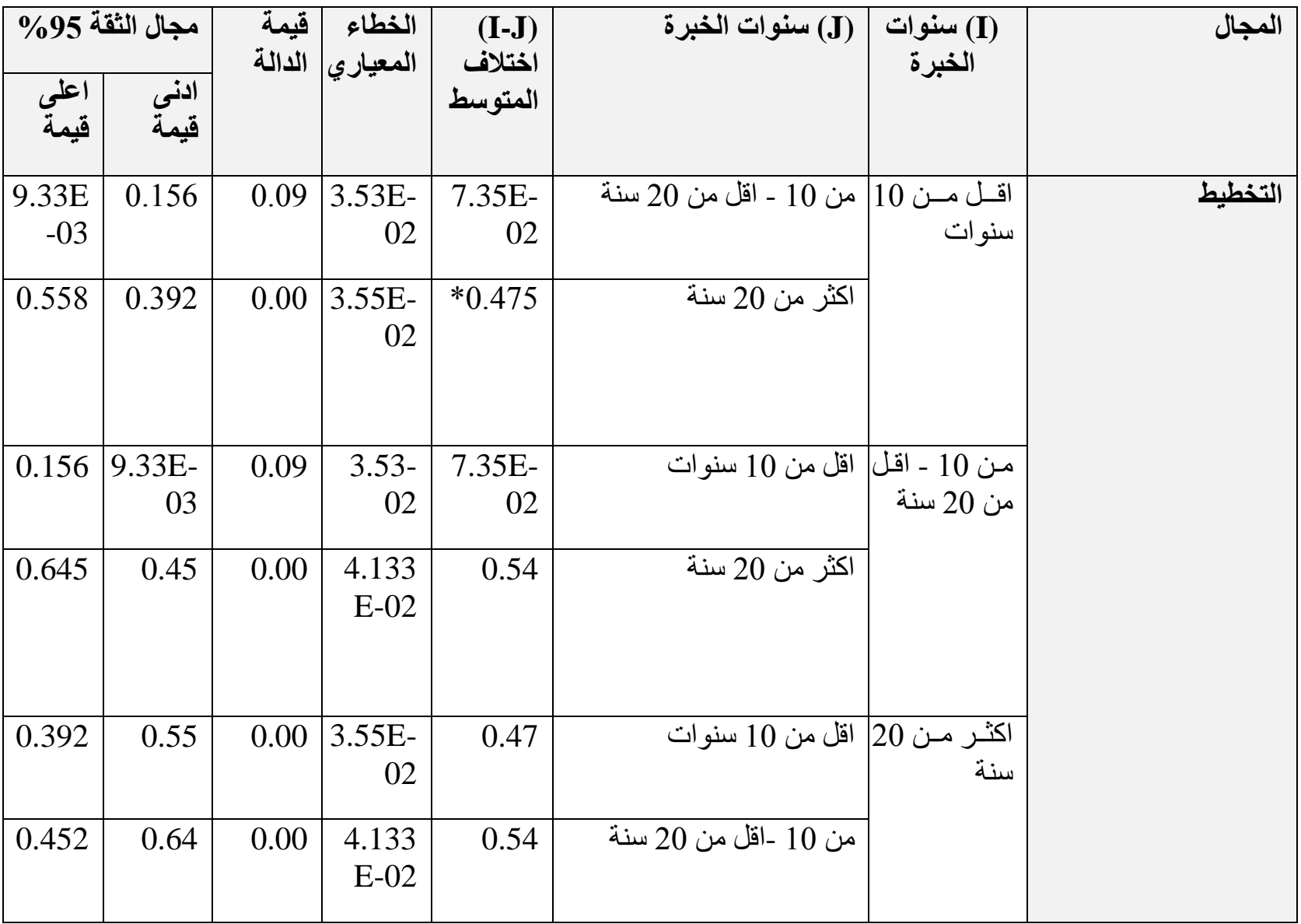




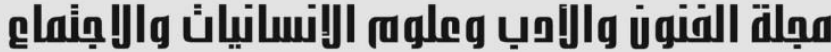

Journal of Arts, Literature, Humanities and Social Sciences www.jalhss.com

\begin{tabular}{|c|c|c|c|c|c|c|c|}
\hline 0.264 & $\begin{array}{r}5.04 \mathrm{E}- \\
02\end{array}$ & 0.00 & $\begin{array}{r}4.17 \mathrm{E}- \\
02\end{array}$ & 0.14 & من 10 ـاقل من 20 سنة & سنوات مــن 10 & النمو المهني للمعلمين \\
\hline 0.913 & 0.71 & 0.00 & $\begin{array}{r}4.19 \mathrm{E}- \\
02\end{array}$ & 0.81 & اكثر من 20 سنة & & \\
\hline $\begin{array}{r}5.04 \mathrm{E} \\
-02\end{array}$ & 0.24 & 0.00 & $\begin{array}{r}4.17 \mathrm{E}- \\
02\end{array}$ & 0.14 & اقل من 10 سنو ات & من 20 سنة - اقل & \\
\hline 0.780 & 0.55 & 0.00 & $\begin{array}{r}4.87 \mathrm{E}- \\
02\end{array}$ & 0.66 & اكثر من 20 سنة & & \\
\hline 0.716 & 0.91 & 0.00 & $\begin{array}{r}4.19 \mathrm{E}- \\
02\end{array}$ & 0.81 & اقل من 10 سنوات & سنة اكتر مسن 20 & \\
\hline 0.551 & 0.78 & 0.00 & $\begin{array}{r}4.87 \mathrm{E}- \\
02\end{array}$ & 0.66 & من 10 ـاقل من 20 سنة & & \\
\hline $\begin{array}{r}6.92 \mathrm{E} \\
-02\end{array}$ & 0.17 & 0.03 & $\begin{array}{r}3.48 \mathrm{E}- \\
02\end{array}$ & $\begin{array}{r}8.86 \mathrm{E} 0 \\
2\end{array}$ & من 10 ـاقل من 20 سنة & 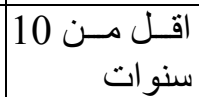 & تطوير العلاقة الانساتية \\
\hline 0.464 & 0.30 & 0.00 & $\begin{array}{r}3.50 \mathrm{E}- \\
02\end{array}$ & 0.38 & اكثر من 20 سنة & & \\
\hline 0.170 & $\begin{array}{r}6.92 \mathrm{E}- \\
03\end{array}$ & 0.03 & $\begin{array}{r}3,48 \mathrm{E}- \\
02\end{array}$ & $\begin{array}{r}8.86 \mathrm{E}- \\
02\end{array}$ & اقل من 10 سنوات & 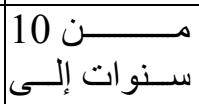 & \\
\hline 0.566 & 0.37 & 0.00 & $\begin{array}{r}4.07 \mathrm{E}- \\
02\end{array}$ & 0.47 & اكثر من 20 سنة & سنة & \\
\hline 0.300 & 0.46 & 0.00 & $\begin{array}{r}3.50 \mathrm{E}- \\
02\end{array}$ & 0.38 & اقل من 10 سنوات & سنة اكثر مـن 20 & \\
\hline 0.375 & 0.56 & 0.00 & $\begin{array}{r}4.07 \mathrm{E}- \\
02\end{array}$ & 0.47 & من سنة 10 سنو ات إلى اقل من & & \\
\hline $\begin{array}{r}5.45 \mathrm{E} \\
-02\end{array}$ & 0.12 & 0.61 & $\begin{array}{r}3.88 \mathrm{E}- \\
02\end{array}$ & $\begin{array}{r}3.64 \mathrm{E}- \\
02\end{array}$ & 20 سنة 10 سـنوات إلى اقل مـن & 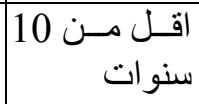 & تطوير المناهج \\
\hline 0.520 & 0.33 & 0.00 & $\begin{array}{r}3.90 \mathrm{E}- \\
02\end{array}$ & 0.42 & اكثر من 20 سنة & & \\
\hline 0.127 & $5.45 \mathrm{E}-$ & 0.61 & $3.88 \mathrm{E}-$ & $3.64 \mathrm{E}-$ & اقل من 10 سنو ات & 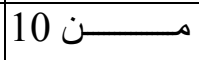 & \\
\hline
\end{tabular}




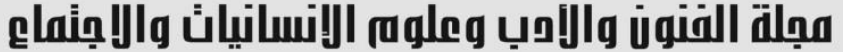

Journal of Arts, Literature, Humanities and Social Sciences www.jalhss.com

Volume (71) September 2021

العدد(71) سبتمبر 2021

\begin{tabular}{|c|c|c|c|c|c|c|c|}
\hline & 02 & & 02 & 02 & & 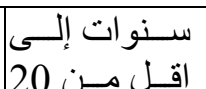 & \\
\hline 0.571 & 0.35 & 0.00 & $\begin{array}{r}4.53 \mathrm{E}- \\
02\end{array}$ & 0.46 & اكثر من 20 سنة & سنة ماسة & \\
\hline 0.337 & 0.52 & 0.00 & $\begin{array}{r}3.90 \mathrm{E}- \\
02\end{array}$ & 0.42 & اقل من 10 سنوات & سنة & \\
\hline 0.359 & 0.57 & 0.00 & $\begin{array}{r}4.53 \mathrm{E}- \\
02\end{array}$ & 0.46 & من 10 سنوات إلى اقل من & & \\
\hline 0.319 & 0.12 & 0.00 & $\begin{array}{r}4.13 \mathrm{E}- \\
02\end{array}$ & 0.22 & 20 سنة 10 سنوات إلى اقل مـن & سنوات مـن 10 اقـل & التقييم \\
\hline 0.524 & 0.33 & 0.00 & $\begin{array}{r}4.15 \mathrm{E}- \\
02\end{array}$ & 0.42 & اكثر من 20 سنة & & \\
\hline 0.125 & 0.31 & 0.00 & $\begin{array}{r}4.13 \mathrm{E}- \\
02\end{array}$ & 0.22 & اقل من 10 سنو ات & 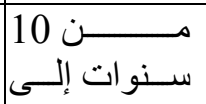 & \\
\hline 0.318 & $\begin{array}{r}9.19 \mathrm{E}- \\
02\end{array}$ & 0.00 & $\begin{array}{r}4.82 \mathrm{E}- \\
02\end{array}$ & 0.20 & اكثر من 20 سنة & 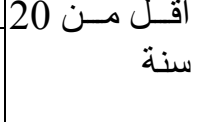 & \\
\hline 0.330 & 0.52 & 0.00 & $\begin{array}{r}4.15 \mathrm{E}- \\
02\end{array}$ & 0.42 & اقل من 10 سنو ات & سنة اكثر مـن 20 & \\
\hline $\begin{array}{r}9.19 \mathrm{E} \\
-02\end{array}$ & 0.31 & 0.00 & $\begin{array}{r}4.83 \mathrm{E}- \\
02\end{array}$ & 0.20 & من سنة 10 سنو ات إلى اقل من & & \\
\hline 6.79 & 7.82 & 0.98 & 3.11 & 5.144 & مـن 10 سـنوات إلى اقل مـن & اقـل مـن 10 & المقياس العام حسب \\
\hline E-02 & E-02 & & E-02 & E-03 & & 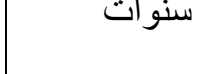 & Tukey ختبار \\
\hline 0.533 & 0.38 & 0.00 & 3.13 & $* 0.460$ & اكثر من 20 سنة & & \\
\hline & & & E-02 & & & & \\
\hline 7.821 & 6.79 & 0.98 & 3.11 & 5.144 & اقل من 10 سنو ات & 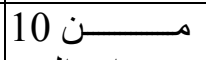 & \\
\hline & E-02 & & E-02 & E-03 & & & \\
\hline 0.550 & 0.379 & 0.00 & 3.642 & $* 0.465$ & اكثر من 20 سنة & & \\
\hline 0.386 & 0.533 & 0.00 & $\begin{array}{l}3.134 \\
\text { E-02 }\end{array}$ & $* 0.460$ & اقل من 10 سنو ات & سنة & \\
\hline 0.379 & 0.550 & 0.00 & 3.642 & 0.465 & من 10 سنوات إلى اقل من & & \\
\hline
\end{tabular}




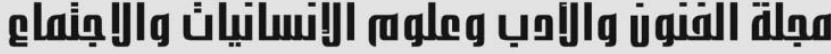

Journal of Arts, Literature, Humanities and Social Sciences www.jalhss.com

\begin{tabular}{|l|l|r|l|r|r|l|}
\hline & & E-02 & & 20 & & \\
\hline
\end{tabular}

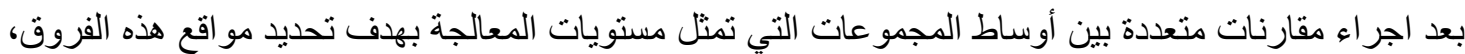

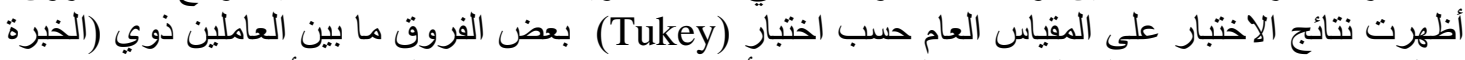

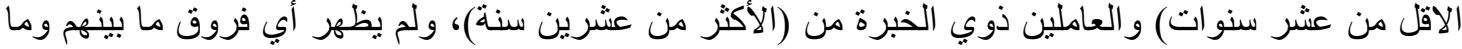
بين العاملين ذوي (الخبرة من عشر سنو ات إلى عشئ عشرين سنة).

اما بشكل تفصلي فإن النتائج اشارت إلى وجود فروق تعود إلى التخطيط ما بين العاملين من ذوبي (الخبرة الاقل

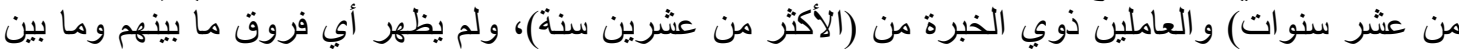
العاملين ذوي (الخبرة من عشر سنوات إلى عشرين سنة).

اما في مجال (النمو المهني، وتطوير العلاقات الانسانبة وتطوير المناهج) )فإنه لم يظهر أب فروق اخرى دالة.

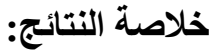

1- أن درجة تقدير واقع تطبيق الإدارة المدرسية لدوره كمشرف مقيم من خلال تطبيق مجالات الدرسة

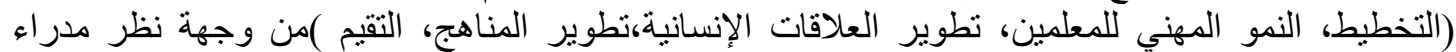
المدارس الحكومية انفسهم كانت قليلة.

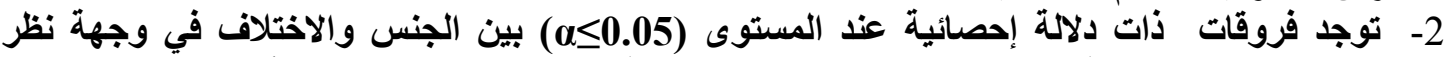

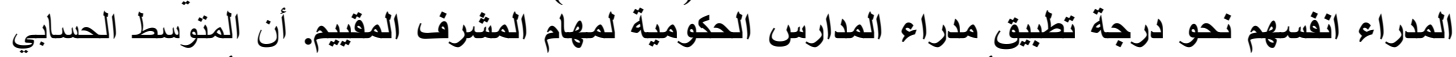

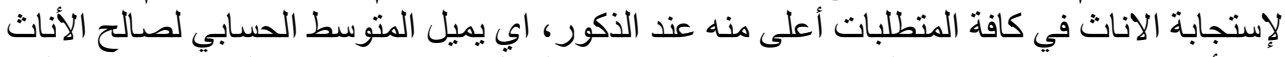
3- أنه توجد فروق ذات دلالة احصائية عند مستوى الدلالة في تقدير عينة الدراسة تعزى إلى متغير المؤهل

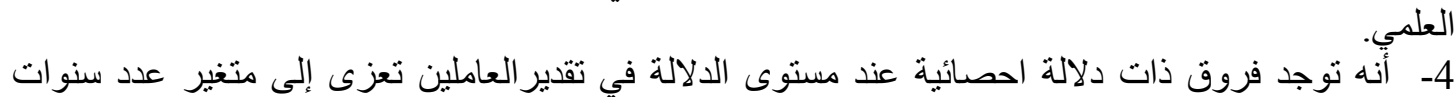

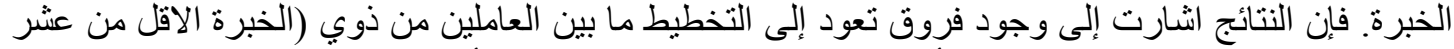

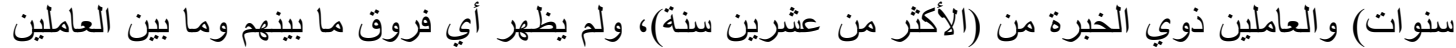
ذوي (الخبرة من عشر سنو الت إلى عشرين سنة).

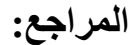

1- أبو كثنك، داعس.(2009). دور مدير المدرسة كمشرف مقيم و أثره في تحسين العملية التربوية .المؤتمر

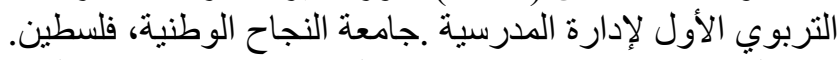

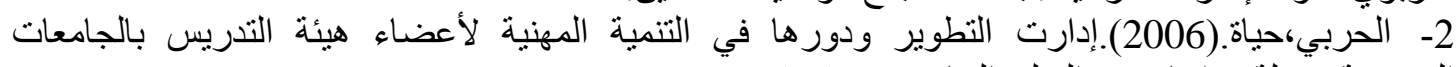

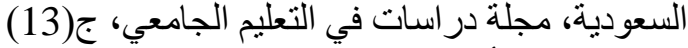
3- القر عان، أحمد خليل وحر احشة، إبر اهيم " محمد علي (13) 2004 ) "الإدارة المدرسية. الحديثة .دار الإسراء

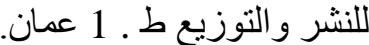
4- القاسم ،منصور(2010).درجة ممارسة مديري المدارس الثانوية في الاردن لدورهم كمشرفين مقيمين،

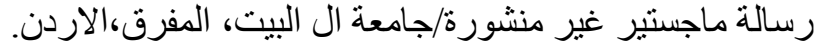

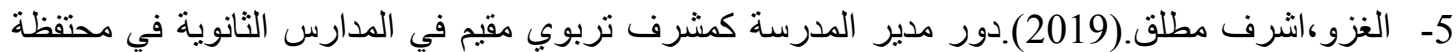

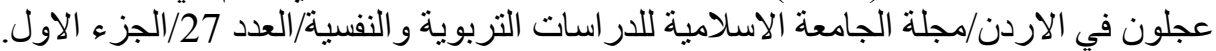

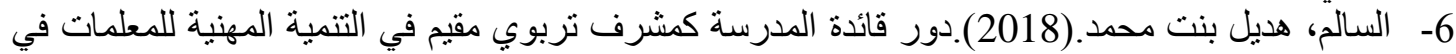
مدينة الرياض/مجلة كلية التربية/جامعة الاز هر /العدد 178 الجزء العدر الاول. 


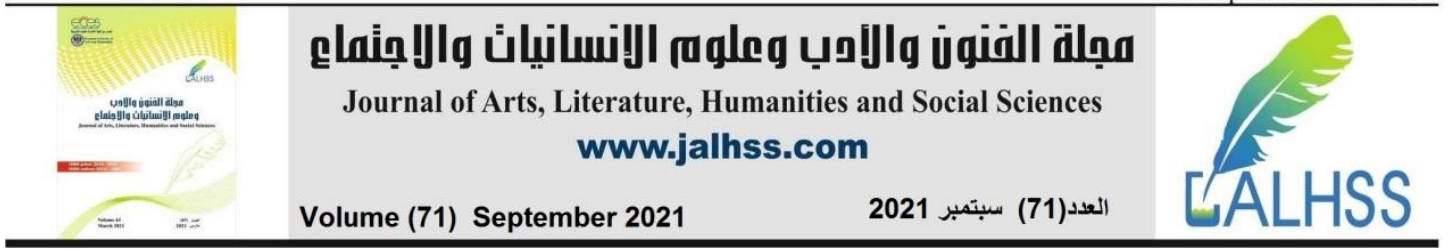

7- العجمي،سلطان محمد(2014)."درجة ممارسة مديري المدارس الثنانوية في الاردن لدور هم كمشرفين

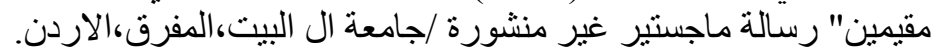

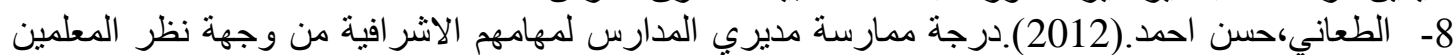
في الاردن/ مجلة جامعة دمشق/المجلد 28 العمدة العدد الثاني.

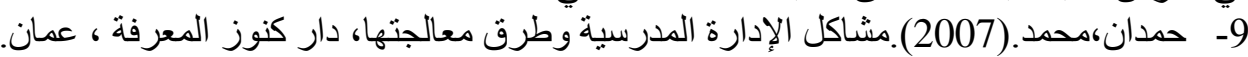

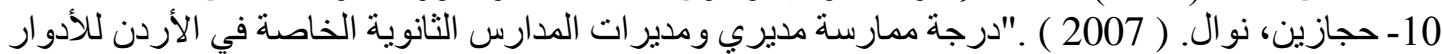
الإشر افية من وجهة نظر المعلمين"،رسالة ماجستيرغير منشورة، جامعة عمان العربية للار اسات العليا عمان

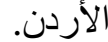
11- حسان، حسن محمد، العجمي، محمد حسنين ( 2007 ) الإدارة التربوية . دار ـ المسيرة للنشر و التوزيع ـ ط 1. 1 . عمان.

12- حسين، سلامة وأبو الوفا، جمال ـ( 2008 ) الإدارة المدرسية والصفية .الإسكندرية :دار الجامعة الجديدة.

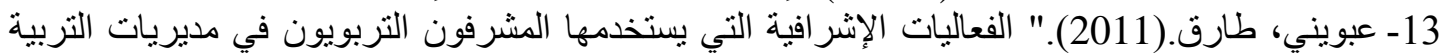

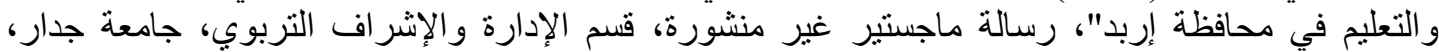

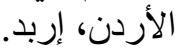

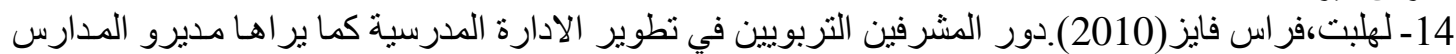

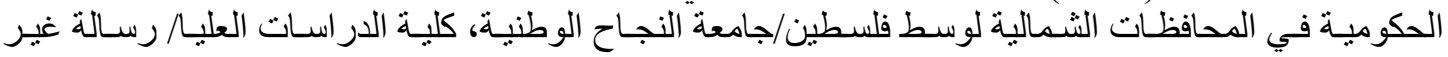

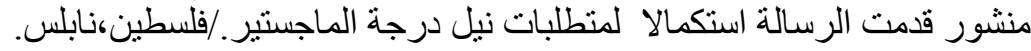

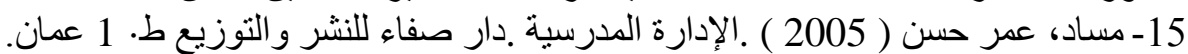

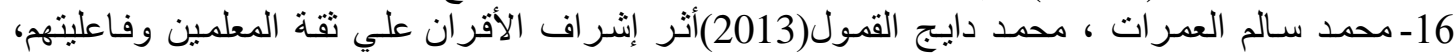

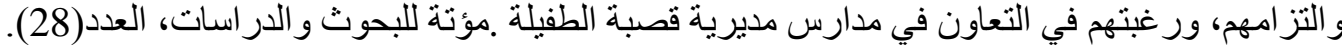

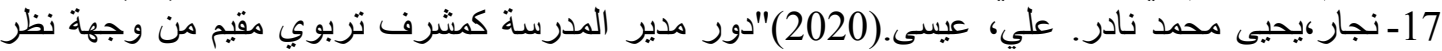
المعلمين في مدينة دمشق" مجلة جامعة حماة /المجلد الثالث /العدد السابع عشر.

\section{References}

1- Abu Kishk, Da'is (2009). The role of the school principal as a resident supervisor and its impact on improving the educational process. The first educational conference for school management. An-Najah National University, Palestine.

2- Al-Harbi, Hayat. (2006). Development management and its role in the professional development of faculty members in Saudi universities, Journal of Studies in University Education, vol. (13)

3- Al-Quran, Ahmed Khalil and Harahsheh, Ibrahim "Muhammad Ali" (2004) School Administration. modern. Dar Al-Israa for Publishing and Distribution, 1st floor. Oman.

4- Al-Qassem, Mansour (2010). The degree to which secondary school principals in Jordan practice their role as resident supervisors, unpublished master's thesis, Al alBayt University, Mafraq, Jordan.

5- The invasion, Ashraf Mutlaq. (2019). The role of the school principal as a resident educational supervisor in secondary schools in Ajloun Governorate in Jordan / Journal of the Islamic University for Educational and Psychological Studies / Issue 27 / Part One.

6- Al-Salem, Hadeel bint Muhammad. (2018). The role of the school leader as a resident educational supervisor in the professional development of female teachers in the city of Riyadh / Journal of the College of Education / Al-Azhar University / Issue 178 Part One. 


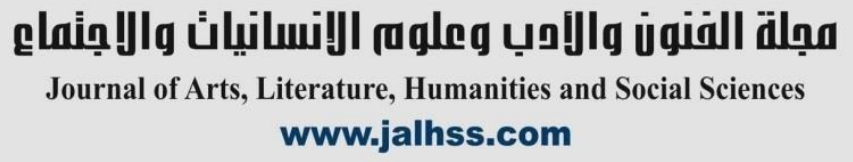

7- Al-Ajmi, Sultan Muhammad (2014). "The degree of secondary school principals in Jordan's practice of their role as resident supervisors." Unpublished master's thesis, Al al-Bayt University, Mafraq, Jordan.

8- Al-Taani, Hassan Ahmed. (2012). The degree of school principals exercising their supervisory duties from the point of view of teachers in Jordan / Damascus University Journal / Volume 28, second issue.

9- Hamdan, Muhammad. (2007). School administration problems and ways to address them, Kunooz al-Maarifa House, Amman.

10- Hijazin, Nawal. (2007) "The degree to which private secondary school principals in Jordan practice supervisory roles from the teachers' point of view", an unpublished master's thesis, Amman Arab University for Graduate Studies, Amman, Jordan.

11- Hassan, Hassan Muhammad, Al-Ajmi, Muhammad Hassanein (2007) Educational Administration. Dar Al-Masira for Publishing and Distribution. i 1 . Oman.

12- Hussein, Salama and Abu Al-Wafa, Jamal (2008). School and classroom management. Alexandria: New University House.

13- Abweni, Tariq. (2011). "Supervisory Activities Used by Educational Supervisors in the Directorates of Education in Irbid Governorate", an unpublished master's thesis, Department of Educational Administration and Supervision, Jedar University, Jordan, Irbid.

14- Lahlabt, Firas Fayez (2010). The role of educational supervisors in developing school administration as seen by the principals of public schools in the northern governorates of central Palestine / An-Najah National University, College of Graduate Studies / unpublished thesis. The thesis was submitted to complete the requirements for obtaining a master's degree. / Palestine, Nablus.

15- Massad, Omar Hassan. (2005) School Administration. Dar Safaa for Publishing and Distribution, 1st floor, Amman.

16- Muhammad Salem Al-Amrat and Muhammad Dayej Al-Qumoul (2013) The impact of peer supervision on teachers' trust, effectiveness, commitment, and willingness to cooperate in the schools of the Kasbah of Tafila district. Mutah for Research and Studies, Issue (28).

17- Carpenter, Yahya Muhammad Nader. Ali, Issa. (2020) "The role of the school principal as a resident educational supervisor from the point of view of teachers in the city of Damascus." Hama University Journal / Volume Three / Issue Seventeen. 